\title{
MODEL PESANTREN RAKYAT AL-AMIN DI SUMBERPUCUNG KABUPATEN MALANG
}

\section{TESIS}

Diajukan kepada Program Magister Pendidikan Agama Islam Sekolah Pascasarjana Universitas Islam Negeri Maulana Malik Ibrahim Malang Pada Semester Genap Tahun Akademik 2013/2014

Oleh :

I'ANATUT THOIFAH

NIM: 11770034

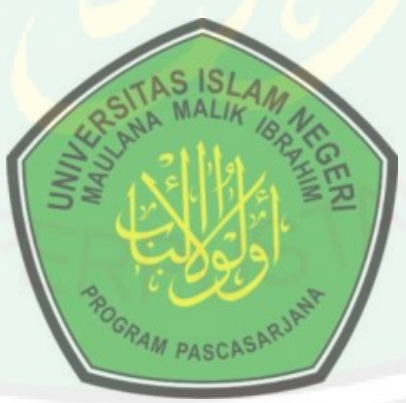

PROGRAM MAGISTER PENDIDIKAN AGAMA ISLAM

SEKOLAH PASCASARJANA

UNIVERSITAS ISLAM NEGERI MAULANA MALIK IBRAHIM MALANG

Mei, 2013 


\title{
MODEL PESANTREN RAKYAT AL-AMIN DI SUMBERPUCUNG KABUPATEN MALANG
}

\begin{abstract}
TESIS
Diajukan kepada Program Magister Pendidikan Agama Islam Sekolah Pascasarjana Universitas Islam Negeri Maulana Malik Ibrahim Malang Pada Semester Genap Tahun Akademik 2013/2014
\end{abstract}

Oleh :

I'ANATUT THOIFAH

NIM: 11770034

Pembimbing:

Dr. H. Munirul Abidin, M.Ag

Dr. H. Zulfi Mubarag, M.Ag

NIP. 197204202002121003 NIP. 197310172000031001

PROGRAM MAGISTER PENDIDIKAN AGAMA ISLAM

SEKOLAH PASCASARJANA

UNIVERSITAS ISLAM NEGERI MAULANA MALIK IBRAHIM MALANG

Mei, 2013 


\section{LEMBAR PERSETUJUAN UJIAN TESIS}

Tesis dengan judul Model Pesantren Rakyat Al-Amin di Sumberpucung Kabupaten Malang telah diperiksa dan disetujui untuk diuji.

Malang, 19 April 2013

Pembimbing I

Dr. H. Munirul Abidin, M.Ag

NIP. 197204202002121003

Pembimbing II

Dr. H. Zulfi Mubarag, M.Ag

NIP. 197310172000031001

Mengetahui

Ketua Program Studi PAI,

Dr. H. Rasmianto, M.Ag

NIP. 197012311998031001 


\section{LEMBAR PENGESAHAN}

Tesis dengan judul Model Pesantren Rakyat Al-Amin di Sumberpucung Kabupaten Malang ini telah diuji dan dipertahankan di depan sidang dewan penguji pada tanggal 29 April 2013.

Dewan Penguji,

Drs. Fadil , M.Ag

Ketua

NIP. 196512311992031046

Dr. H. M. Samsul Hady, M.Ag

Penguji Utama

NIP. 196608251994031002

Dr. H. Munirul Abidin, M.Ag NIP. 197204202002121003

Anggota

Dr. H. Zulfi Mubarag, M.Ag

NIP. 197310172000031001

Anggota

Mengetahui,

Direktur Program Sekolah Pascasarjana

Prof. Dr. H. Muhaimin, M.A

NIP. 195612111983031005 


\section{SURAT PERNYATAAN ORISINALITAS PENELITIAN}

Dengan ini yang bertanda tangan di bawah ini:

Nama

: I'anatut Thoifah, S.Pd.I

NIM

: 11770034

Program Studi

: Pendidikan Agama Islam (PAI)

Alamat

Dk. Singkil, Ds. Mentoro, Kec. Soko -Tuban

Judul Penelitian

: Model Pesantren Rakyat Al-Amin di Sumberpucung Kabupaten Malang)

Menyatakan dengan sebenarnya bahwa dalam hasil penelitian saya ini tidak terdapat unsur-unsur penjiplakan karya penelitian atau karya ilmiah yang pernah dilakukan atau dibuat oleh orang lain, kecuali yang secara tertulis dikutip dalam naskah ini dan disebutkan dalam sumber kutipan dan daftar pustaka.

Apabila dikemudian hari ternyata hasil penelitian ini terbukti terdapat unsur-unsur penjiplakan dan ada klaim dari pihak lain, maka saya bersedia untuk diproses sesuai peraturan perundang-undangan yang berlaku.

Demikian surat pernyataan ini saya buat dengan sebenarnya dan tanpa paksaan dari siapapun.

Malang, 22 April 2013

Hormat saya,

I'anatut Thoifah, S.Pd.I

11770034 


\section{KATA PENGANTAR}

Alhamdulillah, puji syukur kehadirat Allah SWT yang telah menciptakan langit dihiasi bulan yang menerangi kegelapan malam, menciptakan bumi dengan berbagai hasil tambang serta Rahmat, Taufiq, dan Hidayah yang telah diberikan oleh-Nya disetiap detik yang tidak terhitungkan. Shalawat beriringkan salam marilah kita sampaikan kepada seorang pemuda padang pasir yang miskin akan hartanya tapi kaya akan ilmunya. Beliau merupakan putra kesayangan Abdullah buah hati Aminah. Pemimpin pujaan yang menjadi tauladan. Pemuda pilihan dengan akhlak yang menawan. Tak dapat terbantahkan bahwa beliau seorang pembawa risalah yang membawa amanah, dan tetap istiqamah dalam ibadah yakni Nabi besar Muhammad SAW. Selanjutnya, penulis mengucapkan rasa terima kasih kepada pihak-pihak yang terlibat langsung maupun tidak langsung dalam terselesaikannya skripsi ini, di antara mereka adalah:

1. Bapak Prof. Dr. H. Mudjia Raharjo, M.Si UIN Maulana Malik Ibrahim Malang.

2. Bapak Prof. Dr. H. Muhaimin, MA. Selaku Direktur Sekolah Pascasarjana UIN Maulana Malik Ibrahim Malang.

3. Bapak Dr. H. Rasmianto, M.Ag. Selaku Ketua Prodi Magister Pendidikan Agama Islam UIN Maulana Malik Ibrahim Malang.

4. Bapak Dr. H. Munirul Abidin, M.Ag dan Bapak Dr. H. Zulfi Mubarag, M.Ag Selaku dosen pembimbing yang telah mencurahkan semua pikiran dan waktunya untuk memberikan arahan dan bimbingan bagi penulisan tesis ini. 
5. Bapak dan Ibu tercinta yang selalu memberikan yang terbaik dan berjuang yang tak kenal lelah buat penulis.

6. Ust. Abdullah Sam, S.Psi (Ca' Dolah) beserta seluruh tenaga pendidik dan santri di Pesantren Rakyat yang telah memberi dukungan dan bantuan dalam proses penelitian.

7. Semua guru-guru, dosen-dosen, yang selama ini memberikan ilmunya pada penulis untuk kecerahan masa depan.

8. Sahabat-sahabatku Sekolah Pascasarjana yang telah memberikan dukungan dan curahan motivasi tinggi kepada penulis.

9. Seluruh Dewan Pengasuh, Murabbi/ah, dan teman-teman Musyrif/ah, Mahasantri Ma'had Jami'ah Sunan Ampel Al-Aly UIN Maulana Malik Ibrahim Malang atas segala Do'a dan semangat tak pernah henti. Terima kasih.

Sebagai manusia yang tak pernah luput dari kesalahan. Karena itu penulis mengharapkan saran dan kritik yang bersifat membangun. Semoga tesis ini bermanfaat bagi penulis dan pembaca. Amiin.

Malang, 22 April 2013

\section{Penulis}




\section{DAFTAR ISI}

\section{COVER DEPAN}

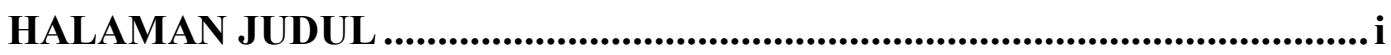

PERSETUJUAN PEMBIMBING ...........................................................ii

PENGESAHAN PENGUJI.......................................................................... iii

PERNYATAAN KEASLIAN TESIS .................................................. iv

KATA PENGANTAR .............................................................................. v

DAFTAR ISI $\quad$....................................................................................... vii

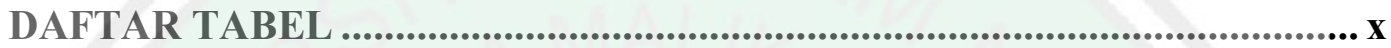

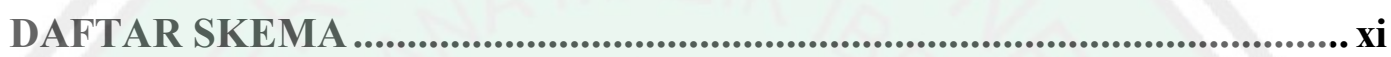

DAFTAR GAMBAR................................................................................ xii

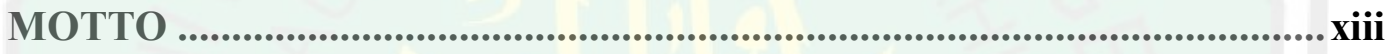

ABSTRAK BAHASA INDONESIA ......................................................... xiv

ABSTRAK BAHASA INGGRIS .............................................................. xvi

ABSTRAK BAHASA ARAB...................................................................... xviii

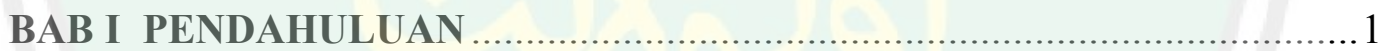

A. Konteks Penelitian........................................................................... 1

B. Fokus Penelitian..................................................................4

C. Tujuan Penelitian .................................................................. 4

D. Manfaat Penelitian.......................................................................5

E. Originalitas Penelitian ...................................................................6 6

F. Definisi Istilah .......................................................9

BAB II KAJIAN PUSTAKA $\ldots \ldots \ldots \ldots \ldots \ldots \ldots \ldots \ldots \ldots \ldots \ldots \ldots \ldots \ldots \ldots \ldots \ldots \ldots \ldots \ldots \ldots \ldots \ldots$

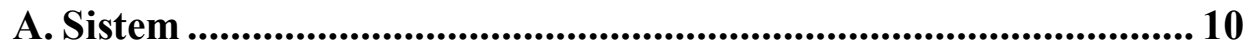

1. Pengertian sistem ............................................................. 10

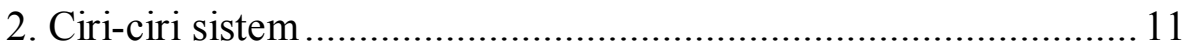

3. Tujuan sistem................................................................ 12

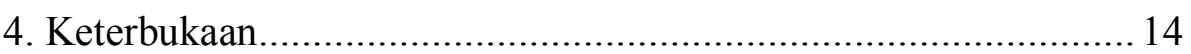

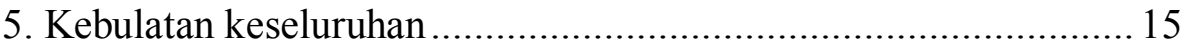


B. Pesantren.............................................................................................. 17

1. Pengertian pesantren ................................................................. 17

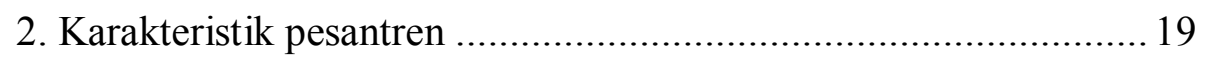

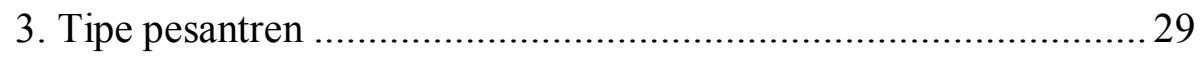

4. Kurikulum pesantren............................................................... 35

5. Metode dan sistem pengajaran di pesantren............................... 37

6. Perkembangan dan perubahan kurikulum dan metode ................. 38

7. Keterpaduan dalam sistem pendidikan keIslaman, keIndonesiaan,

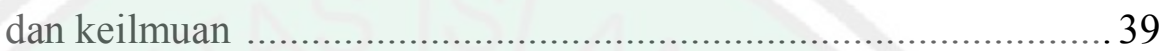

BAB III METODE PENELITIAN ...........................................................51

A. Pendekatan dan Jenis Penelitian.................................................... 51

B. Kehadiran Peneliti...............................................................5 52

C. Lokasi Penelitian.........................................................................5 54

D. Data dan Sumber Data ....................................................55

E. Teknik Pengumpulan Data................................................56

F. Teknik Analisis Data ......................................................63

G. Pengecekan Keabsahan Temuan............................................ 67

BAB IV PAPARAN DATA DAN TEMUAN PENELITI ............................ 71

A. Gambaran Umum Pesantren Rakyat Sumberpucung Kabupaten Malang 71

1. Diskripsi Lokasi Penelitian ........................................................ 71

a. Sejarah Berdirinya Pesantren Rakyat Sumberpucung Malang... 71

b. Visi, Misi dan Tujuan........................................................ 73

c. Bidang atau Sasaran ........................................................... 74

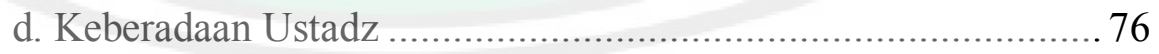

e. Sarana dan Prasarana ............................................................... 76

B. Pesantren Rakyat Al-Amin ......................................................... 77

1. Model Pesantren Rakyat Al-Amin............................................... 77

2. Komponen Pesantren di Pesantren Rakyat Al-Amin.................... 81

BAB V DISKUSI HASIL PENELITIAN ...............................................99

Model Pesantren Rakyat Al-Amin Sumberpucung Kabupaten

Malang .......................................................................................... 97 


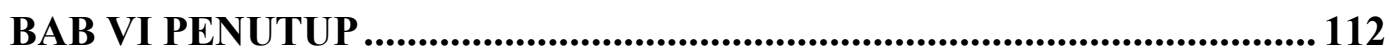

A. Kesimpulan .......................................................................... 112

B. Saran ..................................................................................... 114

DAFTAR PUSTAKA

DAFTAR RIWAYAT HIDUP 


\section{DAFTAR TABEL}

Tabel

HIm

Tabel 2.1 4 Kriteria untuk memilih penting atau tidaknya suatu tujuan.............. 13

Tabel 3.1 Dokumentasi yang diperlukan dalam penelitian ..............................6 62

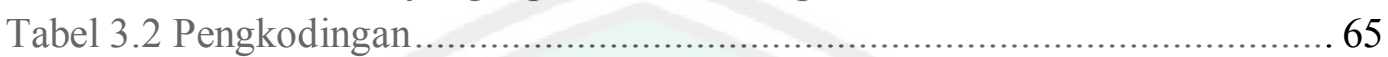

Tabel 4.1 Daftar Nama Ustadz Pesantren Rakyat A1-Amin............................. 76

Tabel 4.2 Sarana dan Prasarana Pesantren Rakyat Al-Amin ............................ 77

Tabel 4.3 Macam Kegiatan Pesantren Rakyat Al-Amin.................................. 90 


\section{DAFTAR SKEMA}

Skema

HIm

Skema 2.1 Empat Komponen Pesantren Menurut Manfred Ziemek................... 19

Skema 2.2 Lima Komponen Pesantren Menurut Zamakhsyari Dhofier.............. 20

Skema 2.3 Alasan Adanya Asrama/Pondok.................................................... 21

Skema 2.4 Fungsi Masjid ..................................................................... 22

Skema 2.5 Pengajaran Kitab Klasik .......................................................... 24

Skema 2.6 Pembagian Macam-macam Santri ................................................. 26

Skema 2.7 Peran Kiai di Pesantren.............................................................. 28

Skema 2.8 Tipologi Pesantren................................................................ 35

Skema 2.9 Corak dan Istilah-istilah Baru Pesantren...................................... 35

Skema 3.1 Fokus Penelitian ................................................................... 56

Skema 3.2 Langkah-langkah Analisis Data ................................................. 66

Skema 4.1 Model "Pondok" di Pesantren Rakyat Al-Amin ............................ 83

Skema 4.2 Sistem "Masjid" di Pesantren Rakyat Al-Amin ............................... 86

Skema 4.3 Model "Pengajaran Kitab Klasik" di Pesantren Rakyat Al-Amin....... 89

Skema 4.4 Makna Santri Pesantren Rakyat Al-Amin..................................... 92

Skema 4.5 Macam-macam Santri Pesantren Rakyat Al-Amin ......................... 92

Skema 4.6 Peran Kiai di Pesantren Rakyat Al-Amin ..................................... 96

Skema 5.1 Empat Komponen Pesantren Menurut Manfred Ziemek.................. 98

Skema 5.2 Lima Komponen Pesantren Menurut Zamakhsyari Dhofier.............. 98

Skema 5.3 Komponen Pesantren Rakyat Al-Amin ......................................... 99

Skema 5.4 Model "Pondok" di Pesantren Rakyat Al-Amin ........................... 100

Skema 5.5 Model "Masjid" di Pesantren Rakyat Al-Amin ............................ 103

Skema 5.6 Model "Pengajaran Kitab Klasik”Pesantren Rakyat Al-Amin ........ 105

Skema 5.7 Model "Santri”" Pesantren Rakyat Al-Amin................................. 108

Skema 5.8 Model "Kiai”" di Pesantren Rakyat Al-Amin ............................... 110 


\section{DAFTAR GAMBAR}

\section{Gambar}

Gambar 3.1 Komponen-komponen Analisis Data: Model Alir 64

Gambar 4.1 Kesederhanaan Rumah Kiai Pesantren Rakyat Al-Amin 80

Gambar 4.2 Santri "Inti” di Dalam Pondok Sederhana Pesantren Rakyat Al-Amin 80

Gambar 4.3 Banner Pesantren Rakyat Al-Amin 80

Gambar 4.4 Santri Berprestasi yang Akan Melanjutkan ke Pendidikan AKMIL80 Gambar 4.5 Salah Satu Strategi Pengajaran Pesantren Rakyat Gong-gongan........

"Jagong Maton" 89

Gambar 4.6 Salah Satu Kegiatan Ekonomi "Jualan Lumut" .89

Gambar 4.7 Kegiatan Mengajinya Santri Inti Selayaknya Santri di Pondok Pesantren.

Gambar 4.8 Strategi Pendekatan dan Penanaman Keyakinan Kepada Santri Pendukung. .89

Gambar 4.9 Gaya Kesederhanaan dan Keunikan Kiai Pesantren Rakyat Al-Amin .95

Gambar 4.10 Strategi Da’wah Kiai Pesantren Rakyat Al-Amin dengan Gonggongan "Jagong Maton". .95 


\section{MOTTO}

\section{My Life My Choice}

Aku ada karena aku memberi pengaruh Aku ada karena aku memberi makna bagi kehidupan

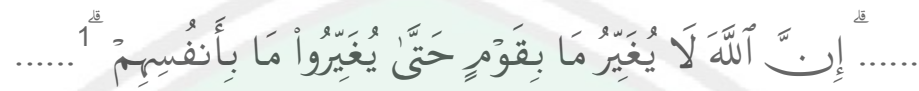

(QS. Ar-Ra'd (13): 11)

"Sesungguhnya Allah tidak merubah keadaan sesuatu kaum sehingga mereka merubah keadaan yang ada pada diri mereka sendiri”.

${ }^{1}$ Muhammad Shohib. T, Al-Qur'an Terjemah Paralel Indonesia Inggris (Solo: Al-Qur'an Qamari, 2010), hlm. 250 


\begin{abstract}
ABSTRAK
Thoifah, I'anatut. 2013. Model Pesantren Rakyat Al-Amin di Sumberpucung Kabupaten Malang. Program Studi Pendidkan Agama Islam, sekolah Pascasarjana Universitas Islam Negeri (UIN) Maulana Malik Ibrahim Malang. Pembimbing I: Dr. H. Munirul Abidin, M.Ag. Pembimbing II: Dr. H. Zulfi Mubarag, M.Ag.
\end{abstract}

\title{
Kata Kunci: Model Pesantren
}

Sistem merupakan suatu keseluruhan dari unsur-unsur pendidikan yang berkaitan dan berhubungan satu sama lain serta saling mempengaruhi dalam mencapai suatu tujuan. Salah satu upaya yang dapat dilakukan adalah melalui pegembangan sistem pendidikan pesantren yang ada, sedangkan model merupakan hasil dari pengembangan sistem.

Fokus penelitian ini adalah bagaimana model Pesantren Rakyat Al-Amin di Sumberpucung Kabupaten Malang yang meliputi beberapa komponen pesantren yaitu: pondok, masjid, pengajaran kitab-kitab Islam klasik, santri dan kiai.

Penelitian ini menggunakan pendekatan studi kasus di Pesantren Rakyat Sumberpucung Kabupaten Malang. Bahan deskripsi didapatkan melalui Observasi, wawancara, dan dokumentasi. Subyek penelitian adalah kiai Pesantren Rakyat, lurah, ustadz, dan santri Pesantren Rakyat. Sampel penelitian yang digunakan adalah purposive sampling. Teknik yang digunakan untuk memperoleh kredibilitas data adalah triangulasi. Data yang diperoleh dari informan dan subyek yang diteliti disaring dan diklasifikasikan menurut pola, tema dan topik pembahasan. Analisis data dilakukan dengan dua tahap, yaitu tahap bersamaan dengan proses pengumpulan data di lapangan dan tahap sesudah pengumpulan data.

Hasil penelitian ini menunjukkan bahwa komponen pesantren pada umumnya dengan komponen yang ada di Pesantren Rakyat terdapat sebuah perbedaan. Secara nyata Pesantren Rakyat hanya memiliki 3 komponen pesantren yaitu pengajaran kitab Islam klasik, santri dan kiai, namun bukan berarti menganggap sebagian komponen yang tidak ada itu tidak penting, hanya saja beberapa komponen yang ada memiliki fungsi yang berbeda, jika pada penelitian Dhofier disebutkan bahwa komponen pesantren yang pertama "pondok" mempunyai fungsi sebagai tempat tinggal santri dari jauh, maka di Pesantren Rakyat ini cukup menggunakan rumah rakyat sebagai tempat tinggal santri, dengan tujuan agar santri mampu membaur dengan rakyat. Kedua Masjid, masjid merupakan komponen yang sangat penting bagi pesantren. Namun, Pesantren Rakyat lebih menekankan pada pemanfaatan masjid/mushola di sekitar pesantren, tanpa harus mempunyai bangunan masjid sendiri di dalam pesantren, layaknya pesantren pada umumnya. Ketiga Pengajaran kitab Islam klasik, Pesantren Rakyat tetap mengajarkan kitab-kitab Islam klasik namun bukan menjadi sentral pelajaran untuk santri, santri di sini lebih dibebaskan dalam pembelajarannya yakni sesuai bakat, minat dan kemampuan yang mereka miliki, serta belajar dan pembelajrannya tidak terpaku di Pesantren Rakyat saja, namun mampu memanfaatkan rakyat yang mempunyai kemampuan di bidang yang santri 
butuhkan. Keempat santri, santri Pesantren Rakyat terbagi menjadi 3 yaitu santri inti, santri kalong dan santri pendukung. Makna santri "kami yang belajar, kami yang mengajar dan kami yang memberi gelar". Kelima kiai, kiai Pesantren Rakyat selain sebagai pendiri dan sosok sentral juga bisa menjadi seorang sahabat, teman dan figur inspiratif untuk santrinya. Dari sini bisa terlihat bahwa Pesantren Rakyat merupakan pesantrennya rakyat, kehidupan ala rakyat, kurikulum ala rakyat, dan pembelajarannya ala rakyat yang ditumpangi dengan nilai-nilai keIslaman serta keindonesiaan agar generasi penerus bangsa mampu merakyat bukan mencekik rakyat serta mampu menjadikan bangsa Indonesia menjadi baldatun thoyyibatun warobbun ghofur. 


\begin{abstract}
Thoifah, I'anatut. 2013. Model of "Rakyat Al Amin" Islamic Boarding School in Sumberpucung, Kab. Malang. Islamic Education Study Program, Post Graduate School of State University Maulana Malik Ibrahim Malang. Supervisor I: Dr. H. MunirulAbidin, M. Ag. Supervisor II: Dr. H. ZulfiMubarag, M. Ag.
\end{abstract}

Key word: Model of Islamic Boarding School

System is a set of elements of education which are related and connected each other and give influence each other to achieve a certain goal. One of attempt that can be done is through developing system of Islamic Education there, while the model is a product of developing system.

Focus of this research is how the model of "Rakyat Al Amin" Islamic boarding school in SumberpucungKab. Malang including some components of Islamic boarding school itself: boarding, mosque, Islamic classic books, students and kiyai.

This research used study case approach in "Rakyat" Islamic boarding school in SumberpucungKab. Malang. The description matter is got by observation, interview, and documentation. The subject of research is Kyai of "Rakyat" Islamic boarding school, headman, teacher and students or Rakyat Islamic boarding school. The sample of research that used is purposive sampling. Technique that used to get credibility of data is triangulation. Data is got from informan and the subject who is researched, filtered and classified according to the pattern, theme and topic of discussion. Analyzing data done through two steps, the first step is step with the process of collecting data in the field and step after collecting data.

The result of this research shows the difference of the components of Islamic boarding school commonly and the components of Rakyat Islamic boarding school. In the reality Rakyat Islamic boarding school only has 3 components such as teaching Islamic classic book, students and kyai, but it doesn't mean that the other components of Islamic boarding school are not important, the other components just have different function, if in the Dhofierresearch mentioned that components of Islamic boarding school, the first is boarding which has function as place for students to stay in, so that this Rakyat Islamic boarding school only uses villager's house as a place, it aims in order to make students are closer with society. The second is mosque, mosque is an important place in Islamic boarding school. But, in Rakyat Islamic boarding school is more emphasize in utilizing mosque around Islamic boarding school, without build mosque like Islamic boarding school commonly which has their own mosque. The third is teaching Islamic classic book, Rakyat Islamic boarding school still teach Islamic classic book but not as central lesson for students, students in over there are freedom in learning that is based on their talent, willing and their own ability, and the learning is not stagnant in Rakyat Islamic, but it can utilize society who has ability in the field needed by students. The forth is students, students of Rakyat Islamic boarding school are divided into three: main 
students, kalong students and supporter students. The meaning of students is "we are learning, we are teaching and we are giving degree. The fifth is kyai, kyai of Rakyat Islamic boarding school except as the founder and central figure also can be friend and inspiring figure for his students. From here it can be seen that Rakyat Islamic boarding school is boarding for its society, society life style, society's curriculum and society's learning which is contained Islamic values and getting Indonesian so that the next generation is able to socialize and not killing Indonesian people and also can make the nation become baldatunthoyyibatunwarobbunghofur. 


\section{مستخلص البحث}

الطائفة، إعانة.2013.الأسلوب في المعهد للمجتمع"الأمين" في سومبير فوجوع بمالانج. قسم تربية الإسلامية .جامعة مولانا مالك إبراهيم الإسلامية الحكومية بمالانج. تحت

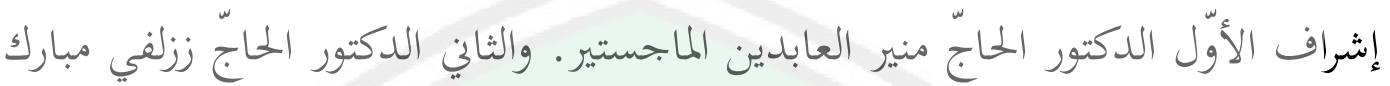
الماجستير. الكلمة الرئيسية: الأسلوب في المعهد

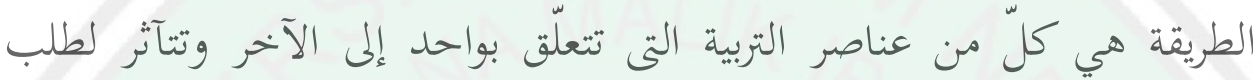
المراد. ومن بعض المحاولة منه هيالأسلوبالطريقة للمعهد.

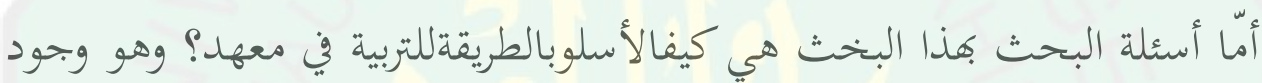
المعهد، المسجد، تدريس الكتب الإسلاميّ السلفيّ، الطلبة وكياهي. وقد استعمل هذا البحث طريقة المنهج القضية في المعهد للمجتمع سومبير فوجوع بمالانج. و البيانات أخذت بالمقابلة والملاحظة وبمصادر الكتب. والموضوع عن هذا البحث تعنى كياهي في معهد المحتمع، رئيس القرية، الأساتذ والطلبة بذالك المعهد. البيانات لهذا البحث Purposive Sampling وهو الكيفية لتصحيح البيانات المنهج ثلاث مصحّح. أمّا البيانات التي تُطلَب عن المُخبر والمبحوث منه حُّلَّت ويقسّم بأسلوبها.

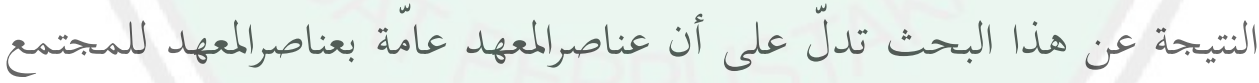
هناك الفرق عندهم فبظاهرة المعهد للمجتمع عنده ثناثة عناصرالمعها وهن تدريس

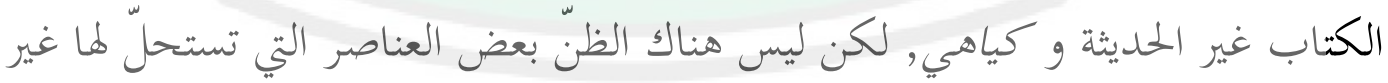

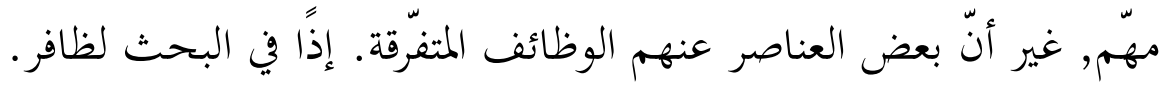

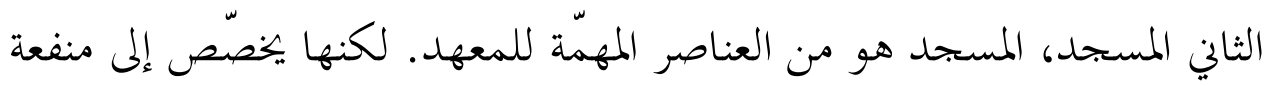
المسجد أو المصلّى حول المعهد ولو ليس هناك المسجد داخل المعهد عادة. الثالث هو تدريس الكتاب السلفي، وبهذا المعهلد فيه دروس الكتب السلفي لكن ليس فيها الترتيب المُلزمَ للطّلبة بل الإدارة لإستطاعة نفسهم والدراسة التى ليس فيها المخصوص للطلبة لكن 
هناك للمجتمع أيضا. الرابع أنّ الطلبة في المعهد يقسّم إلى ثلاثة الطلبة والخامس مكانة كياهي كالصاحب وليس من المؤسّس والمدرّّ فحسب بل كالصادق والإنسان المثالّي لحمّاسة الطلبة. والمعلمّم هنا ينظر أنّ المعهد للمجتممع هو مكان الدراسة للمجتمع، كلّ مولّ أنشطة فيه كمثل في المتمع عامّة الترتيب والمعهد كمثله والزيادة في الدراسة قيمة الإسلامية وبلاد الإندونسية لكى تكونوا الشَبّاب في البلاد الممتاز وأصبحوا بلدة طيّة 


\section{BAB I}

\section{PENDAHULUAN}

\section{A. Konteks Penelitian}

Selama ini kita tahu pendidikan baik formal atau pesantren di rasa menakutkan karena beberapa syarat dan biaya yang cukup rumit dan tinggi untuk kalangan orang awam, katakanlah Gontor (tidak mungkin anaknya orang tidak punya bisa mengenyam pendidikan semahal itu) sehingga potensi-potensi jiwa agamawan dan negarawan yang ada pada anak rakyat kecil tidak tersentuh dan tidak akan pernah ada perkembangan. Padahal banyak mutiara-mutiara, emas permata besar yang terpendam di keluargakeluarga lemah yang selama ini mengalami jalan buntu dalam menembus ruang kehidupan yang lebih bermartabat.

Fenomena perkembangan abad mutakhir menghendaki adanya model pendidikan yang komprehensif. Karena perkembangan masyarakat dewasa ini menghendaki adanya pembinaan anak didik yang dilaksanakan secara seimbang antara nilai dan sikap, pegetahuan, kecerdasan dan keterampilan, serta kemampuan komunikasi dan kesadaran akan ekologi lingkungannya. Azas pendidikan yang demikian itu juga merupakan suatu syarat untuk proses 'pembudayaan' yang akan mempersiapkan seorang warga guna melakukan suatu pekerjaan yang menjadi mata pencahariannya dan berguna bagi masyarakatnya, serta mampu menyesuaikan diri secara konstruktif terhadap perubahan-perubahan yang terjadi disekitarnya. 
Pendidikan berbasis masyarakat sebagai wahana dan sarana strategis sebagai perwujudan demokratisasi pendidikan senantiasa menghendaki adanya keterlibatan, dukungan, dan kepemilikan masyarakat dalam bidang pendidikan, yang terbebas dari intervensi pemerintah. Slogan "bebaskan pendidikan dari belenggu kekuasaan"1 dan "kembalikan pendidikan kepada masyarakat"2 merupakan inti wacana pendidikan berbasis masyarakat. Dengan slogan ini, dapat dilihat secara sepintas bahwa pendidikan berbasis masyarakat merupakan konsepsi yang perlu mendapat perhatian serius dari masyarakat Indonesia.

Oleh karena itu, ketika pemerintah melalui UU Sisdiknas 2003 mengungkapkan konsepsinya mengenai pendidikan berbasis masyarakat, sebenarnya pemerintah bersikeras mengutamakan kepentingan politiknya untuk mempertahankan kekuasaannya melalui kontrol pendidikan, bukan untuk kepentingan masyarakat. Dari sinilah kajian mengenai pendidikan berbasis masyarakat ditinjau dari pendidikan kritis menjadi sesuatu yang penting dan mendesak untuk dilakukan. Ditambah lagi, partisipasi masyarakat dalam pendidikan di Indonesia, menurut Suyata, bukanlah hal yang baru. Ia telah dilaksanakan oleh yayasan-yayasan swasta, kelompok sukarelawan, organisasi-organisasi non-pemerintah, dan bahkan oleh perorangan. ${ }^{3}$ Secara khusus Azyumardi Azra menyebutkan, dikalangan masyarakat muslim Indonesia, partisipasi masyarakat dalam rangka pendidikan berbasis

\footnotetext{
${ }^{1}$ Hadi Supeno. Pendidikan Dalam Belenggu Kekuasaan, Cet. I (Magelang: Pustaka Paramedia, 1999)

${ }^{2}$ Winarno Surakhmad. Kembalikan pendidikan Pada Masyarakat. Dalam http://www.kompas.com/kompas\%2Dcetak/0111/20/dikbud/kemb09.htm. berita ini dimuat dalam harian kompas 20 November 2001. (diakses 10 April 2013)

${ }^{3}$ Suyata. Community Participation in school Development: Acces, Demand, and School Contruction (Jakarta: Directorate of Seconday Education, Directorate General of Primay and Secondary Education, Ministry of Education and Culture, 1996). Hlm. 2
} 
masyarakat telah dilaksanakan lebih lama lagi, yaitu setua sejarah perkembangan Islam di bumi nusantara. Hampir seluruh lembaga pendidikan Islam di Indonesia, dari rangkang, dayah, meunasah (Aceh), surau (Minangkabau), pesantren (Jawa), bustanul atfal, diniyah, dan sekolahsekolah Islam lainnya didirikan dan dikembangkan oleh masyarakat muslim sendiri. ${ }^{4}$

Hal ini mengidentifikasikan bahwa pendidikan berbasis masyarakat di Indonesia sebenarnya telah dapat diterapkan sejak awal secara praktis. Namun, pada dataran teoritis, pendidikan berbasis masyarakat belum memiliki konsep dan teori yang jelas. Lain halnya dengan Pesantren Rakyat, pesantren ini tumbuh dan berkembang di tengah-tengah lingkungan masyarakat stasiun, pasar, perjudian, togel, perselingkuhan, tempat wisata, penginapan gelap dan daerah prostitusi terbesar di Kabupaten Malang, dimana masyarakatnya sangat plural atau heterogen. Sehingga mempengaruhi mental dan prilaku keseharian masyarakat dan generasi muda di sekelilingnya. Dengan kekuatan modal dan kemampuan yang serba minimalis, Pesantren Rakyat ingin ambil bagian dalam proses perubahan sosial ke arah yang lebih baik demi terciptanya masyarakat yang saling memanusiakan manusia dan bertaqwa kepada Allah Swt, demi terwujudnya cita-cita bangsa Indonesia menjadi Negara gemah ripah loh jinawe toto tentrem kerto raharjo.

\footnotetext{
${ }^{4}$ Azyumardi Azra, "Masalah dan Kebijakan Pendidikan Islam di Era Otonomi Daerah" makalah disampaikan pada Konferensi Nasional Manajemen Pendidikan di Hotel Indonesia, Jakarta 8-10 Agustus 2002, kerja sama Universitas Negeri Jakarta dengan Himpunan Sarjana Administrasi Pendidikan Indonesia, hlm. 5-6
} 
Untuk itu Pesantren Rakyat mempunyai keinginan menyantrikan rakyat, maka membuat semua kurikulum ala rakyat, ngaji kebutuhan rakyat, perekonomian ala rakyat, pertemuan atau diskusi ala rakyat, pendidikan ala rakyat, menejemen ala rakyat, pakaian ala rakyat, pergaulan ala rakyat dan dalam berbagai aspek bidang kehidupan konsepnya selalu ala rakyat, namun diberi masukan nilai-nilai Islam yang sesuai dengan ajaran Allah Swt dan Nabi Muhammad Saw serta para ulama' terdahulu, baik dalam tataran syari'at, tharekat, hakikat atau ma'rifatnya. ${ }^{5}$

Berbagai problematika dan hal yang diuraikan di atas menjadikan peneliti tertarik untuk mengangkat sebuah penelitian yang berjudul pengembangan sistem pendidikan Pesantren Rakyat di Sumberpucung Kabupaten Malang.

\section{B. Fokus Penelitian}

Fokus penelitian ini adalah bagaimana model komponen Pesantren Rakyat Al-Amin di Sumberpucung Kabupaten Malang yang meliputi beberapa komponen pesantren yaitu pondok, masjid, pengajaran kitab-kitab Islam klasik, santri, dan kiai?

\section{Tujuan Penelitian}

Tujuan umum penelitian ini adalah untuk mengetahui, mendiskripsikan dan menganalisis model komponen Pesantren Rakyat AlAmin di Sumberpucung Kabupaten Malang yang meliputi beberapa

\footnotetext{
${ }^{5}$ Sambutan Ust Abdullah Sam, S.Psi (Pengasuh Pesantren Rakyat). Malang, Rabu 25 Juni 2008
} 
komponen pesantren yaitu pondok, masjid, pengajaran kitab-kitab Islam klasik, santri, dan kiai.

\section{Manfaat Penelitian}

a. Teoritis

Dapat memberikan kontribusi teoritis dalam mengembangkan model pesantren sebagai salah satu cara untuk mewujudkan tujuan pendidikan yang merakyat dan bukan mencekik rakyat, masyarakat yang saling memanusiakan manusia dan bertaqwa kepada Allah SWT, selain itu juga demi terwujudnya cita-cita bangsa Indonesia menjadi Negara gemah ripah loh jinawe toto tentrem kerto raharjo, dan penelitian ini juga dapat dijadikan acuan bagi peneliti selanjutnya untuk bisa dikembangkan lagi.

b. Praktis

1. Bagi lembaga pendidikan (sekolah maupun perguruan tinggi)

Dari hasil penelitian ini bisa memberikan masukan, deskripsi dan analisis tentang model pesantren yang merakyat. Serta menjadi acuan dalam pengembangan pendidikan di Indonesia sehingga pendidikan di Indonesia mampu menampung dan memberi fasilitas siswa/santri dari berbagai golongan dengan tujuan untuk memanusiakan manusia serta mengurangi adanya anak putus sekolah karena mahalnya biaya pendidikan yang tak mampu diakses oleh orang-orang miskin.

2. Manfaat bagi Pesantren Rakyat Sumberpucung Kabupaten Malang

Hasil penelitian ini akan memberikan deskripsi serta analisis dari segi model pesantren yang ada, sehingga beberapa penemuan akan 
menjadi bahan diskusi bagaimana model Pesantren Rakyat jika dipandang dari segi yang lain.

\section{E. Originalitas Penelitian}

Penelitian mengenai model Pesantren Rakyat belum pernah dilakukan sebelumnya. Dari hasil studi yang peneliti lakukan, fokus penelitian yang peneliti ajukan juga belum pernah diteliti. Namun penelitian tentang pesantren sudah sering dilakukan, secara global akan penulis kemukakan karya tulis penelitian yang membahas tentang pesantren:

Mestuhu dengan "Dinamika Sistem Pendidikan Pesantren" (1994), meneliti enam pondok pesantren yang dijadikan objek studinya, yaitu: PP AnNuqayah, Guluk-Guluk Sumenep, PP Salafiyah Ibrahimiyah Situbondo, PP Blok Agung Jajak Banyuwangi, PP Tebuireng Jombang, PP Karangasem Muhammadiyah Paciran Lamongan, dan PP Modern Darussalam Gontor Ponorogo. Dia berusaha memaparkan unsur-unsur yang terdapat dalam sistem pendidikan pesantren dan mengungkap tentang nilai-nilai luhur yang dikandung dalam unsur-unsur tersebut; maka diantaranya yang perlu dikembangkan lebih lanjut, dipertahankan, dirubah, dan disempurnakan atau diperbaiki lebih dulu sebelum dikembangkan dalam sistem pendidikan nasional.

Di samping itu, Mastuhu mengungkap tentang dinamika sistem pendidikan pesantren dalam menghadapi tantangan zamannya, yaitu kebutuhan pembangunan nasional lengkap dengan kemajuan ilmu dan teknologi yang dibutuhkan. 
M. Ridlwan Nasir, menulis "Dinamika Sistem Pendidikan di Lingkungan Pondok Pesantren Tebuireng" (tesis tahun 1988), berusaha mengungkap sistem pendidikan yang ada di pondok pesantren Tebuireng yang meliputi: sistem pondok pesantren (sorogan dan weton), sistem madrasah (Madrasah Salafiyah Syafi'iyah tingkat Tsanawiyah dan Aliyah) dan sistem sekolah umum (SMP dan SMA A. Wahid Hasyim). Perpaduan antara sistem madrasah merupakan sistem yang sangat bermanfaat dan masih relevan dengan kondisi masyarakat Indonesia dewasa ini. Pondok pesantren Tebuireng selain mendidik para siswa/santri untuk menjadi orang yang kuat Islamnya, juga mendidik agar mereka memiliki pengetahuan keduniawian sebagai bekal untuk memperoleh profesi dalam sistem kehidupan modern, sehingga mereka benar-benar tidak gagap yakni siap pakai.

Clifford Geertz, secara tidak langsung memberi berbagai keterangan mengenai pesantren, pada tahun 1963 membahas secara khusus tentang perkembangan agama Islam dalam hubungannya dengan peranan madrasah dan pesantren dilihat dari sudut modernisasi masyarakat Islam dengan Jawa sebagai sampelnya. Dan dalam tesisnya mengenai pola kultural santri, abangan dan priyayi, yang tak luput pula membahas tentang nilai-nilai yang dilahirkan oleh dunia pesantren itu sendiri.

Zamakhsyari Dhofier dengan "Tradisi Pesantren" nya telah berusaha mengungkap dunia pesantren dengan wawasan agak luas. Beliau mengemukakan tentang ciri-ciri umum pesantren, dengan memfokuskan pada sistem pengajaran yakni sistem sorogan, bandongan (weton), musyawarah 
dan wirid thariqat di Jawa. Lebih khusus lagi beliau banyak menguraikan kehidupan para santri dan kiainya.

Hiroko Horikoshi dengan "Kiai dan Perubahan Sosial"nya telah berusaha mengungkap tentang peran kyai dalam perubahan sosial sebagai tokoh sentralny adalah Kiai Yusuf Tajir. Penelitian yang dilakukan oleh Hiroko Horikoshi memaparkan beberapa kesimpulan yang penting untuk menangkap jalannya proses perubahan yang dibawakan oleh pandangan hidup tradisional ke arah modernitas hidup dengan watak emansipatoris. Horikoshi juga mengemukakan tentang kiai sebagai tokoh kharismatik, sehingga mudah dalam memelopori perubahan sosial dengan caranya sendiri.

Hasil survey kolektif mahasiswa Program Sarjana Muda Fakultas Tarbiyah IAIN Sunan Ampel Bojonegoro tahun 1983-1984, memberi gambaran secara global tentang sistem pendidikan pondok pesantren, baik yang tradisional seperti sorogan dan weton maupun klasikal seperti lembaga pendidikan agama (MI, MTs, dan MA) dan lembaga pendidikan umum (SMP dan SMA). Fokus pembahasannya pada sejarah pondok pesantren dan penyelenggaraannya serta penyelenggaraan sistem klasikal.

Imron Arifin, dengan "Kepemimpinan Kiai” (tahun 1992), mengunkap tentang kepemimpinan kiai dan pengajaran kitab Islam klasik di pesantren Tebuireng. Ditemukan tentang terjadinya pergeseran gaya kepemimpinan kiai, yang pada mulanya seorang kiai di pesantren sangat sentral, pada perkembangan selanjutnya keadaan itu bergeser yakni kiai sudah mulai dibantu beberapa orang. 


\section{F. Definisi istilah}

1. Pendidikan berbasis rakyat adalah pendidikan yang dirancang, dilaksanakan, dinilai, dan dikembangkan oleh rakyat yang mengarah pada usaha menjawab tantangan dan peluang yang ada di lingkungannya dengan berorientasi pada masa depan. Dengan kata lain, pendidikan berbasis rakat adalah konsep pendidikan "dari rakyat, oleh rakyat, dan untuk rakyat". pendidikan berbasis rakyat merupakan proses pendidikan yang lahir dari kebutuhan rakyat. Oleh karena itu ia tak perlu dikekang oleh aturan-aturan formal dari pemerintah.

2. Pesantren Rakyat merupakan lembaga pendidikan pesantren berbasis rakyat yang aktifitas dan kurikulumnya ala Rakyat, "kita yang belajar, kita yang mengajar dan kita yang memberi gelar" santri Pesantren Rakyat terdiri dari semua kalangan, semua orang yang mengaku rakyat, dan tidak pandang bulu, baik dari kalangan alit maupun elit, dari kalangan korak maupun qori'.

3. Rakyat adalah segenap penduduk suatu Negara (sebagai imbangan pemerintah); orang kebanyakan; orang biasa. ${ }^{6}$

${ }^{6}$ Ibid., hlm. 1159 


\section{BAB II}

\section{KAJIAN TEORI}

\section{A. Sistem}

\section{Pengertian sistem}

Istilah sistem berasal dari bahasa yunani System yang berarti hubungan fungsional yang teratur antara unit-unit atau komponenkomponen. ${ }^{1}$ Untuk mempertegas dan memperjelas pengertian di sini, penulis ingin mengemukakan beberapa definisi tentang sistem yang dekat dengan dunia pendidikan, khususnya dengan sistem pendidikan di lingkungan pondok pesantren.

Tatang M. Arifin mengemukakan tentang pengertian sistem sebagai berikut:

1. Suatu keseluruhan yang tersusun dari sekian bagian.

2. Hubungan yang berlangsung di antara satuan-satuan atau komponen secara teratur. Sistem adalah jumlah keseluruhan dari bagian-bagian yang bekerja secara sendiri-sendiri dan bersama untuk mencapai hasil yang diperlukan, berdasarkan keperluan. Jadi, dengan kata lain istilah "system" itu mengandung arti komponen yang saling berhubungan secara teratur dan merupakan satu keseluruhan yang bekerja secara sendiri-sendiri maupun bersama untuk mencapai satu tujuan.

\footnotetext{
${ }^{1}$ Tohari Musnamar, Bimbingan dan Wawanwuruk sebagai Suatu Sistem (Yogyakarta: Cendikia Sarana Informatika, 1985), hlm. 38
} 
Rumusan lain menyatakan, bahwa sistem adalah kumpulan berbagai komponen yang berinteraksi satu dengan lainnya membentuk suatu kesatuan dengan tujuan yang jelas. ${ }^{2}$ Dengan demikian, sistem merupakan himpunan komponen-komponen atau bagian yang saling berkaitan yang bersama-sama berfungsi untuk mencapai suatu tujuan.

Dari paparan di atas, maka yang dimaksud dengan sistem pendidikan dapat diartikan sebagai suatu keseluruhan dari unsur-unsur pendidikan yang berkaitan dan berhubungan satu sama lain serta saling mempengaruhi, dalam satu kesatuan. Hal ini tepat jika dikaitkan dengan sistem pendidikan pondok pesantren, dimana para pengasuh pesantren memandang bahwa belajar- mengajar merupakan kesatu paduan atau lebur dalam totalitas kegiatan hidup sehari-hari. Bagi warga pesantren, belajar di pesantren tidak mengenal perhitungan waktu, kapan harus mulai dan harus selesai, dan target apa yang harus dicapai.

\section{Ciri-ciri Sistem ${ }^{3}$}

Untuk mengetahui suatu sistem atau bukan, antara lain dapat dilihat dari ciri-cirinya. Ada beberapa rumusan mengenai ciri-ciri sistem ini yang pada dasarnya satu sama lain melengkapi. Pada umumnya ciri-ciri sistem itu adalah: bertujuan, punya batas, terbuka, tersusun dari sub sistem, ada saling keterkaitan dan saling tergantung, merupakan satu kebulatan yang

\footnotetext{
${ }^{2}$ Fuad Amsyari, keharmonisan Lingkungan sebagai Determinan Keberhasilan Pembangunan Pendidikan: Suatu Analisis dari Pandangan Islam (Surabaya: Indah Offset, IAIN Sunan Ampel, 1986), hlm. 52

${ }^{3}$ Ridlwan Nasir. Mencari Tipologi Format Pendidikan Ideal (Yogyakarta: Pustaka Pelajar, 2005), hlm. 28
} 
utuh, melakukan kegiatan transformasi, ada mekanisme kontrol, dan memiliki kemampuan mengatur dan menyesuaikan diri sendiri.

\section{Tujuan Sistem}

Satu sistem bisa mempunyai tujuan lebih dari satu macam tujuan. Secara umum tujuan sistem adalah menciptakan sesuatu yang berharga dan mempunyai nilai, entah apa wujud dan ukurannya. Penciptaan atau pencapaian sesuatu yang bernilai itu dilakukan dengan memadukan dan mendayagunakan berbagai macam bahan atau dengan suatu cara tertentu. Misalnya, sekolah yang terdiri dari: orang, kurikulum, sarana dan prasarana. Tujuan khusus sistem tersebut antara lain: a. Manusia dapat terdidik; b. pengembangan ilmu; c. Pembinaan masyarakat. ${ }^{4}$

Sebagaimana telah dikemukakan bahwa tujuan suatu sistem bisa lebih dari satu. Dengan kata lain sistem itu mempunyai tujuan ganda. Dari sekian tujuan tersebut mungkin salah satunya merupakan tujuan yang terpenting, tujuan yang paling mendasar, atau yang mendapatkan prioritas untuk dicapai (diusahakan pencapaiannya) terlebih dahulu. Dasar apakah yang dipergunakan untuk menentukan suatu tujuan itu diprioritaskan, tentu bermacam-macam. Kaitannya dengan ini, Shrode dan Voich mengemukakan, ada 4 (empat) tolak ukur atau kriteria untuk memilih penting atau tidaknya suatu tujuan yaitu: ${ }^{5}$

\footnotetext{
${ }^{4}$ Ibid., hlm. 28-29

${ }^{5}$ Tatang M. Amirin, Pokok-pokok Teori Sistem (Jakarta: Rajawali, 1986), hlm. 11, dalam Ridlwan Nasir, Mencari Tipologi Format Pendidikan Ideal (Yogyakarta: Pustaka Pelajar, 2005), hlm. 29
} 
Kriteria

Mutu (kualitasnya)

Banyaknya (kuantitasnya)

Waktu

Biaya
Sekolah/Madrasah

- Guru kompeten

- Disiplin tinggi

- Prestasi lulusan tinggi

- Daya tampung besar

- Banyak manghasilkan lulusan

- Waktu belajar singkat

- Biaya penyelenggaraan rendah, SPP rendah

Tabel 2.1

4 kriteria untuk memilih penting atau tidaknya suatu tujuan

Sudah barang tentu keempat kriteria atau patokan tersebut tidak selalu sejalan. Artinya, baik dari segi mutu, jumlah, waktu, maupun keuangan bisa dipilih yang paling menguntungkan. Adakalanya satu sama lain tidak sejalan. Ada orang yang memilih program diploma dengan perhitungan waktu belajarnya relatif singkat, pembiayaan juga tidak terlampau tinggi dan bisa segera bekerja, walaupun persoalan kompetensi (mutu) terpaksa terkorbankan.

Kriteria mana yang dipegang oleh seseorang atau suatu lembaga tergantung banyak hal: kebutuhan pribadinya, sistem nilai yang dianutnya, dan juga kemampuan keuangannya, dan dalam melakukan pemilihan tersebut muncul semacam perhitungan "untung rugi". Mana yang dipertimbangkan lebih menguntungkan, memilih berdasarkan kriteria mutu, jumlah, waktu, ataukah biaya, atau perpaduan diantaranya. 


\section{Keterbukaan}

Sistem keterbukaan dibedakan dua macam: ${ }^{6}$

1. Sistem terbuka adalah sistem yang berhubungan dengan lingkungannya, komponen-komponennya dibiarkan mengadakan hubungan keluar dari "batas luar" sistem.

2. Sistem tertutup adalah sistem yang terisolasikan dari segala pengaruh luar sistem itu sendiri, dari pengaruh sistem yang lebih besar atau lebih luas atau dari lingkunganya.

Dalam kenyataan sebenarnnya tidak ada sistem yang benar-benar tertutup, karena komponen-komponennya selalu dipengaruhi berbagai kekuatan yang ada di lingkungannya. Karena itulah dapat disimpulkan bahwa sistem itu pada dasarnya bersifat terbuka. Keterbukaan merupakan ciri sistem. Bagi sesuatu sistem, lingkungan itu merupakan sumber masukan (input) yang diolah oleh sistem tersebut menjadi keluaran (out put). Sebaliknya pula, lingkungan itu merupakan pemakai hasil keluaran sistem tersebut. Jadi, lingkungan merupakan sumber bahan yang akan dipergunakan oleh sistem, dan sekaligus merupakan pemakai hasil keluaran sistem tersebut.

Sehubungan dengan itu, maka suatu sistem pendidikan pondok pesantren disebut tertutup apabila dikaitkan dengan nilai mutlak, sebaliknya, disebut sistem terbuka apabila dikaitkan dengan nilai relative. Ide-ide baru yang datang dari luar tetap terbuka untuk diterima sebagai

${ }^{6}$ Ibid., hlm. 29, lihat juga Rusadi Kantaprawira, Aplikasi Pendekatan Sistem dalam Ilmu-ilmu Sosial (Jakarta: Bunda Karya, 1987), hlm. 21 
masukan yang dapat mempengaruhi sistem yang bersangkutan sepanjang hal itu tidak bertentangan dengan nilai mutlak yakni menggeser aqidahsyari'ah.

Di era pembangunan dan globalisasi seperti sekarang ini, pondok pesantren senantiasa bergumul antara mempertahankan identitas dengan keterbukaan terhadap sistem-sistem dari luar. Bukti inilah yang menunjukkan bahwa pondok pesantren telah mempertahankan pergeseran dan perubahan sesuai dengan zaman serta memiliki daya elastis tinggi.

\section{Kebulatan Keseluruhan}

Salah satu konsep kunci untuk melihat sistem adalah konsep kebulatan keseluruhan yang mengandung makna atau sifat "wholism". Maksud yang terkandung di dalam konsep ini adalah, bahwa sistem sebagai satu kesatuan yang bulat bukanlah sekedar kumpulan dari bagianbagiannya. Salah satu prinsip dari sistem pendidikan Islam adalah menggunakan metode pendekatan holistik ${ }^{7}$ (yang menyeluruh) terhadap manusia yang meliputi dimensi jasmani dan rohani, dan sesuai dengan fitrahnya yang meliputi semua aspek kemanusiaan dan kehidupan, baik yang dapat dijangkau oleh akal maupun yang hanya dapat diimani oleh hati. Semuanya dikembangkan secara menyeluruh dan seimbang, bukan hanya akalnya saja tetapi juga hatinya, bukan hanya lahiriah-nya saja tetapi juga batiniah-nya.

\footnotetext{
${ }^{7}$ Muhammad Qutub, Sistem Pendidikan Islam, Alih Bahasa Salman Harun, (Bandung: alMa'arif, 1984), hlm. 27
} 
Konsep saling berhubungan mencerminkan adanya interaksi internal dan saling ketergantungan di antara berbagai bagian atau komponen sistem dan antara sistem dengan lingkungannya. Saling berhubungan tersebut adalah, adanya hubungan guru dengan murid, hubungan guru dengan kepala sekolah, dan hubungan sekolah dengan masyarakat.

Di dalam organisasi, suatu sistem akan terlihat benar adanya hubungan itu, dan dapat dibedakan (biasanya) ke dalam hubungan yang bersifat menegak (vertikal) dan hubungan mendatar (horisontal). Contohnya adalah hubungan baik dan saling menghormati antara gurumurid, rasa hormat santri/murid kepada kiai/guru, berkeyakinan bahwa dirinya tidak akan menjadi orang yang baik dan pandai tanpa perantara kiai/guru, dan demikian juga santri/murid berkeyakinan bahwa ilmunya tidak akan bermanfaat bila tidak hormat kepada kiai/guru, serta kiai/guru melaksanakan tugas sebagai realisasi dari mengemban amanah dari Allah SWT. Kegiatan menyelenggarakan pendidikan dipandang sebagai ibadah kepada Allah SWT. Oleh sebab itu senantiasa dilandasi oleh rasa ikhlas dan ibtighaa mardlatillahi serta adanya solidaritas yang tinggi. ${ }^{8}$

${ }^{8}$ Ridlwan Nasir. Op,.Cit. hlm. 33 


\section{B. Pesantren}

\section{Pengertian pesantren}

Perkataan pesantren berasal dari kata santri, ${ }^{9}$ dengan awalan $P e$ di depan dan akhiran an berarti tempat tinggal para santri ${ }^{10}$ di Indonesia istilah pesantren lebih populer dengan sebutan pondok pesantren. Lain halnya dengan pesantren, pondok berasal dari bahasa Arab Fundîq yang berarti hotel, asrama, rumah, dan tempat tinggal sederhana. ${ }^{11}$

Pengertian terminologi pesantren di atas, mengindikasikan bahwa secara kultural pesantren lahir dari budaya Indonesia, secara historis pesantren tidak hanya mengandung makna keIslaman, tetapi juga makna keaslian Indonesia. Sebab, memang cikal bakal lembaga pesantren sebenarnya sudah ada pada masa Hindu-Budha, dan Islam tinggal meneruskan, melestarikan, dan mengIslamkannya. ${ }^{12}$

Pendapat serupa juga dapat terlihat dalam penelitian Karel A. Steenbrink:

\footnotetext{
${ }^{9}$ Dalam penelitiannya, Clifford Geertz berpendapat, kata santri mempunyai arti luas dan sempit. Dalam arti sempit santri adalah seorang murid satu sekolah agama yang disebut pondok atau pesantren. oleh sebab itulah perkataan pesantren diambil dari perkataan santri yang berarti tempat untuk para santri. Dalam arti luas dan umum santri adalah bagian penduduk jawa yang memeluk Islam dengan benar-benar, bersembahyang, pergi ke masjid dan berbagai aktifitas lainnya. Lihat Clifford Geertz, Abangan Santri, Priyayi dalam Masyarakat jawa, terj. Aswab Mahasin (Judul asli: The Religion Of Java), cet. ke-2, (Jakarta: Dunia Pustaka Jaya, 1983), hlm. 268; Abdul Munir Mulkhan, Runtuhnya Mitos Politik Santri, Strategi Kebudayaan dalam Islam, cet. ke-1, (Yogyakarta: Sipress, 1994), hlm. 1

${ }^{10}$ Zamakhsyari Dhofier, Tradisi Pesantren: Studi tentang Pandangan Hidup Kiai (Jakarta: LP3ES, 1994), hlm. 18; Tim Penyusun, Kamus Besar Bahasa Indonesia, cet. ke-2, (Jakarta: Balai Pustaka, 1989, hlm. 677; Saliman dan Sudarsono, Kamus Pendidikan, Pengajaran dan Umum, cet. ke-1, (Jakarta: Rineka Cipta, 1994), hlm. 180; Tim Penyusun, Ensklopedi Islam Indonesia (Jakarta: Djambatan, 1992), hlm. 771

${ }^{11}$ Hasbullah, Sejarah Pendidikan Islam di Indonesia, Lintasan Sejarah Pertumbuhan dan Perkembangan, cet. ke-2, (Jakarta: raja Grafindo Persada, 1996), hlm. 138

${ }^{12}$ Nurcholish Madjid, "Merumuskan Kembali Tujuan Pendidikan Islam” dalam Dawam Rahardjo, (ed), Pergulatan Dunia Pesantren, Membangun dari Bawah (Jakarta: P3M, 1985), hlm. 3
} 
Secara terminologis dapat dijelaskan bahwa pendidikan pesantren, dilihat dari segi bentuk dan sistemnya, berasal dari India. Sebelum proses penyebaran Islam di Indonesia, sistem tersebut telah dipergunakan secara umum untuk pendidikan dan pengajaran agama Hindu di Jawa. Setelah Islam masuk dan tersebar di Jawa, sistem tersebut kemudian diambil oleh Islam. ${ }^{13}$

Bila dilihat dari sistem pengajaran yang diterapkan di dunia pesantren, memang terdapat kemiripan dengan tatalaksana pengajaran dalam ritual keagamaan Hindu, dimana terdapatnya penghormatan yang besar oleh murid (santri) kepada kiainya. Sehubungan dengan hal ini Cak Nur menggambarkan, kiai duduk di atas kursi yang dilandasi bantal dan para santri duduk mengelilinginya. Dengan cara begini timbul sikap hormat dan sopan oleh para santri terhadap kiai seraya dengan tenang mendengarkan uraian-uraian yang disampaikan kiainya. ${ }^{14}$ Sehingga peran kiai sangat fenomenal dan signifikan dalam keberlangsungan atau eksistensi sebuah pesantren, sebab kiai adalah sebuah elemen dari beberapa elemen dasar sebuah pesantren.

Paparan di atas memberikan keterangan bahwa Pondok pesantren merupakan lembaga pendidikan Islam yang memberikan pendidikan dan pengajaran serta mengembangkan dan menyebarkan ilmu agama Islam, sedangkan orang yang belajar di pesantren disebut dengan santri, baik yang bertempat tinggal di dalam pesantren meski ada juga yang pulang pergi dari rumahnya masing-masing.

\footnotetext{
${ }^{13}$ Karel A. Steenbrink, Pesantren, Madrasah, Sekolah, Pendidikan Islam dalam Kurun Modern, terj. Karel A. Steenbrink dan Abdurrahman, cet. ke-2 (Jakarta: LP3ES, 1994), hlm. 20-21 dalam Yasmadi, Modernisasi Pesantren, Kritik nurcholish Madjid Terhadap Pendidikan Islam Tradisional (Jakarta: Ciputat Press, 2002), hlm. 62

${ }^{14}$ Nurcholish Madjid, Bilik-bilik pesantren Sebuah potret Perjalanan (Jakarta: Paramadina, 1997), hlm. 63
} 


\section{Karakteristik pesantren}

Secara fisik, sebuah pesantren biasanya terdiri dari unsur-unsur berikut: dipusatkan ada sebuah masjid atau langgar, surau yang dikelilingi bangunan tempat tinggal kiai (dengan serambi tamu, ruang depan, kamar tamu), asrama untuk pelajar (santri) serta ruangan-ruangan belajar. Pesantren sering berada di perbatasan pedesaan yang terpisah, dibatasi dengan pagar. Mereka kebanyakan menguasai lahan pertanian sendiri, yang sering dihibahkan oleh penduduk desa untuk tujuan-tujuan (wakaf). ${ }^{15}$

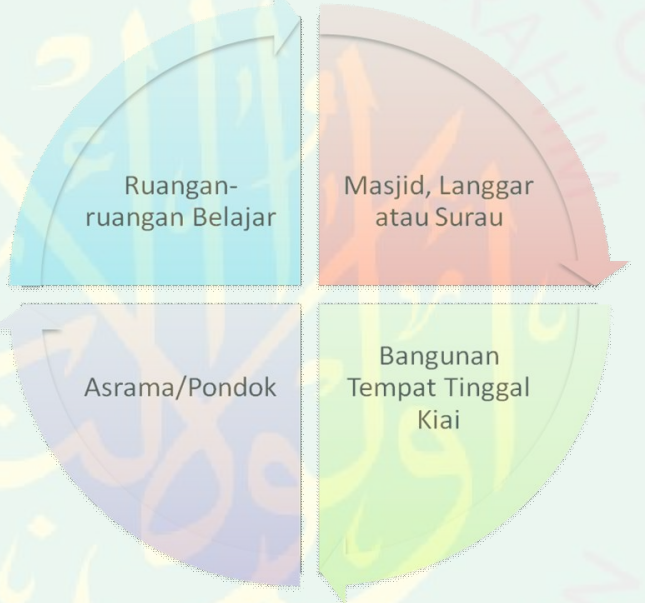

Skema 2.1 Empat komponen Pesantren menurut Manfred Ziemek

Dalam teori lain dijelaskan, bahwa pesantren memiliki karakteristik yang khusus. Adapun secara umum, dapat dikatakan bahwa karakteristik pesantren terletak pada komponen-komponen yang ada di dalamnya. Komponen-komponen yang dimaksud meliputi: pondok,

\footnotetext{
${ }^{15}$ Manfred Ziemek. Pesantren dalam Perubahan Sosial (Jakarta: P3M, 1986), hlm. 101
} 
masjid, santri, pengajaran kitab-kitab Islam klasik, dan kiai. Kelima komponen pesantren akan diuraikan secara singkat berikut ini. ${ }^{16}$

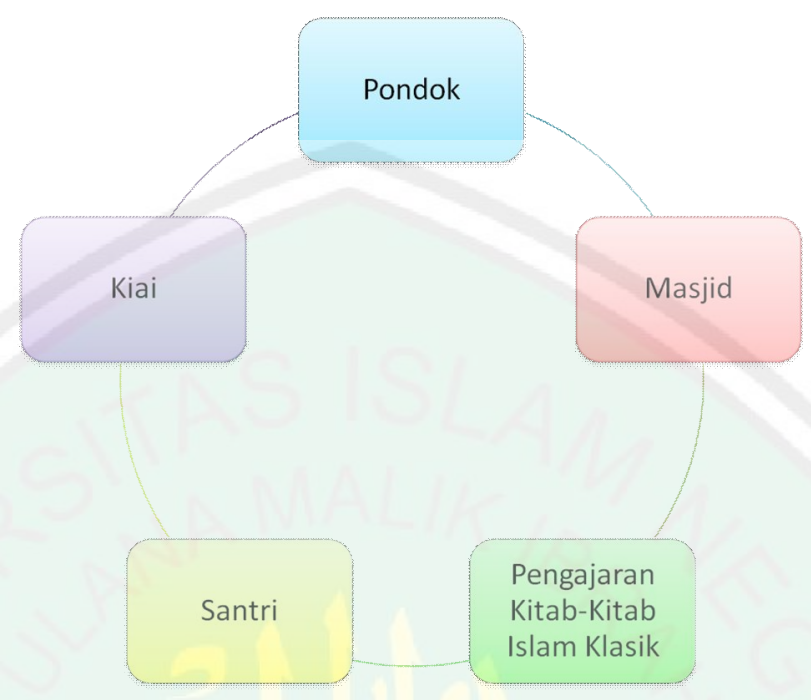

Skema 2.2 Lima Komponen Pesantren menurut Zamakhsyari Dhofier

a. Pondok

Kata pondok diambil dari bahasa Arab Fundûq yang berarti ruang tidur, wisma, dan atau hotel sederhana. Dalam pengertian ini, pondok merupakan asrama bagi santri yang menjadi ciri khas tradisi pesantren, yang membedakannya dengan sistem pendidikan Islam tradisional lainnya - seperti masjid, surau, dan atau langgar.

Menurut Zamakhsyari Dhofier, ada tiga alasan yang mendasari pesantren harus menyediakan asrama bagi para santrinya:

a. Kemasyhuran seorang kiai dan kedalaman pengetahuannya tentang Islam menarik para santri dari jauh, dan ini berarti memerlukan asrama;

\footnotetext{
${ }^{16}$ Zamakhsyari Dhofier. Tradisi Pesantren dalam Abdullah aly, Pendidikan Islam Multikultural di Pesantren (Yogyakarta: Pustaka Pelajar, 2011), hlm. 159
} 
b. Hampir semua pesantren berada di desa-desa dimana tidak tersedia perumahan (akomodasi) yang cukup untuk dapat menampung para santri, sehingga memerlukan asrama; dan

c. Adanya sikap timbal balik antara kiai dan santri, dimana para santri menganggap kiainya seolah-olah sebagai bapaknya sendiri, sedangkan kiai menganggap para santri sebagai titipan Tuhan yang harus senantiasa dilindungi. ${ }^{17}$

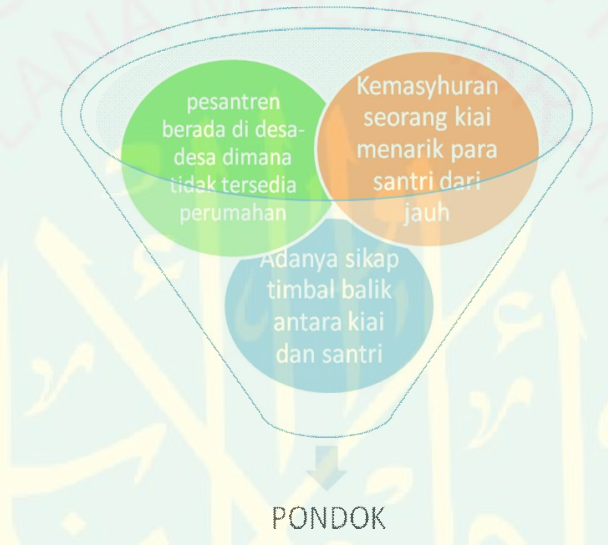

Skema 2.3 Alasan Adanya Asrama/Pondok

\section{b. Masjid}

Bagi pesantren, masjid tidak hanya berfungsi sebagai tempat ibadah sebagaimana pada umumnya masjid diluar pesantren, melainkan juga berfungsi sebagai tempat untuk mendidik para santri, terutama dalam praktik sholat lima waktu, khutbah dan sholat jum'ah, dan pengajaran kitab-kitab Islam klasik. Karena itu, masjid merupakan komponen yang tidak dapat dipisahkan dari pesantren. Secara historis, pesantren merupakan transformasi dari lembaga pendidikan Islam

${ }^{17}$ Zamakhsyari Dhofier, Op,. Cit, hlm. 47 
tradisional yang berpusat di masjid. Berkenaan dengan kedudukan masjid, Dhofier menulis:

"Kedudukan masjid sebagai pusat pendidikan Islam dalam tradisi pesantren merupakan manifestasi universalisme dari sistem pendidikan Islam tradisional. Dengan kata lain, kesinambungan sistem pendidikan Islam yang berpusat pada masjid sejak Masjid al-Quba' didirikan didekat madinah pada masa Nabi Muhammad saw tetap terpancar dalam sistem pesantren. Sejak zaman Nabi, masjid telah menjadi pusat pendidikan Islam. Dimanapun kaum muslimin berada, mereka selalu menggunakan masjid sebagai tempat pertemuan, pusat pendidikan, aktivitas administrasi dan cultural. Hal ini telah berlangsung selama 13 abad. Bahkan dalam zaman sekarang pun di daerah di mana umat Islam belum begitu terpengaruh oleh kehidupan barat, kita temukan para ulama yang dengan penuh pengabdian mengajar siswa-siswa di masjid, serta memberi wejangan dan anjuran kepada siswa-siswa tersebut untuk meneruskan tradisi yang terbentuk sejak zaman permulaan Islam itu" 18

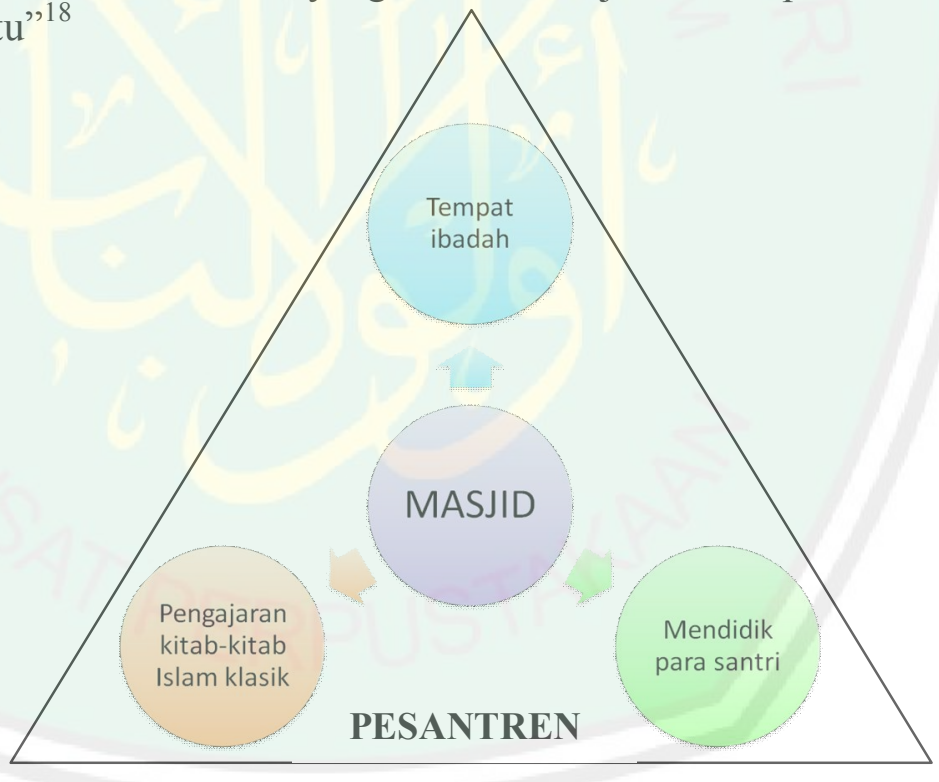

Skema 2.4 Fungsi Masjid

\section{c. Pengajaran kitab-kitab Islam klasik}

Pengajaran kitab-kitab Islam klasik di pesantren sesungguhnya merupakan upaya memelihara dan mentransfer literatur-literatur Islam

${ }^{18}$ Ibid,. Tradisi Pesantren. Op,.Cit, hlm. 49 
klasik yang lazim disebut kitab kuning dari generasi ke generasi selama beberapa abad. Menurut Abdurrahman Wahid, pengajaran kitab-kitab Islam klasik oleh pesantren dijadikan sebagai sarana untuk membekali para santri dengan pemahaman warisan keilmuan Islam masa lampau atau jalan kebenaran menuju kesadaran esoterik ihwal status penghambaan ( 'ubūdiyah) dihadapan Tuhan, bahkan juga dengan tugastugas masa depan dalam kehidupan masyarakat. ${ }^{19}$

Oleh sebab itu, pesantren bertugas untuk mencetak manusia yang benar-benar ahli dalam bidang agama dan ilmu pengetahuan kemasyarakatan serta berakhlak mulia. Untuk mencapai tujuan tersebut maka pesantren mengajarkan Tauhid, Fiqh, Tafsir, Hadits, Nahwu, Sharaf, Ma'ani, Badi' dan Bayan, Ushul al-Fiqh, Musthalah al-hadits, dan Mantiq. $^{20}$ Sedangkan metode yang lazim digunakan dalam pembelajaran kitab-kitab Islam klasik di pesantren adalah sorogan dan wetonan. Metode sorogan adalah metode pembelajaran kitab secara individual, dimana setiap santri menghadap secara bergiliran kepada kiai atau pembantunya, untuk membaca, menjelaskan, atau menghafal pelajaran yang diberikan sebelumnya. ${ }^{21}$ Dengan metode ini kiai mengetahui betul kemampuan para santrinya.

Sementara itu yang dimaksud dengan metode weton adalah metode pembelajaran kitab secara kelompok, dimana kiai membaca,

\footnotetext{
19 Abdurrahman Wahid, "Pondok Pesantren Masa Depan", dalam Sa'id Aqiel Siraj, et.al., Pesantren Masa Depan: Wacana Pemberdayaan dan Transformasi Pesantren (Bandung: Pustaka Hidayah, 1999), hlm. 16-17

${ }^{20}$ Ridlwan Nasir.,Op,.Cit. hlm. 310-311

${ }^{21}$ Nurcholish Madjid,. Bilik-bilik Pesantren. Op,.Cit. hlm. 28
} 
menerjemahkan, dan menjelaskan pengertian isi kitab yang dibawa. Pada saat proses pembelajaran, para santri bergerombol duduk mengelilingi kiai atau guru bantu, atau mereka mengambil tempat agak jauh selama suara sang kiai atau guru bantu dapat didengar. Metode ini lazim juga disebut bondongan dan atau halaqoh. Menurut Madjid, pengajian kitab dengan metode ini dilakukan atas inisiatif kiai sendiri, baik dalam menentukan tempat, waktu maupun kitabnya. ${ }^{22}$

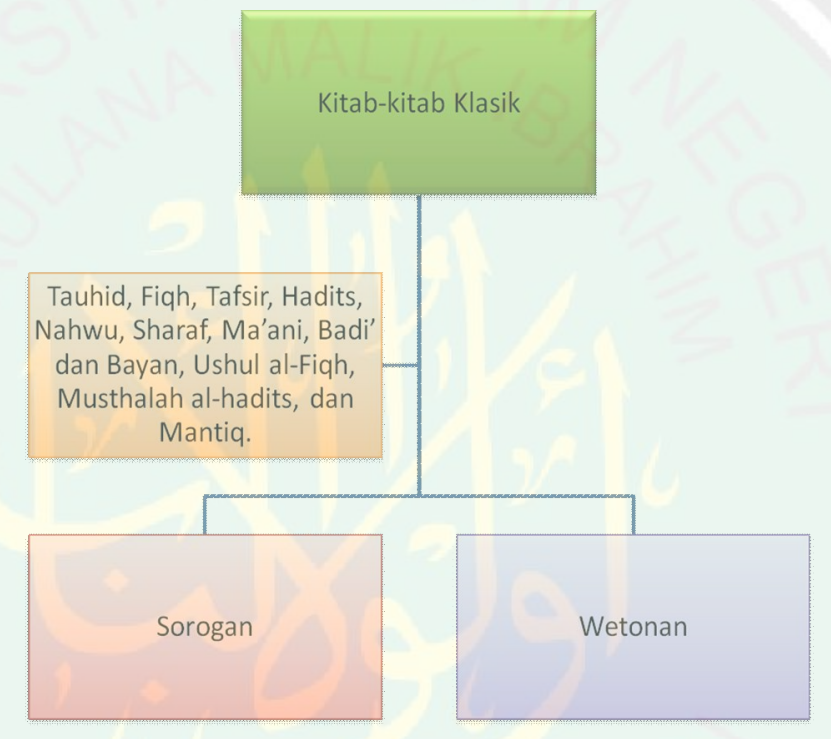

Skema 2.5 Pengajaran Kitab klasik

\section{d. Santri}

Kata "santri", menurut Madjid, jika dilihat dari asal usulnya memiliki dua pengertian:

a. Kata "santri" itu berasal dari perkataan "sastri", sebuah kata dari sansekerta, yang berarti melek huruf. ${ }^{23}$ Dalam arti ini, santri adalah

${ }^{22} \mathrm{Ibid}$,

${ }^{23}$ Ibid.,hlm. 19 
siswa di pesantren yang memiliki pengetahuan tentang Islam melalui kitab-kitab Islam klasik yang dipelajari.

b. Kata "santri" berasal dari bahasa jawa, persisnya dari kata "cantrik", yang artinya seseorang yang selalu mengikuti seorang guru kemana guru ini menetap, dengan tujuan dapat belajar darinya mengenai suatu keahlian. ${ }^{24}$ Dalam arti ini santri adalah siswa yang menetap di pesantren dimana kiai tinggal, dengan tujuan untuk memperdalam kitab-kitab Islam klasik yang diajarkan oleh kiai.

Tradisi pesantren mengenal dua kelompok santri, yaitu: ${ }^{25}$

a. Santri muqim yaitu santri yang menetap di asrama pesantren selama memperdalam kitab-kitab Islam klasik

b. Santri kalong santri yang selama memperdalam ilmu-ilmu keIslaman melalui kitab-kitab Islam klasik, mereka tidak menetap di asrama pesantren.

Jika melihat dari komitmennya terhadap nilai-nilai yang diajarkan oleh kiai, santri dapat dikelompokkan menjadi tiga macam. Menurut Suteja, ketiga kelompok santri tersebut adalah: ${ }^{26}$

1) Santri konservatif

Santri yang selalu membina dan memelihara nilai-nilai yang ada di pesantren dengan caranya masing-masing. Santri model ini harus belajar mengenal dan mengamalkan secara patuh

${ }^{24}$ Ibid., hlm. 20

25 Zamakhsyari Dhofier, Tradisi Pesantren: Studi tentang Pandangan Hidup Kyai (Jakarta: LP3ES, 1985), hlm. 53

${ }^{26}$ Suteja, "Pola Peikiran Kaum Santri: Mengacu Budaya Wali Jawa" dalam Sa'id Aqiel Siraj, et.al., Op.,cit. hlm. 77 
kaidah-kaidah keagamaan, kesusilaan, kebiasaan, dan aturanaturan hukum tanpa kritisisme yang rasional.

\section{2) Santri reformatif}

Santri yang berusaha mempertahankan dan memelihara kaidah-kaidah keagamaan, serta berusaha menggantikannya dengan bentuk dan model baru jika diperlukan. Argumen yang mereka ajukan adalah prinsip dan kata hikmah: "al-

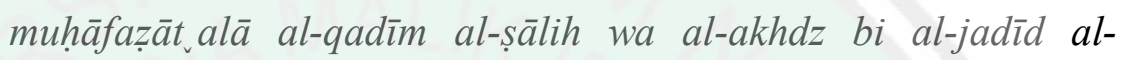
așlah", memelihara hal-hal lama yang baik dan mengambil halhal baru yang lebih baik.

3) Santri transformatif

Santri yang melakukan lompatan budaya dan intelektual secara progresif dengan tetap memperhatikan nilai-nilai dan kaidah-kaidah keagamaan yang mereka peroleh dari pesantren. Hal ini direfleksikan melalui pikiran-pikiran yang menentang status quo dan menawarkan perubahan-perubahan yang strategis, terutama dalam rangka menangani persoalan umat dan bangsa.

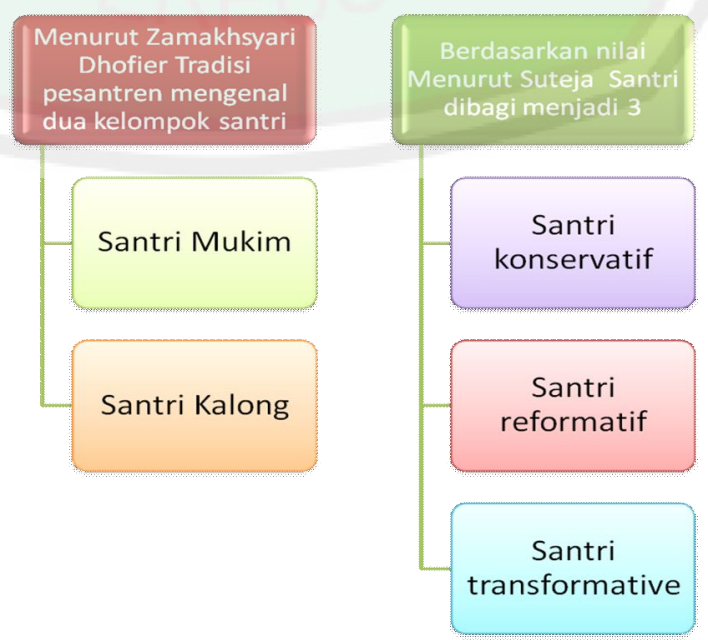

Skema 2.6 Pembagian Macam-macam Santri 


\section{e. Kiai}

Dalam beberapa kasus, kiai bukan hanya sebagai pendiri pesantren, tetapi sekaligus juga sebagai pemilik pesantren. Karena itu, kiranya logis jika dikatakan bahwa perkembangan pesantren sangat tergantung kepada para kiai selaku pendiri dan pemilik pesantren. Selain itu kiai tidak hanya bertugas sebagai guru agama dalam bentuk membaca kitab-kitab klasik, menjadi imam sholat wajib dan sholat jum'at, menjadi khatib, dan penasehat para santri, melainkan juga sekaligus sebagai pembimbing dalam mendirikan pesantren baru dan pengembangannya pada masa-masa berikutnya. Keberadaan seorang kiai dalam lingkungan sebuah pesantren laksana jantung bagi kehidupan manusia. Intensitas kiai memperlihatkan peran yang otoriter disebabkan karena kiailah perintis, pendiri, pengelola, pengasuh, pemimpin, dan bahkan juga pemilik tunggal sebuah pesantren. Oleh sebab alasan ketokohan kiai di atas, banyak pesantren akhirnya bubar lantaran ditinggal wafat kiainya. Sementara kiai tidak memiliki keturunan yang dapat melanjutkan usahanya. ${ }^{27}$

Sebagai salah satu unsur dominan dalam kehidupan sebuah pesantren, kiai mengatur irama perkembangan dan kelangsungan kehidupan suatu pesantren dengan keahlian, kedalaman ilmu, karismatik, dan ketrampilannya. $^{28}$ Sehingga tidak jarang sebuah

\footnotetext{
${ }^{27}$ Imam Bawani, Tradisionalisme dalam Pendidikan Islam, cet. ke-1 (Surabaya: al-Ikhlas, 1993), hlm. 90

${ }^{28}$ Hasbullah, Kapita Selekta Pendidikan Islam, cet. Ke-1, (Jakarta: Raja Grafindo Persada, 1996), hlm. 49
} 
pesantren tanpa memiliki manajemen pendidikan yang rapi. Segala sesuatu terletak pada kebijaksanaan dan keputusan kiai. ${ }^{29}$

Menariknya adalah bahwa hubungan kiai dan santri pada umumnya merupakan hubungan ketaatan yang tanpa batas. Memperhatikan hubungan kiai-santri ini terlihat jelas bahwa fungsi dan peran sosial pesantren terletak pada tiga hal, yaitu: (1) sebagai tempat terselenggaranya kegiatan transmisi dan transfer ilmu pengetahuan Islam, (2) sebagai pusat pemeliharaan tradisi Islam, (3) sebagai pusat penyiapan dan penciptaan kader-kader Islam. ${ }^{30}$

Paparan di atas memberikan penjelasan bahwa kiai mempunyai peran sentral di pesantren, selain kiai sebagai pediri, pembimbing serta pemilik pesantren, kiai juga sebagai guru agama, imam sholat, penasehat dan pembimbing, meski tanpa adanya sebuah manajemen tetapi tetap bisa beraktifitas dan menjalankan kegiatan pesantren dengan baik karena segala sesuatu terletak pada kebijaksanaan dan keputusan

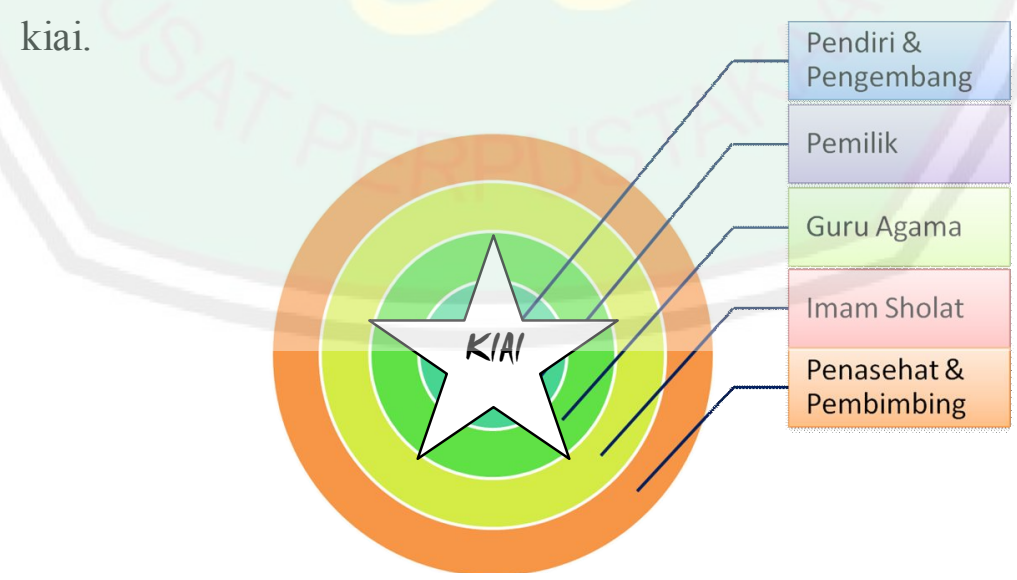

Skema 2.7 Peran Kiai di Pesantren

${ }^{29}$ A. Mukti Ali, Beberapa Persoalan Agama Dewasa Ini, cet. ke-1 (Jakarta: Rajawali Press, 1981), hlm. 23-24

${ }^{30}$ Azyumardi Azra, Surau: Pendidikan Islam Tradisional dalam Tradisi dan Modernisasi (Jakarta: Logos, 2003), hlm. 149 


\section{Tipe pesantren}

Dalam dinamikanya di masyarakat, pesantren mengalami perkembangan yang luar biasa. Pembagian pesantren beserta tipologinya sebagai berikut: ${ }^{31}$

a. Pesantren salafi

Jenis salafi merupakan jenis pesantren yang tetap mempertahankan pengajaran kitab-kitab Islam klasik sebagai inti pendidikannya. Di pesantren ini pengajaran pengetahuan umum tidak diberikan. Pemakaian sistem madrasah hanya untuk memudahkan sistem sorogan seperti yang dilakukan di lembaga-lembaga pengajaran bentuk lama. ${ }^{32}$ Pada umumnya pesantren dalam bentuk inilah yang menggunakan sistem sorogan dan weton.

b. Khalafi

Pesantren khalafi tampaknya menerima hal-hal baru yang dinilai baik di samping tetap mempertahankan tradisi lama yang baik. Pesantren sejenis ini mengajarkan pelajaran umum di madrasah dengan sistem klasikal dan membuka sekolah-sekolah umum di lingkungan pesantren. Tetapi pengajaran kitab Islam klasik masih tetap

${ }^{31}$ H M Jacub. Pondok Pesantren dan Pengembangan Masyarakat Desa (Bandung: Angkasa. 1981), hlm. 25 dalam Mufidah, Ch. Pesantren Rakyat (Malang: el Harakah Vol. 14 No. 1. 2012) hlm. 126

${ }^{32}$ Zul Asyri L.A., Nahdhatul Ulama Studi tentang Paham Keagamaan dan Upaya Pelestarianny Melalui Lembaga Pendidikan Pesantren, Disertasi (Jakarta: IAIN Syarif Hidayatullah, 1990), hlm. 187, dalam Yasmadi., Op., Cit, hlm. 70 
dipertahankan. Pesantren dalam bentuk ini diklasifikasikan sebagai pesantren modern dimana tradisi salaf sudah ditinggalkan sama sekali. ${ }^{33}$

\section{c. Pesantren kilat}

Pesantren kilat merupakan pesantren yang berbentuk semacam training dalam waktu relatif singkat dan biasa dilaksanakan pada waktu libur sekolah atau pada bulan ramadhan. Pesantren ini menitik beratkan pada keterampilan ibadah dan kepemimpinan. Sedangkan santri terdiri dari pelajar sekolah non pesantren yang dipandang perlu mengikuti kegiatan keagamaan di pesantren atau di sekolah-sekolah.

Di samping pembagian dan tipologi pesantren di atas, perkembangan lebih lanjut bermunculan pula corak dan istilah-istilah baru yang masih dalam koredor pesantren sebagai lembaga pendidikan Islam.

Diantara keragaman berdirinya pesantren dengan corak dan nama-nama tertentu dewasa ini adalah:

a. Pesantren terintegrasi

Corak pesantren ini lebih menekankan pada pendidikan vocasional (keterampilan) atau kejuruan sebagaimana balai latihan kerja di Departemen Tenaga Kerja dengan program yang terintegrasi. Sedangkan santri mayoritas berasal dari kalangan anak putus sekolah atau para pencari kerja. Alumni pesantren ini diharapkan menguasai ilmu keislaman juga memiliki keterampilan praktis dan kewirausahaan sebagai bekal kehidupan masa depannya.

${ }^{33}$ Ibid., hlm. 87-89 


\section{b. Pesantren Metal}

Pesantren metal yang bercorak kultur salafi, didirikan untuk memberikan pembinaan kepada kalangan muda yang ingin bertaubat dari kebiasaan minuman keras, narkoba, gila, pembinaan anak-anak jalanan dan patologi sosial lainnya.

Materi pembelajarannya hampir sama dengan pesantren pada umumnya yaitu menanamkan pendidikan agama, keterampilan (vocation) dan pengasuhan dengan pola-pola khusus. Sedangkan Metode pembelajarannya lebih menekankan pada komunikasi interaksi manusiawi oleh kiai untuk mengentaskan santri menjadi manusia normal dan kembali kepada masyarakatnya. Misalnya, pesantren metal dengan nama Pusat Komodo Militer Taubat Sunan Kalijaga di Desa Bulusari, Kecamatan Grandungmangu, Kabupaten Cilacap, Jawa Tengah; Pondok Pesantren Muslim Metal, Kecamatan Rejoso, Kabupaten Pasuruan, Jawa Timur.

c. Pesantren Alam

Pesantren yang dikelola mirip dengan pesantren kilat. Didirikan berawal dari hobi serta keinginan kuat untuk menjelajahi bumi Allah secara bebas. Belajar nilai-nilai Islam melalui fenomena alam. Aktivitasnya dikemas dengan istilah camping spiritual.

Materi di Pesantren Alam ini diajarkan tantangan, berjuang mengalahkan rintangan. Mengajak berfikir para santri bahwa betapa banyak nikmat Allah yang selalu bercurah kepada manusia. Materi 
pembelajarannya meliputi keIslaman, kepribadian, kepemimpinan, dan kecintaan terhadap lingkungan. Dengan menanamkan nilai-nilai Islam melalui alam ini diharapkan dapat menginternalisasikan nilai-nilai Islam untuk membentuk kekuatan karakter bagi seorang muslim dalam kehidupannya. Misalnya pesantren alam CIRIKO kepanjangan dari Cinta Rimba Kota, Dusun Cilame, Desa Sukamaju, Kecamatan Cigudeg, Kabupaten Bogor, Jawa Barat; Pesantren Alam Ma'rifatussalam, Pesantren Alam Desa Wisata Religius Buboho, Bango, Batuda Pantai, Gorontalo; Pesantren Alam al-Azhar, Cigombong, Sukabumi, Jawa Barat, dan sebagainya.

d. Pesantren Buruh Pabrik

Pesantren yang keberadaannya merupakan pelembagaan dari komunitas buruh pabrik yang ada di sekitar area industri. Pesantren ini merupakan respon dialog nilai-nilai keIslaman dengan modernisasi industrialisasi. Dengan maksud mencari solusi terhadap permasalahan sosial dikalangan buruh pabrik terutama tantangan sekulerisasi yang memerlukan penanganan khusus dalam pendekatan religious. Tumbuh dan berkembangnya pesantren ini adalah di sekitar Surabaya, Sidoarjo, Mojokerto dan Gresik. Pesantren Buruh Pabrik mengusung pendidikan seumur hidup, kurikulumny a juga fleksibel dengan prinsip bekerja sambil belajar atau belajar sambil bekerja. ${ }^{34}$

${ }^{34}$ Imam Bawani, Op., Cit, hlm. 123 


\section{e. Pesantren Rakyat}

Pesantren ini merupakan medan budaya nyantrinya kaum abangan. Jika ditelaah kembali tipologi masyarakat berdasarkan penelitian Geertz (1960) tipologi kaum abangan memiliki garis pemisah dengan kaum santri, namun dalam penelitian ini, kaum abangan yang hidup di dunia hitam penuh kemaksiatan dalam kenyataannya dapat dipertemukan dengan kaum santri meskipun santri dimaksud adalah santri pinggiran. Kekuatan kolaborasi ini terletak pada: pertama modal sosial yang dikembangkan melalui pendampingan secara istiqamah berorientasi pada pemberdayaan dan peningkatan serta pemerataan kesejahteraan; kedua medan budaya yang bernuansa tradisi lokal, kental dengan simbol-simbol kerakyatan sehingga menimbulkan rasa nyaman khususnya bagi santri abang ireng; ketiga pendekatan adaptatif, multi strategic, luwes dan berbasis kearifan local; keempat aktor pemimpinnya memiliki kredibelitas, integritas, komitmen kuat, istiqomah dalam berjuang serta mampu menjadi tokoh inspiratif bagi santrinya; dan kelima dukungan jejaring stakeholders menjadi akrab dan memiliki dedikasi yang tinggi dalam mengembangkan lembaga. ${ }^{35}$

Dilihat dari sudut pandang materi pembelajarannya, Pesantren Rakyat lebih dekat dengan kitab klasik ringan bagi santri khususnya santri inti. Dipandang dari aspek pemberdayaannya berorientasi pada vocational, pesantren ini mirip dengan pesantren integratif atau

${ }^{35}$ Ibid,. hlm. 131 
pesantren buruh pabrik yang berorientasi pada belajar seumur hidup, bekerja sambil belajar. $^{36}$

Dari sudut pandang basis santrinya dari kaum abangan yang berada di dunia hitam, Pesantren Rakyat hampir sama dengan Pesantren Metal dengan santri binaannya secara sosial tergolong berkebutuhan khusus, sedangkan jika dilihat dari aspek sistem pembelajaranya, metode pendekatan kultural, natural, partisipatif atau multi strategic terutama bagi kaum abang ireng, pesantren ini mengadaptasi strategi para wali khususnya Sunan Kalijaga dalam berdakwah menyebarkan agama Islam.

Jika dibandingkan dengan pondok pesantren pada umumnya, Pesantren Rakyat tidak memenuhi elemen-elemen lazimnya pondok pesantren, yaitu asrama (pondok), santri, pembelajaran kitab, kiai, dan masjid. Pesantren Rakyat, pesantrennya rakyat, hanya memenuhi dua unsur yaitu adanya santri dan pembelajaran kitab yang di dukung oleh ustadz ala kerakyatan. Selebihnya merupakan medan budaya yang diIslamkan tanpa mengurangi nuansa lokal yang masih mereka pertahankan. ${ }^{37}$ Namun tujuan akhir dakwah bil hal di kalangan masyarakat berkebutuhan khusus ini menjadi sebuah pesantren alternatif yang menginspirasi bagi kaum abangan di daerah lain di Indonesia.

\footnotetext{
${ }^{36}$ Imam Bawani, Pesantren Buruh Pabrik, Pemberdayaan Buruh Pabrik Berbasis Pendidikan Pesantren (Yogyakarta: LKIS, 2011), hlm. 87

${ }^{37}$ Zamakhsyari Dhofier, Op,. Cit, hlm. 39
} 
Kelima pesantren ini didirikan berdasarkan kebutuhan dan semangat memecahkan isu-isu sosial keagamaan di masyarakat bernuansa lokal. Sebab hanya diterapkan dalam kondisi tertentu dengan basis pembinaan spesifik dan metode pendekatan lebih lentur, mengalir secara alami. $^{38}$

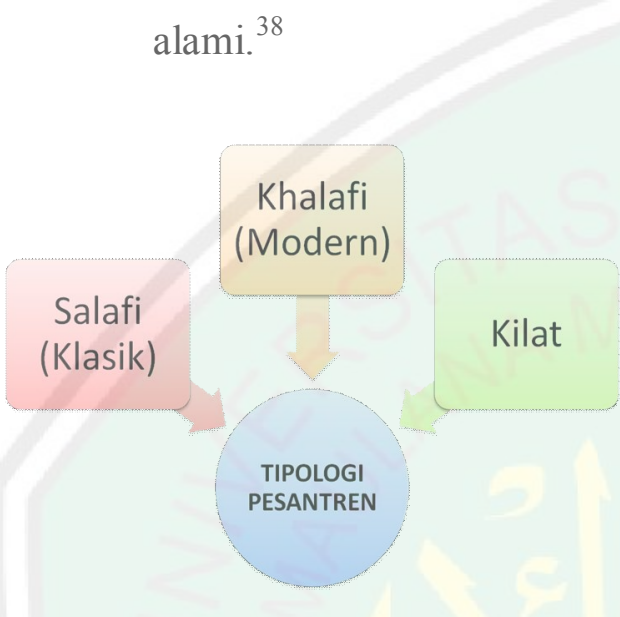

Skema 2.8 Tipologi pesantren

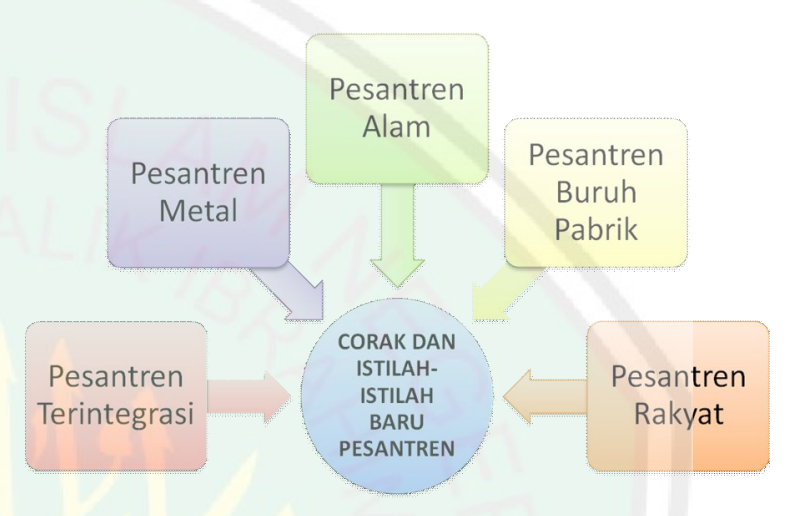

Skema 2.9 Corak dan Istilah-istilah Baru Pesantren

\section{Kurikulum Pesantren ${ }^{39}$}

Istilah kurikulum tidak ditemukan dalam kamus besar sebagian pesantren, terutama pada masa sebelum perang. Walaupun materinya ada di dalam praktek pengajaran, bimbingan rohani dan latihan kecakapan dalam kehidupan sehari-hari di pesantren, yang merupakan kesatuan dalam proses pendidikan di pesantren. Ini disebabkan karena memang pondok pesantren lama mempunyai kebiasaan untuk tidak merumuskan dasar dan tujuan pendidikannya secara eksplisit, ataupun meruncingkan secara tajam dalam bentuk kurikulum dengan rencana pelajarannya dan masa belajarnya.

\footnotetext{
${ }^{38}$ Mufidah, Ch. Op..Cit, hlm. 128

${ }^{39}$ Abdurrahman Wahid, dkk. Pesantren dan Pembaharuan. (Jakarta: LP3ES. 1988), hlm. 86-87
} 
Hal itu terbawa oleh sifat kesederhanaan pesantren, yang sesuai dengan dorongan berdirinya, dimana kiainya mengajar dan santrinya belajar, semata-mata untuk ibadah lillaahi ta'ala dan tidak pernah dihubungkan dengan tujuan tertentu dalam lapangan penghidupan dan tingkat dan jabatan tertentu dalam hirarki sosial atau birokrasi kepegawaian. Kalaupun ada target yang akan dicapai maka satu-satunya adalah tercapainya "title" MMAS (Mukmin, Muslim, Alim dan Shalih). Adapun mata pelajaran sebagian besar pesantren terbatas pada pemberian ilmu yang secara langsung membahas masalah 'aqidah, syari'ah, dan bahasa arab, antara lain: Al-Qur'an, dengan tajwid dan tafsirnya; aqaid dan ilmu kalam; figh dan ushul fiqh; hadits dengan mustholah hadits; bahasa Arab dengan ilmu alatnya seperti nahwu, sharaf, bayan, ma'ani, badi' dan arudl; tarikh; manthiq dan tasawuf. Dua materi terakhir ini biasanya diberikan pada pengajian tingkat lanjutan. Ada pula pesantren yang memberikan ilmu falak secara mendalam. Karena kiai adalah tokoh pokok dalam setiap pesantren, maka masing-masing pesantren memiliki keistimewaan sendiri-sendiri dalam bidang tertentu sesuai dengan keahlian masing-masing.

Kurikulum pesantren sebenarnya meliputi seluruh kegiatan yang dilakukan di pesantren selama sehari semalam (yang saat itu belum dirumuskan). Di luar pelajaran banyak kegiatan yang benilai pendidikan dilakukan di pondok berupa latihan hidup sederhana, mengatur kepentingan bersama, mengurusi kebutuhan sendiri, latihan bela diri, 
ibadah dengan tertib dan riyadlah. Di pondok lama, para santri sendiri yang mendirikan pondok baik dalam pembiayaan dan penukangannya (meskipun dibantu oleh tukang ahli), menanak nasi sendiri, mencuci pakaian dan mengatur kamar sendiri, mengatur keuangan sendiri bahkan ada santri yang membiayai diri sendiri dengan mengambil upah membantu masyarakat bertani atau membantu kiai dan kawan pesantrennya. Kehidupan di pesantren diatur oleh santri sendiri dengan aturan yang dibuat sendiri dan iuran yang ditetapkan sendiri. Hal lain yang penting, di pesantren biasanya para santri melakukan ibadah dengan tertib dan khusu', bahkan tidak sedikit yang melakukan riyadlah atas kehendak sendiri.

5. Metode dan Sistem Pengajaran di Pesantren ${ }^{40}$

Pesantren sebagai ruh, sunnah dan kehidupan berasrama dengan kiai sebagai tokoh pokoknya dan masjid sebagai pusat lembaganya, merupakan suatu sistem pendidikan yang tersendiri dan mempunyai corak khusus. Di dalam ruh, sunnah dan kehidupan berasrama itulah antara lain letak kekhususan pondok sebagai sistem pendidikan. Adapun metode pengajarannya sebenarnya adalah suatu hal yang setiap kali dapat berkembang dan berubah sesuai dengan penemuan metode yang lebih efektif dan efisien untuk mengajarkan masing-masing cabang ilmu pengetahuan. Meskipun demikian, dalam waktu yang sangat panjang pesantren secara agak seragam mempergunakan metode pengajaran yang

${ }^{40}$ Ibid.,hlm. 87-89 
lazim disebut sebagai weton dan sorogan. Beberapa pesantren tetap bertahan dengan metode pengajaran jenis itu, tanpa variasi ataupun perubahan. Metode pengajaran seperti itu merupakan sifat khas dari pesantren.

\section{Perkembangan dan perubahan kurikulum dan metode ${ }^{41}$}

Sementara beberapa pondok pesantren berjalan dengan segala tradisi yang diwarisinya secara turun temurun tanpa variasi dan perubahan, ada satu dua yang mencoba mencari jalan sendiri yang diharapkan akan menghasilkan lebih banyak dalam waktu yang lebih singkat. Pesantren semacam ini menyusun kurikulumnya berdasarkan pemikiran akan kebutuhan anak didik dan masyarakat. Untuk itu mereka mengintrodusir beberapa cabang ilmu pelengkap; seperti berhitung, sejarah, ilmu bumi, aljabar, ilmu ukur, ilmu alam, ilmu hayat, tatanegara dan beberapa bahasa asing. Metode weton dan sorogan mulai ditinggalkan atau didampingi dengan sistem madras atau klasikal dengan mempergunakan alat peraga, evaluasi dengan berbagai variasinya dan juga latihan-latihan. Prinsipprinsip psikologi perkembangan dalam pendidikan dan proses belajar mulai diterapkan, dan metode pengajaran baru pada masing-masing fakultas dipraktekkan. Kenaikan tingkat, pembagian kelas dan pembahasan masa belajar diadakan, sembari administrasi sekolah-pun dilaksanakan dalam organisasi yang tertib.

${ }^{41}$ Ibid,. hlm. 89-90 


\section{Keterpaduan dalam Sistem Pendidikan KeIslaman, KeIndonesiaan, dan Keilmuan}

Setelah Nurcholish Madjid menelaah terhadap dunia pendidikan Islam tradisional dan mempelajari pikiran-pikiran serta gagasangagasannya, nampaknya Nurcholish Madjid berobsesi menciptakan suatu sistem pendidikan yang memiliki keterpaduan antara unsur keIslaman, keindonesiaan, dan keilmuan. Sistem pendidikan terpadu ini diproyeksikan sebagai suatu alternatif untuk menuju masyarakat madani. Berikut ini akan dilihat konsep keterpaduan dalam ketiga unsur tersebut. ${ }^{42}$

\section{a. KeIslaman}

Islam sudah termarginalkan dalam bangunan sistem pendidikan, karena ada anggapan bahwa Islam sebagai penghambat kemajuan. Islam diklaim sebagai tatanan nilai yang tidak dapat hidup berdampingan dengan sains modern. Menurut Nurcholish Madjid, Islam yang dipandang sebagai penyebab kegagalan dan keterbelakangan adalah klaim-klaim warisan colonial yang pada masa dahulu digunakan sebagai alat untuk menghadapi sikap permusuhan non-koperatif kaum ulama', kiai, dan santrinya. Anggapan terhadap Islam sebagai musuh kemajuan dalam pandangan Nurcholish Madjid berarti orang itu tidak memahami keuniversalan ajaran Islam. Oleh sebab itu, penelaahan kembali terhadap ajaran nilai universalitas Islam amat diperlukan, ${ }^{43}$

\footnotetext{
${ }^{42}$ Yasmadi, Op..Cit. hlm. 121

${ }^{43}$ Nurcholish Madjid. Islam Doktrin dan Peradaban, Sebuah Telaah Kritis Tentang Masalah Keimanan, Kemanusiaan dan Kemodernan, cet. Ke-2 (Jakarta: Paramadina, 1992)
} 
sehingga dapat mengatasi sikap sebagian kalangan yang meninggalkan Islam.

Ajaran Islam dengan jelas menunjukkan adanya hubungan organik antara ilmu dan iman. Hubungan organik itu kemudian dibuktikan dalam sejarah Islam klasik ketika kaum muslim memiliki jiwa kosmopolit yang sejati. Atas dasar kosmopolitanisme itu umat Islam membangun peradaban dalam arti yang sebenar-benarnya yang juga berdimensi universal. ${ }^{44}$ Sebab pada dasarnya Islam itu membawa pada kemajuan bukan sebaliknya. Sejarah telah membuktikan, Islamlah yang membawa pada zaman kekuatan dan kegemilangan.

Inilah yang memperkokoh nilai universal Islam yang meliputi unsur sejarah, filsafat, sains, teologi dan tasawuf, sebagai tradisi keilmuan Islam klasik yang telah menaruh perhatian Nurcholish Madjid cukup tinggi. Keikutsertaan dunia pendidikan Islam secara aktif dalam pembangunan Indonesia akan menampilkan Indonesiadalam bentuk "baru". Nurcholish Madjid pernah mensinyalir bahwa Indonesia yang akan datang itu seperti sosok "santri yang canggih". Nurcholish Madjid menyelaraskan Indonesia dengan santri, karena pada dasarnya sosok santri itu sebagai tampilan sikap egaliter, terbuka, kosmopolit dan demokratis. Ini merupakan pola budaya pantai, sebab sekarang pola budaya pedalaman in land culture masih mendominasi. Dengan kata lain, suatu penampilan Islam modern yang menyerap secara konstruktif dan positif kehidupan modern, namun semuanya tetap dalam nilai-nilai

${ }^{44}$ Ibid,.hlm. 24 
keislaman. ${ }^{45}$ Dalam bahasa sederhana dan paling popular didengar adanya keselarasan antara iptek (ilmu pengetahuan dan teknologi) dan imtaq (iman dan taqwa). Dengan potensi inilah harapan akan terwujudnya masyarakat madani dapat dimungkinkan.

Perpaduan kedua komponen penunjang ipetek dan imtaq diupayakan lewat perpaduan dua sistem pendidika, tradisional dan modern. Memasukkan sistem pendidikan "baru" dalam dunia pendidikan Islam bukan berarti melepaskan yang "lama". Karena pada institusi pendidikan pesantren itu justru ada yang perlu ditumbuhkembangkan kembali. Tidak semua pada yang "lama" itu mesti dibuang. Nurcholish Madjid dalam hal ini menyerukan untuk melihat kembali kitab-kitab lama "klasik" untuk menyingkapi agar tidak terjadinya kemiskinan intelektual atau dalam istilah Nurcholish Madjid kehilangan jejak riwayat intelektualisme Islam. ${ }^{46}$

Tinggal lagi persoalan yang melilit dunia pendidikan sekarang adalah merumuskan kajian epistimologi ilmu-ilmu umum itu yang masih terlihat kabur, kemudian merumuskan metodologi dalam mengajarkannya di dunia pendidikan Islam secara umum. Konsep dasar yang dimunculkan Nurcholish Madjid sebatas bagaimana menempatkan kembali ilmu pengetahuan dan teknologi ke dalam daerah pengawasan nilai agama, moral dan etika. ${ }^{47}$ Karena pada prinsipnya, asal mula semua cabang ilmu pengetahuan adalah berpangkal pada ilmu agama.

\footnotetext{
${ }^{45}$ Hamid Hasan Bil Rami dan Sayid Ali Asyraf. Konsep Universitas Islam, terj. Machnun Husein, cet. ke-1, (Yogyakarta: Tiara Wacana Yogya, 1989), hlm. 14-21

${ }^{46}$ Nurcholish Madjid. Dialog Keterbukaan, Artikulasi Nilai-nilai Islam dalam Wacana Sosial Politik Kontemporer, cet. ke-1 (Jakarta: Paramadina, 1998). hlm. 262

${ }^{47}$ Ibid,. hlm. 247-248
} 
Ketika para intelektual muslim mampu mengembangkan dan mengIslamkan ilmu pengetahuan modern itu, dunia Islam akan dapat mencapai kemakmuran dalam berbagai bidang. Saat ini umat Islam hanya dapat menyaksikan bekas-bekasnya saja, sampai saat ini banyak sekali istilah-istilah teknis dalam ilmu pengetahuan dan teknologi modern di barat yang berasal dari bahasa Islam, khususnya bahasa Arab. Sebagai indikator, terdapat akar-akar Islam bagi ilmu pengetahuan dan teknologi modern. ${ }^{48}$ Peradaban Islam mempengaruhi Barat tidak hanya dalam bidang iptek, tetapi juga dalam bidang peradaban pada umumnya, maka dapat ditemukan pula berbagai istilah inggris pinjaman dari bahasa Arab dan Persia. ${ }^{49}$

Dengan menyadari kondisi umat Islam, dimana tingkat pendidikan modern rata-rata diseluruh dunia, masih lebih rendah dari bangsa-bangsa lain, maka untuk menuju kea rah masa depan yang lebih baik, Nurcholish Madjid menyerukan kepada umat Islam dalam merespon tantangan zaman itu harus terlebih dahulu dengan menangkap pesan dalam kitab suci. Kemudian secara kritis mempelajarai sosok ilmu pengetahuan yang dihasilkan oleh modernitas. Upaya ini merupakan salah satu upaya untuk menemukan kembali pengetahuan baru yang merupakan tujuan sejati intelektual Islam. ${ }^{50}$

\footnotetext{
${ }^{48}$ Nurcholish Madjid. Kaki Langit Peradaban Islam, cet. ke-1 (Jakarta: Paramadina, 1997). hlm. 17

${ }^{49}$ Ibid,. hlm. 17-18

${ }^{50}$ Nurcholish Madjid. Islam Doktrin,. Op. .Cit. hlm. 485-486
} 


\section{b. Keindonesiaan}

Modernisasi pendidikan diharapkan mampu menciptakan suatu lembaga pendidikan yang mempunyai identitas kultural yang lebih sejati sebagai konsep pendidikan masyarakat Indonesia baru yang di dalamnya juga akan ditemukan nilai-nilai universal Islam yang mampu melahirkan suatu peradaban masyarakat Indonesia masa depan. Di sisi lain, lembaga ini juga mencirikan keaslian indigenous Indonesia, karena secara kultural terlahir dari budaya Indonesia yang asli. Konsep inilah agaknya yang relevan dengan konsep pendidikan untuk menyongsong masyarakat madani.

Obsesi Nurcholish Madjid adalah mengupayakan modernisasi dengan tegas dan jelas berlandasan platform kemodernan yang berakar dalam keindonesiaan dengan dilandasi keimanan ${ }^{51}$ berkaitan dengan upaya modernisasi pendidikan di Indonesia, terbuka peluang kembali untuk melirik lembaga pesantren sebagai institusi pendidikan yang lahir dari budaya Indonesia yang asli. Sistem pendidikan colonial yang jauh berbeda dengan sistem pendidikan pesantren sangat tidak tepat untuk dijadikan model bagi pendidikan masa depan dalam rangka menyongsong Indonesia. Sejak awal kemunculannya sistem pendidikan colonial hanya terpusat pada pengetahuan dan keterampilan duniawi yaitu pendidikan umum. ${ }^{52}$

Komitmen Nurcholish Madjid dalam memodernisasi dunia pendidikan Islam Indonesia adalah kemodernan yang dibangun dan

${ }^{51} \mathrm{Ibid}, . \mathrm{hlm}, 485-486$

${ }^{52}$ Karel A. Streenbrink. Pesantren Madrasah Sekolah, Pendidikan Islam Dalam Kurun Modern (Jakarta: LP3ES, 1996). hlm. 24 
berakar dari kultur Indonesia serta dijiwai semangat keimanan. Maka untuk merekonstruksi institusi pendidikan tersebut perlu mempertimbangkan sistem pesantren yang mempertahankan tradisi belajar "kitab-kitab klasik" ditunjang dengan upaya internalisasi unsur keilmuan "modern". Pesantren dijadikan sebagai model awal, sebab disamping sebagai warisan budaya Indonesia, pesantren juga menyimpan potensi kekayaan khazanah Islam klasik yang terletak pada tradisi belajar kitab kuningnya.

Pesantren diharapkan dapat memberikan reponsi atas tuntutan era mendatang yang meliputi dua aspek, universal dan nasional. Aspek universal yaitu ilmu pengetahuan dan teknologi. Sedangkan dalam skala nasional yaitu pembangunan di Indonesia. Untuk yang terakhir ini, bahkan peran pesantren semakin besar dalam menentukan suatu pola pembangunan yang bersifat indigenous, asli sesuai aspirasi bangsa Indonesia sendiri, karena pesantren adalah sebuah lembaga sistem pendidikan-pengajaran asli Indonesia yang paling besar dan mengakar kuat. ${ }^{53}$ Tidak saja sebatas eksistensi pesantren sebagai kelembagaan pendidikan Islam, tetapi sejauhmana peranannya dalam memberikan landasan moril dan etika pada proses pembangunan yang sedang berjalan.

Pesantren dinilai mampu menciptakan dukungan sosial bagi pembangunan yang sedang berjalan. Sebab, pembangunan adalah suatu usaha perubahan sosial. Tujuannya adalah perbaikan dan peningkatan

${ }^{53}$ Ibid, hlm. 87-89 
kehidupan secara keseluruhan. Meskipun urgensi awalnya adalah tersirat dalam semboyan "cukup sandang, pangan, dan papan", tetapi, kaitannya luas sekali, seperti masalah perubahan sikap mental masyarakat dari agraris menjadi industry, penciptaan kesempatan kerja seimbang dengan pertumbuhan tenaga kerja yang ada, masalah demografis, masalah motivasi, juga menyangkut kondisi sosial masyarakat. $^{54}$

Atas dasar pertimbangan di atas, menurut Nurcholish Madjid, orangpun mulai membicarakan kemungkinan pesantren menjadi pola pendidikan nasional. Kemungkinan ini diperbesar dengan munculnya anggapan bahwa sistem pendidikan yang kini secara resmi berlaku adalah warisan pemerintah belanda, sebab masih mengandung cirri-ciri kolonial. Sistem ini tentulah bukan pilihan yang tepat dan layak untuk diterapkan di bumi Indonesia. ${ }^{55}$ Meskipun demikian, agaknya nilai positif yang diadopsi dan dikembangkan dari sistem ini adalah aspek keilmuan umum "modern" yang dimilkinya, sehingga akan terjadi perpaduan keilmuan.

\section{c. Keilmuan}

Persoalan mendasar yang terjadi hampir merata di dunia pendidikan kaum muslim kontemporer adalah terpisahnya lembagalembaga pendidikan yang memiliki konsentrasi dan orientasi yang berbeda. Ada lembaga yang menitikberatkan orientasinya pada "ilmuilmu modern" dan di sisi lain ada lembaga yang hanya menfokuskan

${ }_{55}^{54} \mathrm{Ibid}$.

${ }^{55}$ Ibid.hlm. 87 
diri pada "ilmu-ilmu tradisional". Realitas kelembagaan pendidikan ini lebih dikenal dengan dualise pendidikan.

Modernisasi pendidikan yang digagas oleh Nurcholish Madjid pada prinsipnya menghilangkan dualism pendidikan tersebut. Kedua bentuk lembaga itu sama-sama memiliki sisi positif yang patut dikembangkan dan juga mempunyai kelemahan yang sama sekali harus dibuang dan ditinggalkan. Usaha modernisasi Nurcholish Madjid tertuju pada upaya untuk mengkompromikan kedua lembaga ini dengan memadukan sisi baik antara keduanya, sehingga pada gilirannya akan melahirkan sistem pendidikan yang ideal. Nurcholish Madjid menyebutkan dengan sistem pendidikan Indonesia menuju kea rah titik temu atau konvergensi. ${ }^{56}$ Usaha ini berawal pada perpaduan unsurunsur keilmuan.

Upaya menghilangkan dualism pendidikan tersebut tidak terlepas dari usaha menghilangkan dikotomi keilmuan saat sekarang. Sebab, mengakarnya paham dikotomi keilmuan amat berpengaruh pada dinamika umat Islam itu sendiri. Pada masa kejayaan Islam, hampir tidak terlihat adanya dikotomi keilmuan antara "ilmu-ilmu umum" dan "ilmu-ilmu keislaman." ${ }^{\prime 57}$ Perkembangan ilmu pengetahuan berjalan demikian pesatnya, meliputi ilmu agama, bahasa, sejarah, aljabar, fisika, kedokteran, dan lain-lain. Tokoh-tokoh seperti Al-farabi, Ibnu Sina, Ikhwan Al-Shafa, dan lain-lain menyadari bahwa kesempurnaan

\footnotetext{
${ }^{56}$ Nurcholish Madjid. Tradisi Islam, Peran dan Fungsinya Dalam Pembangunan di Indonesia, cet. ke-1 (Jakarta: Paramadina, 1997). hlm. 22

${ }^{57}$ M. Athiyan Al-Abrasyi. Dasar-dasar Pokok Pendidikan Islam, terj. Bustami A. Gani dan Djohar Bahry, LIS., cet. ke-7 (Jakarta: Bulan Bintang, 1993), hlm. 167-172
} 
manusia hanya akan terwujud dengan penyerasian antara "ilmu-ilmu umum" dan "ilmu-ilmu keislaman", sebagai satu bagian yang tak terpisahkan dalam komponen keilmuan dalam Islam.

Sejarah pendidikan Islam telah menunjukkan bahwa keseimbangan antara ilmu-ilmu agama dan ilmu-ilmu dunia terdapat pada masa kejayaan dan kegemilangan Islam itu. Seperti diungkapkan oleh Hasan Langgulung, pakar pendidikan, keseimbangan ini tidaklah hilang kecuali pada zaman kelemahan. Jadi kelemahan dan kemunduran umat Islam bukan karena Islam, tetapi karena menjauhi Islam. ${ }^{58}$ Artinya umat Islam ketika itu tidak mau lagi menerima ilmu-ilmu modern yang bersumber dari barat.

Nurcholish Madjid sebagai seorang cendekiawan muslim yang banyak menangkap khazanah kekayaan Islam klasik menyadari keunggulan perpaduan keilmuan yang telah mengantarkan Islam pada era keemasan dan kemajuan itu. Sementara itu realitas dunia pendidikan Islam "pesantren" tradisional di Indonesia masih memperlihatkan keengganan untuk mengadopsi "ilmu-ilmu umum". Lembaga pendidikan ini mempertahankan aspek keilmuan Islam klasik saja. Aspek ini dari satu sisi punya nilai positif sebagai salah satu asset yang dimilkinya dan patut untuk dilirik kembali dalam membangun sistem pendidikan pada abad keruhanian ini. Untuk kelengkapannya pesantren perlu mengadopsi pengetahuan modern.

\footnotetext{
${ }^{58}$ Hasan Langgulung. Asas-asas Pendidikan Islam, cet. ke-2 (Jakarta: Mutiara Sumber Widia, 1992). hlm. 117
} 
Dengan demikian, sistem pendidikan "baru" yang digagas Nurcholish Madjid ini mengacu pada perpaduan kedua disiplin keilmuan tersebut. Dalam satu kesempatan Nurcholish Madjid mengatakan, dunia pendidikan Islam harus memodernisasi diri guna mengejar ketertinggalannya, dan untuk memenuhi tuntutan teknologi di masa depan. ${ }^{59}$ Pengalaman memperlihatkan bahwa untuk menguasai teknologi, dunia pesantren masih jauh kalah bersaing dibanding lembaga-lembaga pendidikan non pesantren yang telah lebih dahulu menguasai MIPA, sebagai salah satu prasyarat untuk menguasai teknologi. Dengan tidak mengatakan sama sekali tidak ada, karena perkembangan terakhir menunjukkan ada "pesantren khusus" yang menitikberatkan pada teknologi tertentu, seperti peternakan, pertanian, perikanan, dan lain-lain. Tetapi di samping jumlahnya yang relative sedikit, juga pertumbuhannya relative baru.

Institusi pendidikan Islam di masa mendatang mestinya tidak terkonsentrasi penuh pada bidang kajian Islam saja, lebih dari itu institusi pendidikan tersebut juga menaruh perhatian yang tinggi pada penguasaan bidang matematika, fisika, kimia, dan biologi (MIPA). Nurcholish Madjid mengatakan, bidang ini diperlukan untuk meningkatkan daya saing umat Islam demi menyongsong era teknologi dan era globalisasi mendatang. ${ }^{60}$

Pemikiran Nurcholish Madjid tersebut tertuju pada upaya untuk memasukkan kurikulum "umum" yang selama ini diterapkan di dunia

\footnotetext{
${ }^{59}$ Wawancara Nurcholish Madjid dengan Republika. Untuk Menguasai MIPA Lembaga Pendidikan Islam Mesti Memodernisasi Diri. Senin, 8 Maret 1999. hlm. 9

${ }^{60}$ Ibid,.
} 
pendidikan umum ke dalam pendidikan Islam yang telah mempunyai kurikulum tersendiri, sehingga yang akan terjadi nantinya kombinasi dua bentuk unsur keilmuan dalam skala yang utuh. Meskipun gagasan ini masih terlihat belum konkrit-sebab apakah mengacu pada sistem pendidikan terpadu dengan menggunakan kurikulum penuh atau hanya sekedar memberikan label Islam terhadap ilmu-ilmu umum, namun yang jelas obsesi Nurcholish Madjid adalah dengan perpaduan kedua unsur keilmuan diharapkan lahir manusia-manusia yang memiliki kekayaan intelektual, baik wawasan keislaman maupun wawasan ilmu sains modern. Inilah yang menjadi sasaran dan tujuan pendidikan Islam yang tercerminkan dalam penyusunan kurikulum. ${ }^{61}$

Latar belakang munculnya gagasan memadukan unsur keilmuan dalam modernisasi pendidikan Islam yang dilontarkan Nurcholish Madjid dapat dilihat dari dua faktor. Pertama berangkat dari ketidakpuasan yang berlebihan terhadap lembaga pendidikan yang selama ini hanya bergerak dibidang "ilmu-ilmu umum". Pendidikan dalam bentuk ini akhirnya melahirkan tenaga-tenaga terampil dalam disiplin keilmuan umum, bahkan tidak jarang menguasai iptek, namun memiliki jiwa yang kosong dari nilai-nilai moral. Sehingga peradaban yang diciptakan adalah peradaban yang tanpa dibarengi oleh nilai-nilai religious. Oleh sebab itu, konsep keterpaduan (keislaman, keindonesiaan) di atas merupakan solusi Nurcholish Madjid dalam rangka menyingkapi munculnya split personality (pribadi yang

\footnotetext{
${ }^{61}$ Jalaluddin dan Usman Said. Filsafat Pendidikan Islam Konsep dan Perkembangan, cet. ke-2 (Jakarta: Raja Grafindo Persada, 1996), hlm. 43
} 
pincang), sebagai akibat dari tidak kompleksnya unsur keilmuan dalam pendidikan. Konsep tersebut pada dasarnya juga merupakan usaha untuk mengkompromikan sistem pendidikan modern dengan sistem pendidikan tradisional.

Nurcholish Madjid dalam hal ini mengisyaratkan bahwa untuk menopang penataan dan pembenahan sistem pendidikan "pesantren" dituntut keseriusan dalam penggarapan yang diikuti dengan kejelasan program. Penggunaan metode yang komprehensif, kecakapan pelaksanaan, dan kelengkapan sasarannya. ${ }^{62}$ Dengan usaha yang serius ini diharapkan pendidikan mampu melahirkan manusia yang memiliki kesadaran yang tinggi dan juga memiliki kemampuan yang tinggi untuk mengadakan responsi terhadap tantangan-tantangan dan tuntutantuntutan hisup dalam konteks ruang dan waktu yang ada.

Konsep modernisasi pendidikan lebih menekankan aspek keterpaduan ketiga dimensi di atas dengan landasan historis dan filosofisnya. Dalam paradigma pemikiran Nurcholish Madjid, landasan historis modernisasi pendidikan Islam berangkat dari khazanah kejayaan masa Islam klasik. ${ }^{63}$

${ }_{62}^{62}$ Nurcholish Madjid. Bilik-biliki. Op,.Cit. hlm. 13

${ }^{63}$ Yasmadi, Op,.Cit. hlm. 140 


\section{BAB III}

\section{METODE PENELITIAN}

\section{A. Pendekatan dan Jenis Penelitian}

Berdasarkan judul yang diambil penulis, maka dalam penelitian ini penulis menggunakan pendekatan penelitian kualitatif deskriptif, karena studi ini lebih menekankan pada proses-proses sosial yang terjadi di Pesantren Rakyat Sumberpucung Kabupaten Malang, terutama terkait tentang segala sesuatu yang berhubungan dengan pengembangan sistem pendidikan Pesantren Rakyat.

Hal tersebut sesuai dengan ungkapan Kirk dan Miller yang dikutip oleh Moleong mendefinisikan bahwa penelitian kualitatif adalah tradisi tertentu dalam ilmu pengetahuan sosial yang secara fundamental bergantung pada pengamatan pada manusia, baik dalam kawasannya maupun dalam peristilahannya. ${ }^{1}$ Penelitian ini bertujuan untuk mendapatkan data/gambaran yang objektif, faktual, akurat, dan sistematis, mengenai pengembangan sistem pendidikan Pesantren Rakyat.

Metode penelitian kualitatif dibagi menjadi lima jenis, yaitu: Biografi, Fenomenologi, Grounded-theory, Etnografi dan Studi Kasus. ${ }^{2}$ Dalam penelitian ini peneliti menggunakan jenis penelitian studi kasus dengan alasan karena studi ini dilakukan terhadap suatu kesatuan sistem, yang berupa program, kegiatan, peristiwa, atau sekelompok individu yang terikat oleh

\footnotetext{
${ }^{1}$ Lexy J. Moleong, Metode Penelitian Kualitatif (Bandung: PT Remaja Rosdakarya, 2005), hlm. 4 ${ }^{2}$ John W Creswell, Qualitative Inquiry and Research Design; Choosing Among Five Traditions, Thousand Oaks, CA: Sage, 1998. Hlm. 6
} 
tempat, waktu, atau ikatan tertentu, ${ }^{3}$ yaitu Pesantren Rakyat Al-Amin Sumberpucung Kabupaten Malang. Lebih rinci studi kasus merupakan penelitian eksplorasi dan memainkan peranan yang amat penting dalam menciptakan hipotesis atau pemahaman orang tentang berbagai variabel sosial. Sehingga format studi kasus ini lebih tepat apabila digunakan untuk meneliti masalah-masalah yang membutuhkan studi mendalam, seperti masalah tingkah laku konsumen suatu produk; masalah efek media terhadap pemirsa terhadap suatu tayangan media; permasalahan permasalahan implementasi kebijakan publik di masyarakat; dan sebagainya. ${ }^{4}$ Dengan demikian, analisis isi di sini menekankan pada studi terhadap peristiwa model Pesantren Rakyat.

\section{B. Kehadiran Peneliti}

Dalam penelitian ini, peneliti bertindak sebagai instrumen aktif dalam upaya mengumpulkan data-data di lapangan. Sedangkan instrumen pengumpulan data selain manusia adalah berbagai bentuk alat-alat bantu seperti kamera untuk mengambil gambar kegiatan, Hp untuk merekam keteranagan informan disaat wawancara, dan berupa dokumen-dokumen lainnya yang dapat digunakan untuk menunjang keabsahan hasil penelitian, namun hanya sebagai instrument pendukung.

Kehadiran dan keterlibatan peneliti untuk menemukan makna dan tafsiran tidak dapat digantikan oleh orang lain, sebab hanya peneliti yang dapat mengkonfirmasikan dan mengadakan pengecekan. Oleh karena itu

\footnotetext{
${ }^{3}$ Robert E. Stake, “Case Studies”, dalam Norman K. Denzin \& Yvonna S. Lincoln (ed.), Handbook of Qualitative Research (London: Sage Publications, 1994), hlm. 236

${ }^{4}$ Burhan Bungin, Penelitian Kualitatif, Jakarta: Kencana. 2007, hlm. 69
} 
peneliti berusaha semaksimal mungkin untuk hadir dan terlibat langsung dalam kegiatan yang ada di lokasi penelitian yaitu Pesantren Rakyat Al-Amin Sumberpucung Kabupaten Malang. Sebagai peneliti, maka peneliti di sini berusaha menyesuaikan diri, mendasarkan diri atas perluasan pengetahuan, memproses data secepatnya serta memanfaatkan kesempatan untuk mengklarifikasi dan mengamati model Pesantren Rakyat Al-amin Sumberpucung Kabupaten Malang.

Peneliti memulai ke lapangan terhitung sejak peneliti mengetahui adanya Peantren Rakyat Al-Amin, namun keajekan penelitian dilakukan pada saat peneliti melakukan konfirmasi dan survey kedua kalinya pada saat penyusunan proposal tesis yaitu pada tanggal 7 Januari 2013 di Pesantren Rakyat Al-Amin Sumberpucung Kabupaten Malang. Setelah ujian proposal, kemudian peneliti melaksanakan penelitian di Pesantren Rakyat Al-Amin dengan mengikuti kegiatan yang diselenggarakan dan bermalam di sana, terhitung mulai tanggal 16 Februari sampai 17 Februari 2013.

Dalam proses pemilihan informan, peneliti menggunakan teknik purposive sampling, yaitu peneliti memilih orang yang dianggap mengetahui secara jelas permasalahan yang diteliti. Kehadiran peneliti di lapangan dalam rangka menggali informasi menggunakan tahapan sebagai berikut:

1. Pemilihan informan awal, peneliti memilih informan yang menurut peneliti memiliki informasi memadai berkenaan dengan model Pesantren Rakyat Al-amin Sumberpucung Kabupaten Malang, yaitu kiai Pesantren Rakyat, Lurah Pesantren Rakyat, Pendidik (ustadz) Pesantren Rakyat, dan santri Pesantren Rakyat. 
2. Pemilihan informan lanjutan, peneliti ingin memperluas informasi yang berhubungan dengan model Pesantren Rakyat Al-Amin Sumberpucung Kabupaten Malang. Apabila sudah tidak ada lagi informasi baru yang relevan dengan informasi sebelumnya maka hal ini tidak dilakukan.

\section{Lokasi Penelitian}

Dalam penelitian ini, peneliti memilih Pesantren Rakyat Al-Amin Sumberpucung Kabupaten Malang sebagai lokasi penelitian. Pesantren Rakyat Al-Amin terletak di Desa selatan stasiun Sumberpucung Kabupaten Malang, Jl. Kopral Suradi RT:07/RW:01 Sumberpucung (65165).

Alasan utama yang melatarbelakangi penelitian di Pesantren Rakyat Al-Amin Sumberpucung Kabupaten Malang sebagai lokasi penelitian adalah sebagai berikut.

1. Pesantren Rakyat merupakan institusi pendidikan Islam yang menekankan pada kesederhanaan, pembinaan akhlak, serta menonjolkan aplikasi dari pada teori.

2. Pesantren Rakyat memiliki keunikan pesantren, santri yang belajar tanpa mengeluarkan biaya, namun pesantren ini mampu merangkul semua kalangan, di sana masyarakatnya plural atau heterogen baik agamanya, pekerjaannya, budayanya dan kebiasaanya, mulai dari orang abangan, mabuk-mabukan, judi, prostitusi sampai pejabat. Pesantren ini tidak mengenal usia, baik muda maupun tua, menampung semuanya tanpa pilah-pilih dan tanpa pandang bulu selama mereka mengaku rakyat maka mereka adalah santri Pesantren Rakyat. 
3. Keunikan pendidikannya yang tiada batasan usia,kalangan elit maupun alit, inilah yang nantinya akan membantu menjawab tantangan dan problematika pendidikan selama ini, seperti mahalnya biaya pendidikan merupakan momok bagi masyarakat yang notabennya dari keluarga miskin atau kurang mampu.

\section{Data dan Sumber Data}

Data adalah informasi yang dikatakan oleh manusia yang menjadi subjek penelitian, hasil observasi, fakta-fakta, dokumen yang sesuai dengan fokus penelitian. Informasi dari subjek penelitian dapat diperoleh secara verbal melalui wawancara atau dalam bentuk tertulis melalui analisa dokumen. ${ }^{5}$ Dan menurut cara memperolehnya data dikelompokkan menjadi dua macam, yaitu data primer dan data sekunder. Data primer adalah data yang diperoleh dari sumbernya secara langsung, diamati dan dicatat secara langsung, seperti observasi, wawancara, dan dokumentasi dengan pihak yang terkait, khususnya pimpinan/kiai Pesantren Rakyat Sumberpucung Kabupaten Malang, pendidik Pesantren Rakyat, santri Pesantren Rakyat, rakyat sekitar Pesantren Rakyat Al-Amin Sumberpucung Kabupaten Malang dan semua elemen yang bersangkutan dengan Pesantren Rakyat Al-Amin Sumberpucung Kabupaten Malang. Sedangkan data sekunder adalah data yag dikumpulkan, diolah, dan disajikan oleh pihak lain yang biasanya dalam bentuk publikasi dan di jurnal ${ }^{6}$. Hubungan peneliti dan informan sangat ditentukan oleh sejauh

\footnotetext{
${ }^{5}$ Rulam Ahmadi. Memahami Metodologi Penelitian Kualitatif(Malang: UIN Malang Press, 2005), hlm. 63

${ }^{6}$ Hadari Nawawi dan Mimi Martini. Penelitian terapan (Yogyakarta: Gajah Mada University Press, 1994), hlm. 73
} 
mana kemampuan dan keterampilan komunikasi yang dibina peneliti sejak awal menjajaki lokasi penelitian.

Hasil wawancara dengan kiai Pesantren Rakyat, lurah Pesantren Rakyat, ustadz Pesantren Rakyat, serta santri Pesantren Rakyat diolah dan dikumpulkan dengan dokumen-dokumen Pesantren Rakyat, khususnya dokumen-dokumen pendukung dalam model Pesantren Rakyat Al-Amin serta hasil observasi yang peneliti lakukan.

\section{E. Teknik Pengumpulan Data}

Agar pengumpulan data dan informasi berjalan lebih efektif dan efesien, pelaksanaan pengumpulan data di lapangan diatur melalui strategi sebagai berikut:

Bagaimana model Pesantren Rakyat Al-Amin di Sumberpucung Kabupaten Malang?

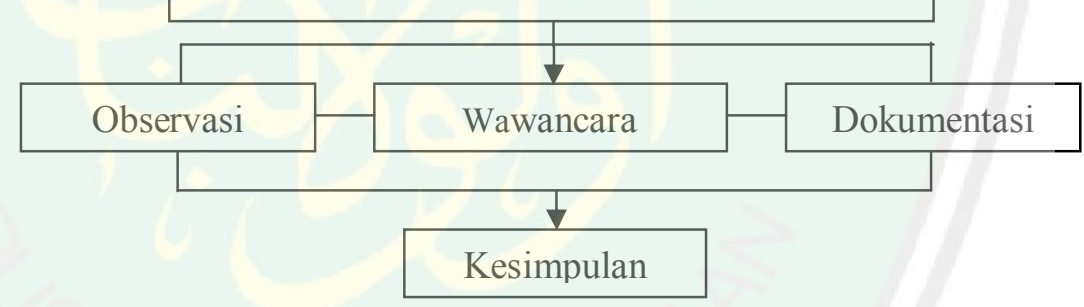

Skema 3.1 Fokus Penelitian

1. Observasi

Observasi atau pengamatan merupakan salah satu teknik atau cara mengumpulkan data dengan jalan mengadakan pengamatan terhadap kegiatan yang sedang berlangsung. Observasi dapat dilakukan secara partisipatif atau nonpartisipatif. Dalam observasi partisipatif (partispatory pobservation), pengamat ikut serta dalam kegiatan yang sedang berlangsung yakni pada kegiatan yang dilaksanakan. Sedangkan dalam observasi nonpartisipatif (nonparticipatory observation), pengamat tidak 
ikut serta dalam kegiatan, peneliti hanya berperan mengamati kegiatan. ${ }^{7}$ Dari beberapa teknik observasi tersebut, peneliti menggunakan observasi partisipan, jadi pengamat ikut serta dalam kegiatan yang berlangsung di Pesantren Rakyat Al-Amin, observasi ini dilakukan sebelum ujian proposal tesis tepatnya pada tanggal 1 Februari 2013. Observasi dilakukan selama 2 kali kehadiran peneliti di lokasi penelitian. Yaitu pada kegiatan pembelajaran, kegiatan jagong maton yang merupakan salah satu strategi internalisasi nilai karakter pada santri.

Hal-hal yang diamati antara lain: (1) Keadaan fisik, meliputi situasi lingkungan Pesantren Rakyat serta sarana yang menunjang untuk pengembangan sistem pendidikan pesantren; (2) Pelaku yang terlibat di Pesantren Rakyat; (3) Model pesantren mulai dari proses pembelajaran sehingga terlihat bagaimana strategi yang digunakan; (4) Kegiatan atau aktivitas penunjang yang berpengaruh terhadap model Pesantren Rakyat Al-Amin di Sumberpucung Kabupaten Malang.

2. Wawancara

Wawancara merupakan percakapan dengan maksud tertentu. Percakapan itu dilakukan oleh dua pihak, yaitu pewawancara (interviewer) yang mengajukan pertanyaan dan terwawancara yang memberikan jawaban atas pertanyaan itu. ${ }^{8}$ Dengan tujuan untuk mendapatkan gambaran

\footnotetext{
${ }^{7}$ Nana Syaodih Sukmadinata. Metode Penelitian Pendidikan (Bandung: Remaja Rosdakarya, 2007), hlm. 220

${ }^{8}$ S. Margono, Metodologi Penelitian Pendidikan (Jakarta: PT Rineka Cipta, 2007), hlm. 186
} 
lengkap tentang topik yang diteliti. ${ }^{9}$ Dengan kata lain bahwa wawancara merupakan teknik pengumpulan data yang utama.

Isi wawancara mengenai: (1) Pengalaman informan, yakni apa yang dikerjakan; (2) Pendapat, pandangan, tanggapan, tafsiran atau sudut pandang tentang Pesantren Rakyat Al-Amin; pada pertanyaan ini juga menyangkut tentang komponen-komponen yang ada di Pesantren Rakyat Al-Amin (3) Perasaan adanya Pesantren Rakyat Al-Amin;

Pengetahuan, fakta-fakta yang diketahui tentang Pesantren Rakyat AlAmin.

Ditinjau dari pelaksanannya, interview dibedakan atas: (1) Interview bebas (Innguided Interview); (2) Interview terpimpin, guided interview; (3) Interview bebas terpimpin, yaitu kombinasi antara interview bebas dan interview terpimpin. ${ }^{10}$ Dari ketiga jenis tersebut, penulis menggunakan wawancara Interview bebas terpimpin, dengan pertimbangan sebagai berikut:

a. Dengan interview terpimpin dapat dipersiapkan sedemikian rupa pertanyaan-pertanyaan yang diperlukan agar hanya fokus mengulas pokok-pokok permasalahan yang akan diteliti.

b. Dengan Interview bebas diharapkan akan tercipta nuansa dialog yang lebih akrab dan terbuka sehingga diharapkan data yang didapatkan valid dan mendalam. Metode ini digunakan untuk memperoleh data tentang;

\footnotetext{
${ }^{9}$ Burhan Bungin (Ed.). Metodologi Penelitian Kualitatif Aktualisasi Metodologis ke Arah Ragam Varian Kontempoter (Jakarta: Raja Grafindo Persada, 2007), hlm. 157

${ }^{10}$ Hamidi, Metode Penelitian Kualitatif Aplikasi Praktis Pembuatan Proposal dan Laporan Penelitian (Malang: UMM Press, 2005), hlm. 156
} 
bagaimana pengembangan sistem pendidikan pesantren berbasis Rakyat.

Pertanyaan tentang fokus penelitian ditujukan kepada: (1) Kiai Pesantren Rakyat Al-Amin Sumberpucung Kabupaten Malang; (2) Lurah Pesantren Rakyat Al-Amin Sumberpucung Kabupaten Malang; (3) Pendidik (ustadz) Pesantren Rakyat Al-Amin Sumberpucung Kabupaten Malang; (4) Santri (peserta didik) Pesantren Rakyat Al-Amin Sumberpucung Kabupaten Malang, dan (5) Semua elemen yang berhubungan dengan model Pesantren Rakyat Al-Amin Sumberpucung Kabupaten Malang.

Kiai Pesantren Rakyat mempunyai peranan yang penting karena kiai merupakan penanggungjawab penuh lembaga. Kiai menjadi informan dalam penelitian sehubungan dengan pengembangan sistem pendidikan Pesantren Rakyat yang diterapkan, yang kemudian dilaksanakan oleh seluruh warga Pesantren Rakyat terutama terkait pelaksanaan pendidikan di Pesantren Rakyat Al-Amin Sumberpucung Kabupaten Malang, dan kiai Pesantren Rakyat ini menjadi sumber utama dalam penelitian ini, sebagai sumber utama, peneliti banyak melakukan wawancara dengan kiai Pesantren Rakyat ini untuk mendapatkan informasi yang luas dan komprehensif. Hal ini dikarenakan kiai memegang peranan penting dalam memberi binaan untuk menjalankan kegiatan sehingga tujuan yang diharapkan dapat tercapai secara maksimal.

Selain itu informan berikutnya yaitu lurah dan ustadz Pesantren Rakyat Al-Amin. Lurah dan ustadz Pesantren Rakyat Al-Amin berperan 
penting dalam membantu kiai untuk memperlancar dan mencapai tujuan pendidikan serta tujuan yang ada di Pesantren Rakyat Al-Amin.

Informan selanjutnya yaitu santri Pesantren Rakyat Al-Amin. Santri juga mempunyai peran penting dalam kegiatan pembelajaran sehingga pengembangan sistem pendidikan Pesantren Rakyat Al-Amin juga disesuaikan dengan karakteristik dan kondisi santri sebagai peserta didik.

Hasil wawancara dengan kiai, lurah, ustadz serta santri Pesantren Rakyat Al-Amin diolah dan dikumpulkan dengan dokumen-dokumen Pesantren Rakyat Al-Amin khususnya dokumen-dokumen model Pesantren Rakyat Al-Amin yang berupa dokumen para ustadz, macam kegiatan, sarana prasarana, serta bidang dan sasaran Pesantren Rakyat AlAmin.

Peneliti berkoordinasi terlebih dahulu dengan kiai Pesantren Rakyat Al-Amin dalam menentukan informan yang dapat memberikan informasi terkait fokus penelitian. Berdasarkan hasil koordinasim penentuan informan di Pesantren Rakyat yaitu (1) Kiai Pesantren Rakyat Al-Amin Sumberpucung Kabupaten Malang; (2) Lurah Pesantren Rakyat Al-Amin Sumberpucung Kabupaten Malang; (3) Pendidik (ustadz) Pesantren Rakyat Al-Amin Sumberpucung Kabupaten Malang; (4) Santri (peserta didik) Pesantren Rakyat Al-Amin Sumberpucung Kabupaten Malang, dan (5) Semua elemen yang berhubungan dengan model Pesantren Rakyat Al-Amin di Sumberpucung Kabupaten Malang. 
Sedangkan untuk memudahkan pemahaman dari hasil penelitian ini, maka penulis paparkan pengkodean dalam teknik pengumpulan data dan sekaligus pengkodean informannya.

\section{Dokumentasi}

Pengguanaan dokumen merupakan teknik pengumpulan data yang bersumber dari non-manusia. Data-data yang bersumber dari non-manusia merupakan sesuatu yang sudah ada, sehingga peneliti tinggal memanfaatkannya untuk melengkapi data-data yang diperoleh melalui pengamatan atau observasi dan wawancara. Dokumen ada dua macam yaitu dokumen pribadi (buku harian, surat pribadi, dan autobiografi) dan dokumen resmi (memo, pengumuman, instruksi, aturan suatu lembaga, majalah, buletin, pernyataan dan berita yang disiarkan oleh media masa) ${ }^{11}$

Lincoln dan Guba membedakan data yang bersumber dari nonmanusia menjadi dua kategori, dokumen dan rekaman. Rekaman adalah semua jenis pernyataan tertulis yang dibuat oleh dan untuk seseorang atau lembaga dengan tujuan untuk kepentingan pertanggungjawaban. Penggunaan dokumen sebagai data penelitian kualitatif didasari oleh pemikiran bahwa data yang diperoleh peneliti melalui teknik pengamatan dan wawancara belum dapat merekam semua data yang dibutuhkan. Untuk itu peneliti berkepentingan memperkaya informasi dari data-data yang bersumber dari non-manusia ${ }^{12}$

Peneliti menghimpun dokumen-dokumen antara lain profil Pesantren Rakyat (sejarah), struktur organisasi, data santri, data asatidz,

\footnotetext{
${ }^{11}$ Lexy Moleng. Metodologi Penelitian Kualitatif(Bandung: Remaja Rosdakarya, 2006), hlm. 216 ${ }^{12}$ Lincoln Y.S and A.G. Guba. Naturalistic Inquiry (Beverly Hils: Sago Publication, 1985), hlm. 23
} 
sarana prasarana, serta data-data lain yang mendukung. Selain itu peneliti juga mengumpulkan dokumen foto kegiatan-kegiatan penelitian yang peneliti lakukan di Pesantren Rakyat Al-Amin Sumberpucung Kabupaten Malang.

Dokumen yang diperlukan bisa dilihat melalui tabel berikut:

Tabel 3.1

Dokumentasi yang diperlukan dalam Penelitian

\begin{tabular}{|c|c|c|}
\hline No & Jenis Dokumen & Rincian Dokumen \\
\hline \multirow{6}{*}{1} & \multirow{6}{*}{ Profil Lembaga } & a. Sejarah Berdiri \\
\hline & & b. Visi, Misi, dan Tujuan \\
\hline & & c. Struktur Organisasi \\
\hline & & d. Data Santri \\
\hline & & e. Data Pendidik (Ustadz) \\
\hline & & f. Sarana Prasarana \\
\hline \multirow{3}{*}{2} & \multirow{3}{*}{ Kegiatan Pesantren Rakyat } & $\begin{array}{l}\text { a. Bidang dan sasaran Pesantren } \\
\text { Rakyat Sumberpucung Kabupaten } \\
\text { Malang }\end{array}$ \\
\hline & & $\begin{array}{l}\text { b. Aktivitas/kegiatan Pesantren } \\
\text { Rakyat Sumberpucung Kabupaten } \\
\text { Malang }\end{array}$ \\
\hline & & $\begin{array}{l}\text { c. Pengelolaan dan penyelenggaraan } \\
\text { Pendidikan di Pesantren Rakyat }\end{array}$ \\
\hline \multirow[b]{2}{*}{3} & \multirow[b]{2}{*}{ Foto-foto Kegiatan } & a. Foto kegiatan Pesantren Rakyat \\
\hline & & $\begin{array}{l}\text { b. Foto peneliti bersama kiai } \\
\text { Pesantren Rakyat, lurah, ustadz, } \\
\text { dan santri Pesantren Rakyat }\end{array}$ \\
\hline
\end{tabular}

Peneliti haruslah mampu menelaah rekaman dan dokumen mengenai pengembangan sistem pendidikan Pesantren Rakyat Al-Amin di 
Sumberpucung Kabupaten Malang, sehingga ditemukan hasil penelitian yang sesuai dengan fokus penelitian.

\section{F. Teknik Analisis Data}

Analisa Data adalah proses mengorganisasikan dan mengurutkan data ke dalam pola, kategori, dan satuan uraian dasar, sehingga dapat ditemukan tema dan dapat dirumuskan hipotesis kerja seperti disarankan data. ${ }^{13}$

Merujuk pada pandangan Miles dan Huberman tentang analisis kualitatif, bahwa: Pertama data yang muncul berwujud kata-kata dan bukan rangkaian angka. Data itu mungkin telah dikumpulkan dalam aneka macam cara (observasi, wawancara, intisari dokumen, pita rekaman), dan biasanya “diproses" kira-kira sebelum siap digunakan (melalui pencatatan, pengetikan, penyuntingan, atau alih tulis), tetapi analisis kualitataif tetap menggunakan kata-kata, yang biasanya disusun kedalam teks yang diperluas. Mereka menganggap bahwa analisis kualitatif terdiri dari tiga alur kegiatan yang terjadi secara bersamaan yaitu: reduksi data, penyajian data, penarikan kesimpulan atau verifikasi. ${ }^{14}$ Hal ini sebagaimana digambarkan dalam gambar sebagai berikut:

\footnotetext{
${ }^{13}$ Lexy J. Moleong, Metode Penelitian Kualitatif (Bandung: PT Remaja Rosdakarya 2007), hlm. 280

${ }^{14}$ Miles dan Huberman, Analisis Data Kualitatif, sebagaimana yang dikutip oleh Wahid Murni, Cara Mudah Menulis Proposal dan Laporan Penelitian Lapangan (Malang: UM Press, 2008), hlm. 53
} 
Gambar 3.1

Komponen-komponen Analisis Data: Model Alir

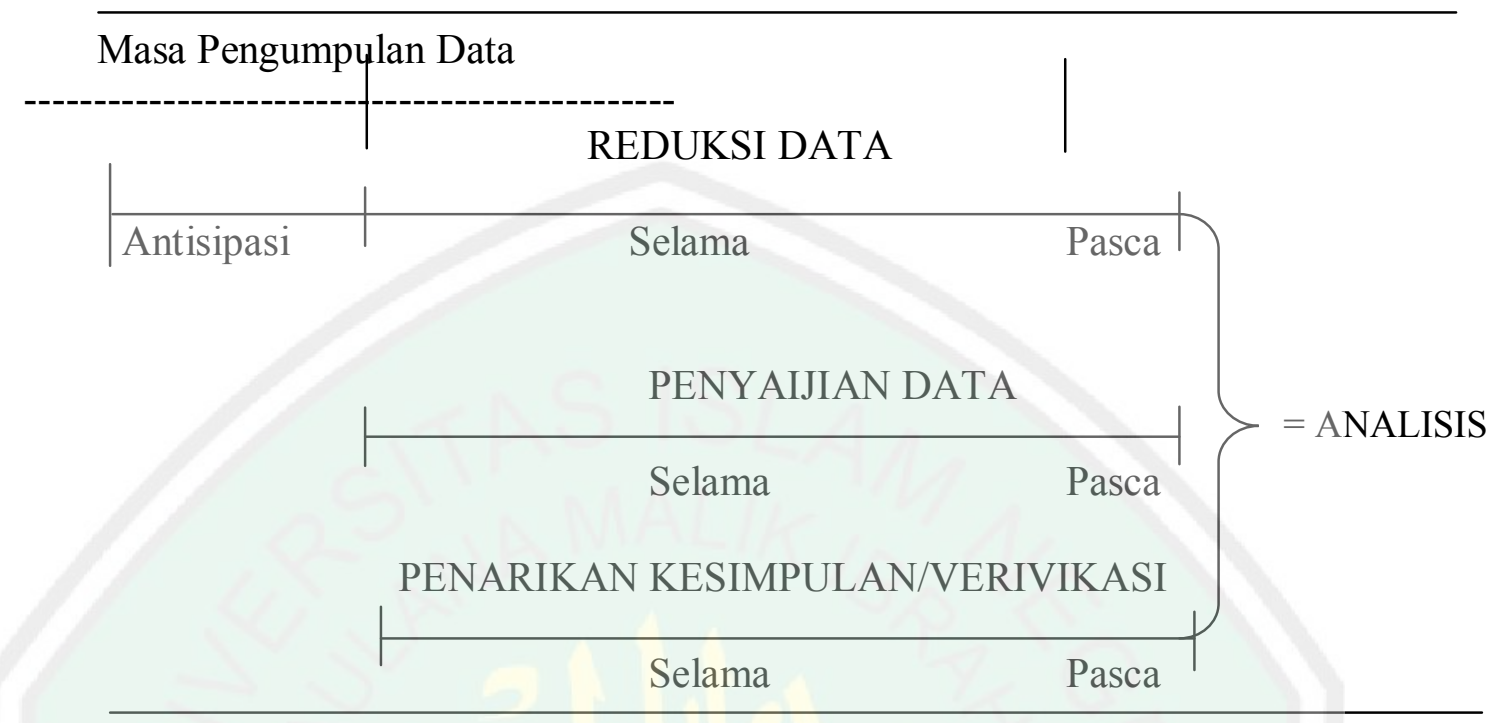

Teknik análisis data model alir dalam penelitian ini dijelaskan sebagaimana langkah-langkah berikut:

1. Pengumpulan Data

Kegiatan pengumpulan data dilakukan sejak peneliti memasuki lokasi penelitian sampai semua data yang diperlukan terkumpul. Pengumpulan data diperoleh dari hasil observasi partisipan, wawancara bebas terpimpin, dan dokumen.

2. Reduksi Data

Kegiatan yang dilakukan pada tahap ini adalah mengidentifikasi data dan mengkode data. Dalam pengkodean data digunakan tiga kolom yang terdiri dari nomor, aspek pengkodean, dan kode. Untuk lebih jelasnya perhatikan tabel berikut: 
Tabel 3.2

Pengkodingan

\begin{tabular}{|c|c|c|}
\hline No & Aspek Pengkodean & Kode \\
\hline \multirow{5}{*}{1} & Teknik Pengumpulan Data & \\
\hline & a. Wawancara & $\mathrm{W}$ \\
\hline & b. Observasi & $\mathrm{O}$ \\
\hline & c. Dokumentasi & $\mathrm{D}$ \\
\hline & d. Pesantren Rakyat Al-Amin Sumberpucung & PRS \\
\hline \multirow{7}{*}{2} & Sumber Data & \\
\hline & a. Kiai Pesantren Rakyat Al-Amin Sumberpucung & KPRS \\
\hline & b. Lurah Pesantren Rakyat Al-Amin Sumberpucung & LPRS \\
\hline & c. Ustadz Pesantren Rakyat Al-Amin Sumberpucung & UPRS \\
\hline & d. Santri Pesantren Rakyat Al-Amin Sumberpucung & SPRS \\
\hline & $\begin{array}{l}\text { e. Santri } 2 \text { Pesantren Rakyat Al-Amin } \\
\text { Sumberpucung }\end{array}$ & SPRS2 \\
\hline & f. Masyarakat Pesantren Rakyat Sumberpucung & MPRS \\
\hline \multirow[b]{2}{*}{3} & Fokus Penelitian & \\
\hline & $\begin{array}{l}\text { Pengembangan Sistem Pendidikan Pesantren Rakyat } \\
\text { Sumberpucung }\end{array}$ & $\mathrm{F}$ \\
\hline
\end{tabular}

3. Penyajian data

Pada tahap ini adalah mengorganisasikan data yang sudah direduksi. Data tersebut mula-mula disajikan secara terpisah antara satu tahap dengan tahapan yang lain tetapi setelah kategori terakhir direduksi, maka keseluruhan data dirangkum dan disajikan secara terpadu. Proses ini dilakukan dengan cara membuat tabel dan skema sehingga data yang ditemukan lebih sistematis.

\section{Penarikan kesimpulan dan verifikasi}

Pada tahap ini dapat diketahui arti dari data yang telah diperoleh baik melalui observasi, wawancara maupun dokumentasi. Kesimpulan akhir diharapkan dapat diperoleh setelah pengumpulan data selesai.

Langkah-langkah análisis data dapat digambarkan dalam skema berikut. 


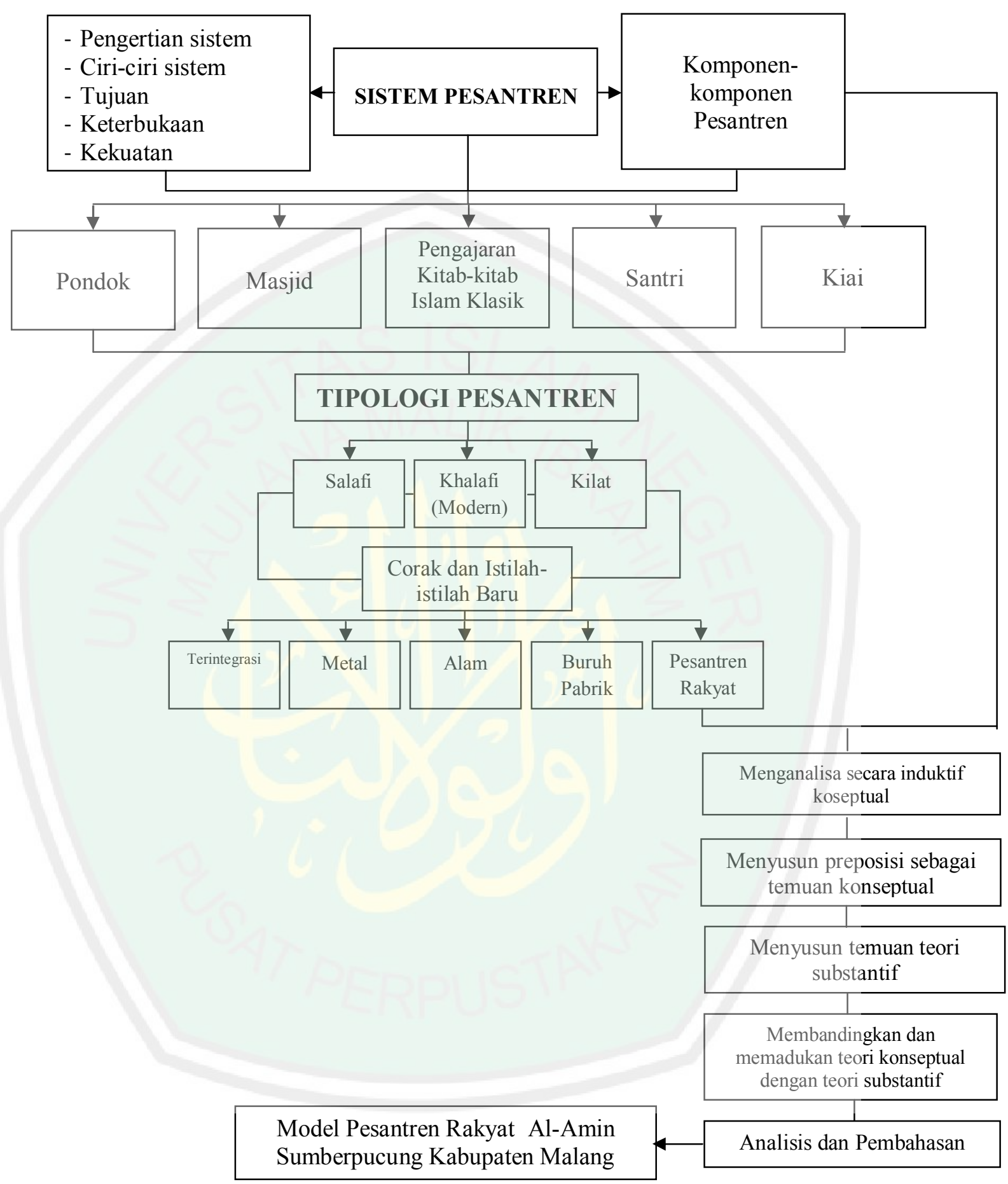

Skema 3.2 Langkah-langkah Analisis Data 
Dari langkah-langkah tersebut dapat dipahami bahwa setelah peneliti menganalisa temuan-temuan penelitian dilanjutkan dengan memadukan atau membandingkan antara hasil penelitian dengan teori, kemudian dari hasil membandingkan dan memadukan tersebut dijadikan dasar menyusun pernyataan konseptual studi kasus. Langkah selanjutnya yaitu mengevaluasi kesesuaian pernyataan (proposisi) tersebut dengan fakta yang diacu. Langkah terakhir merekonstruksi ulang pernyataanpernyataan tersebut sesuai dengan fakta yang ada. Mengulangi proses ini sebagaimana diperlukan oleh peneliti.

\section{G. Pengecekan Keabsahan Temuan}

Pemeriksaan keabsahan data didasarkan pada kriteria-kriteria untuk menjamin kepercayaan data yang diperoleh melalui penelitian. Dalam penelitian kualitatif, keabsahan data merupakan usaha untuk meningkatkan derajat kepercayaan data.

Menurut Moleong terdapat empat kriteria untuk menjaga keabsahan data yaitu kredibilitas atau derajat kepercayaan, kapasitas, dependibilitas atau kebergantungan dan konfirmabilitas atau kepastian. ${ }^{15}$ Sedangkan dalam penelitian ini, peneliti menggunakan tiga kriteria, yaitu kredibilitas atau derajat kepercayaan, dependabilitas atau kebergantungan, dan konfirmabilitas atau kepastian. Kriteria-kriteria tersebut digunakan dalam penelitian sebagaimana dijelaskan sebagai berikut:

\section{Kredibilitas}

${ }^{15}$ Moleong,. Op,. Cit, hlm. 324 
Terdapat beberapa teknik pemeriksaan dalam kriteria kredibilitas, yaitu, perpanjangan keikutsertaan, ketekunan pengamatan, triangulasi, pengecekan teman sejawat, kecukupan referensi, kajian kasus negatif, dan pengecekan anggota. ${ }^{16}$ Agar data yang diperoleh dalam penelitian ini terjamin kepercayaan dan validitasnya, maka pengecekan keabsahan data yang peneliti gunakan adalah metode triangulasi. Triangulasi adalah teknik pemeriksaan keabsahan data yang memanfaatkan sesuatu yang lain di luar data untuk keperluan pengecekan atau sebagai pembanding terhadap data itu. $^{17}$

Denzim sebagaimana dikutip Moleong, membedakan empat macam triangulasi sebagai teknik pemeriksaan yang memanfaatkan penggunaan sumber, metode, penyidik, dan teori. ${ }^{18}$ Adapun teknik triangulasi yang peneliti gunakan dalam penelitian ini adalah sebagai berikut:

a. Triangulasi Sumber

Peneliti melakukan teknik ini dengan cara membandingkan data hasil wawancara dari pihak lembaga dengan data hasil pengamatan, data hasil wawancara dengan dokumen yang berkaitan, serta data hasil pengamatan dengan dokumen yang berkaitan. Hal ini dilakukan untuk menguji validitas data serta mengetahui hubungan antara berbagai data sehingga kesalahan análisis data dapat dihindari.

Peneliti berusaha membandingkan hasil wawancara dari informan yaitu, kiai Pesantren Rakyat Al-Amin, lurah Pesantren

${ }^{16}$ Ibid,.hlm. 327

${ }^{17}$ Ibid., hlm. 330

${ }^{18}$ Ibid,. 
Rakyat Al-Amin, ustadz Pesantren Rakyat Al-Amin, santri Pesantren Rakyat Al-Amin, dan Masyarakat sekitar Pesantren Rakyat Al-Amin.

b. Triangulasi Metode

Peneliti menggunakan teknik ini dengan cara melakukan pengecekan derajat kepercayaan (kredibilitas) beberapa sumber data, yang dalam hal ini adalah informan, dengan metode yang sama. Peneliti mengumpulkan dan membandingkan data yang diperoleh dari satu informan dengan informan lainnya. Misalnya, setelah peneliti melakukan wawancara dengan kiai, lurah, ustadz, santri, dan Masyarakat sekitar Pesantren Rakyat Al-Amin, kemudian hasil wawancara tersebut dikonfirmasikan.

2. Dependabilitas

Kriteria ini digunakan untuk menjaga kehati-hatian akan terjadinya kemungkinan kesalahan dalam menyimpulkan dan menginterpretasikan data, sehingga data dapat dipertanggungjawabkan secara ilmiah. Kemungkinan kesalahan tersebut banyak disebabkan oleh manusia terutama peneliti sebagai instrumen kunci. Oleh karena itu diperlukan auditor terhadap penelitian ini. Dalam penelitian ini, yang bertindak sebagai auditor peneliti adalah Dr. H. Munirul Abidin, M.Ag dan Dr. H. Zulfi Mubarag, M.Ag, selaku pembimbing tesis.

\section{Konfirmabilitas}

Kriteria ini digunakan untuk menilai hasil penelitian yang dilakukan dengan cara mengecek data dan informasi serta interpretasi hasil 
penelitian yang didukung oleh materi yang ada. Metode konfirmabilitas lebih menekankan pada karakteristik data. Upaya ini digunakan untuk mendapatkan kepastian data yang diperoleh dari informan, yaitu kiai Pesantren Rakyat Al-Amin, lurah Pesantren Rakyat Al-Amin, ustadz Pesantren Rakyat Al-Amin. 


\section{BAB IV}

\section{PAPARAN DATA DAN TEMUAN PENELITIAN}

Penelitian ini menyajikan hasil penelitian yang dilakukan di Pesantren Rakyat Sumberpucung Kabupaten Malang yang meliputi, paparan data dan temuan penelitian.

A. Gambaran Umum Pesantren Rakyat Al-Amin Sumberpucung Kabupaten Malang

1. Diskripsi Lokasi Penelitian

a. Sejarah berdirinya Pesantren Rakyat Al-Amin Sumberpucung Kabupaten Malang ${ }^{1}$

Berawal dari melihat kondisi masyarakat yang plural atau heterogen baik agamanya, pekerjaannya, budayanya dan kebiasaannya. dalam pengembangan strategi dakwah Islamiyah anak rakyat yang bernama Abdullaah Sam berfikir bagaimana dakwah akhlak dan aqidah Islamiyah ini bisa menembus kalangan yang paling hitam, terpinggirkan, ekonomi lemah dan pendidikan rendah yang justru sering terlupakan.

Setelah mengalami beberapa uji coba pendekatan dan metode sejak bulan juli 1998, kemudian ada ide pendirian Pesantren Rakyat yang semua aktifitasnya ala rakyat dan disertai dengan nilai-nilai keIslaman, keIndonesiaan dan kemanusiaan.

\footnotetext{
${ }^{1}$ Ghofur. Dokumen Pesantren Rakyat Al-Amin. Lurah Pesantren Rakyat Al-Amin Sumberpucung Kabupaten Malang, 6 April 2013
} 
Pada hari rabu, tanggal 25 juni 2008 berdirilah ide pendirian Pesantren Rakyat. Pesantren Rakayat tumbuh dan berkembang di tengah-tengah lingkungan masyarakat stasiun, pasar, perjudian, togel, perselingkuhan, tempat wisata, penginapan gelap dan di daerah prostitusi terbesar di Kabupaten Malang, dimana masyarakatnya sangat plural atau heterogen. Sehingga mempengaruhi mental dan perilaku keseharian masyarakat dan generasi muda di sekelilingnya.

Dengan kekuatan modal dan kemampuan yang serba minimalis, keluarga kecil Pesantren Rakyat Ingin mengambil bagian dalam proses perubahan sosial ke arah yang lebih baik demi terciptanya masyarakat yang saling memanusiakan manusia dan bertaqwa kepada Allah SWT, demi terwujudnya cita-cita bangsa Indonesia yaitu menjadi negara baldatun thoiyibatun warabbun ghofur atau gemah ripah loh jinawe toto tentrem kerto raharjo.

Langkah tersebut tidak selalu berwujud formal dan berhasil, akan tetapi selalu berusaha sinergi dengan alam, budaya dan lingkungan (bagaikan air yang selalu menyesuaikan dengan tempatnya, bisa menembus lubang-lubang kecil, memberi tekanan ke atas, menguap jika di panaskan, membeku jika didingankan, tawadhu' selalu mencari tempat yang rendah dan jika dibendung secara paksa maka air akan melakukan perlawanan yang hebat).

Pesantren Rakyat mulai dari hal yang kecil, tidak terlihat, sederhana, terpinggirkan/termarjinalkan, tradisional, tidak menarik dan tidak di hiraukan orang, kemudian di kumpulkan menjadi satu 
dan diubah menjadi suatu kekuatan yang dahsyat untuk melakukan proses akselerasi revolusi sosial ke arah yang lebih baik. Untuk itu Pesantren Rakyat dalam rangka menyantrikan rakyat, maka membuat semua kurikulum ala rakyat, mengaji kebutuhan rakyat, perekonomian ala rakyat, pertemuan atau diskusi ala rakyat, pendidikan ala rakyat, menejemen ala rakyat, pakaian ala rakyat, pergaulan ala rakyat dan dalam berbagai aspek bidang kehidupan konsepnya selalu ala rakayat, namun di iringi dengan nilai-nilai Islam yang sesuai dengan ajaran Allah SWT dan Nabi Muhammad SAW serta para ulama' terdahulu, baik dalam tataran syari'at, tharekat, hakikat atau ma'rifatnya.

b. Visi, Misi dan Tujuan²

Setiap program kerja yang diagendakan tentulah berdasarkan pada satu tujuan yang hendak dicapai agar terdapat persamaan persepsi dan mempermudah dalam melaksanakan program tersebut. Sehubungan dengan hal tersebut, maka Pesantren Rakyat Sumberpucung Kabupaten Malang ini juga memiliki visi, misi dan tujuan.

Adapun visi dari Pesantren Rakyat Sumberpucung Kabupaten Malang adalah Terwujudnya lembaga Islam Sosial berhaluan ASWAJA dibidang pendidikan diluar sekolah yang mampu mengantarkan generasi masyarakat sosial yang berguna bagi agama, bangsa dan Negara.

${ }^{2} \mathrm{Ibid}$, . 
Sedangkan misi Pesantren Rakyat Sumberpucung Kabupaten

Malang adalah sebagai berikut:

1. Menyelenggarakan pendidikan Islam di luar sekolah

2. Melakukan kegiatan dakwah dan sosial keagamaan

3. Melakukan advokasi pada anak-anak terlantar, putus sekolah dan masyarakat marginal

4. Membangkitkan semangat sosial masyarakat luas

5. Membagun ekonomi kerakyatan yang mandiri ala santri

6. Meningkatkan profesionalisme dan daya guna kaum santri

Tujuan dari Pesantren Rakyat Sumberpucung Kabupaten

Malang yaitu:

1. Mencetak manusia yang bertaqwa kepada Allah SWT, berakhlakul karimah, memiliki wawasan ke Islaman, mandiri.

2. Berilmu pengetahuan, teknologi, ketrampilan dan memiliki kesadaran sosial yang berguna bagi agama, bangsa dan Negara.

c. Bidang atau Sasaran ${ }^{3}$

Pesantren Rakyat mempunyai bidang atau sasaran untuk mencapai tujuan:

1) Dakwah dan Sosial Keagamaan terdiri dari beberapa hal yaitu (a) mempersiapkan ustadz/ustadzah; (b) kajian keIslaman dan membuka les gratis dengan bayar ngaji; (c) membuka ibadah ritual dan wisata ritual untuk masyarakat (istighosah, tahlil, sholawatan rutin dan ziarah ke Ulama'); (d) sebagai sarana konseling 
kelompok; (e) menyekolahkan dan menguliahkan anak tidak mampu sesuai kemampuan; (f) mendampingi masyarakat marginal dalam menghadapi masalah atau birokrasi; (g) menyiapkan trainer, khotib, penceramah, guru private ngaji dan guru ngaji; (h) bakti sosial di masyarakat; (i) menyantuni yatim/piyatu dan penyaluran permodalan UKM; (j) mendampingi PHBI dan PHBN (fungsi pengembangan diri masyarakat) sebagai sarana konseling sosial; (k) menyediakan sarana dan prasarana intelektual yang cukup (komputer dan buku); (1) dakwah multimedia (internet, buletin dan radio); (m) program sinergi dengan alam/rakyat; (n) membentuk PUSKOMIN rakyat (pusat komunikasi dan informasi rakyat); (o) membentuk forum POSDAYA (pos pemberdayaan keluarga).

2) Pendidikan luar sekolah yaitu (a) kajian keIslaman; (b) diklat ketrampilan dan pengenalan teknologi; (c) diklat kepribadian dan kewirausahaan; (d) pelatihan kepemimpinan dan out bound

3) Advokasi, dalam bidang ini, bentuk kegiatannya berupa: (a) membentuk lembaga swadaya masyarakat bernotaris/legal sebagai alat untuk nahi mungkar (Notaris: Kepanjen-Malang, Lushun Adji Dharmanto, S.H, Akta Tgl 17 November 009, No: 238 LSM ElFaruqi); (b) terhadap anak-anak putus sekolah; (c) terhadap masyarakat marginal, perempuan dan keluarga kasus. 


\section{d. Keberadaan Asatidz}

Jumlah ustadz yang mengajar materi pelajaran di Pesantren Rakyat sebanyak 9 orang: ${ }^{4}$

\section{Nama Asatidz Pesantren}

Rakyat

1. Ust. Abdullah Sam, S.Psi

2. Ust. Syamsul Arifin, cS.Pdi

3. Ust. Wahid Bahruddin

4. Ust. Amin Ma'ruf

5. Ust. Muhammad Anwar

6. Ustzh. Tri Wiyanti, S.Pdi

7. Ustzh. Hidayatul Fitriyah

8. Ust. Drs. Utuh Darsah

9. Ust. Muhid
Pelajaran yang di ampu

KiaiPesantren Rakyat, Aplikatif

Nahwu Shorof, Qiro'ati

Hafalan Surat Pendek, Mabadi'ul Fiqih

Ta'limul Muta'alim, Syi' ir Jawa

Ibu nyaiPesantren Rakyat, Aplikatif

Akhlakunnisa', Risalatul

Mahidh, Qur'an

Qur'an

Tajwid, Syifa'ul Janan

Tabel 4.1 Daftar Nama Ustadz Pesantren Rakyat

e. Sarana dan Prasarana

Untuk menunjang aktivitas warga Pesantren Rakyat dalam menjalankan tugas-tugasnya sehari-hari di pesantren, mutlak diperlukan adanya fasilitas umum. Tersedianya fasilitas umum tentunya diharapkan dapat memperlancar kegiatan yang ada di 
pesantren ini. Adapun sarana dan prasarana yang mendukung, yang diperlukan dan tersedia di Pesantren Rakyat sumberpucung Kabupaten Malang dapat dilihat pada tabel berikut ini. ${ }^{5}$

\begin{tabular}{|c|c|c|c|}
\hline No & Bidang & Sarana dan Prasarana & Keterangan \\
\hline \multirow[t]{8}{*}{1} & \multirow{8}{*}{$\begin{array}{c}\text { Belajar dan } \\
\text { pembelajaran }\end{array}$} & $\begin{array}{l}\text { a. Alat tulis } \\
-\quad \text { White Board }\end{array}$ & $\begin{array}{l}2 \text { buah ukuran } \\
\text { besar dan kecil }\end{array}$ \\
\hline & & - Meja belajar & 15 buah \\
\hline & & - $\quad$ Spidol & Tak terhingga \\
\hline & & b. Tikar & 10 buah \\
\hline & & c. Komputer & 2 buah \\
\hline & & d. Laptop & 3 buah \\
\hline & & e. Modem & 3 buah \\
\hline & & $\begin{array}{l}\text { f. Buku bacaan di } \\
\text { Perpustakaan } \\
\text { - Hard Book } \\
\text { - } \text { Soft Book }\end{array}$ & $\begin{array}{l}700 \text { buku } \\
3000 \text { buku }\end{array}$ \\
\hline \multirow[t]{2}{*}{2} & \multirow[t]{2}{*}{ Jagong Maton } & a. Alat musik gong dll & 1 paket \\
\hline & & b. Alat musik kontemporer & 1 paket \\
\hline 3 & Wirausaha & $\begin{array}{l}\text { Sepeda motor, dan semua } \\
\text { peralatan yang berhubungan } \\
\text { dengan wirausaha yang ada }\end{array}$ & $\begin{array}{l}\text { Tidak } \\
\text { terdeteksi } \\
\text { karena atas hak } \\
\text { milik masing- } \\
\text { masing } \\
\text { pewirausahanya }\end{array}$ \\
\hline
\end{tabular}

Tabel 4.2 Sarana dan Prasarana Pesantren Rakyat

B. Pesantren Rakyat Al-Amin

\section{Model Pesantren Rakyat Al-Amin}

Pesantren Rakyat memiliki beberapa kegiatan pendidikan diantaranya: (1) kegiatan madrasah diniyah rakyat dengan kurikulum ringan; (2) penguatan mental pemuda (from zero to hero); (3) pendampingan di bidang hukum; (4) organisasi dampingan; (5) media

\footnotetext{
${ }^{5}$ Ghofur. Observasi Pesantren Rakyat Al-Amin Sumberpucung Kabupaten Malang. Lurah Pesantren Rakyat Al-Amin Sumberpucung Kabupaten Malang, 10 Pebruari 2013
} 
penyebaran opini (semangat sosial Pesantren Rakyat); (6) pendampingan terhadap keluarga rawan perceraian, perselingkuhan, masalah ekonomi dll; (7) masalah kejiwaan seperti stress, depresi, dan narkoba; (8) Program pendampingan memotivasi anak-anak putus sekolah ${ }^{6}$

Pesantren Rakyat merupakan pesantren yang semua aktifitasnya ala rakyat dengan ditambahi nilai-nilai keIslaman, keindonesiaan dan kemanusiaan. Pesantren Rakyat dalam menyantrikan Rakyat, maka membuat semua kurikulum ala rakyat, mengaji kebutuhan rakyat, perekonomian ala rakyat, pertemuan atau diskusi ala rakyat, pendidikan ala rakyat, menejemen ala rakyat, pakaian ala rakyat, pergaulan ala rakyat dan dalam berbagai aspek bidang kehidupan konsepnya selalu ala rakayat, dan dibarengi dengan nilai-nilai Islam yang sesuai dengan ajaran Allah Swt dan Nabi Muhammad Saw serta para ulama’ terdahulu, baik dalam tataran syari'at, tharekat, hakikat atau ma'rifatnya.

Selain itu, yang menjadi inspirasi pendirian Pesantren Rakyat ada 3 hal, sebagaimana yang disampaikan Bapak Abdullah Sam, S.Psi:

Inspirasi yang nomor satu, Orang abangan di didik, disentuh, disapa, diinspirasi sehingga mereka menjadi percaya diri; kedua, Yai Sholih "Ngalah", orang yang tasawufnya tinggi ibarat air hujan yang selalu mengairi tanah yang gersang maupun tanah yang subur. Dan yang ketiga dari bapak saya sendiri pernah berpesan 3 hal, pertama kalau kepingin jadi orang besar, fikiranmu niruo presiden (siapapun dan seperti apapun rakyatnya, mulai dari orang yang suka mengaji sampai yang ahli korupsi, mulai dari korak sampai qori' tapi oleh Presiden tetap diakui warga Negara Indonesia); kedua menjadikan orang bagaimana bisa makan; ketiga kalau di hina ucapkanlah Alhamdulillah, karena menghina merupakan sebuah sanjungan yang tertinda, dan kalau dipuji jangan bungah (bangga diri). ${ }^{7}$

${ }^{6}$ Op.. Cit.

${ }^{7}$ Abdullah Sam, S.Psi. Wawancara. Kiai Pesantren Rakyat Al-Amin Sumberpucung Kabupaten Malang, 8 Maret 2013 
Dari keterangan di atas bahwa Pesantren Rakyat sangat memperhatikan sesuatu yang mungkin dianggap orang remah, mulai dari yang kecil, tidak terlihat, sederhana,terpinggirkan, termarjinalkan, tidak menarik dan tidak dihiraukan orang, kemudian dikumpulkan menjadi satu, diarahkan untuk melakukan proses akselerasi revolusi sosial ke arah yang lebih baik.

Dalam hal ini Bapak Pailan juga memberikan paparan tentang Pesantren Rakyat:

"Pesantren Rakyat adalah jenis pesantren yang bergabung dengan rakyat (merakyat) dan membangun rakyat dari bawah atau mulai dari nol hingga ke atas"

Hal serupa dikemukakan oleh Saudara Nuril:

"Saya menilai Pesantren Rakyat, khusus saya pribadi, kalo masalah akal jadi gak ntut, maksudnya kok bisa, dengan bangunan yang sederhana tapi mampu mencetak kader-kader yang luar biasa, bisa merangkul semua kalangan baik itu petani, pedagang, pemerintah, pejabat"

Sedangkan gambaran Pesantren Rakyat menurut santri yang pada awalnya mempunyai kebiasaan kurang sesuai (klepto):

"Menemukan segalanya, bisa ngaji, pengalaman organisasi, kebersamaan dan pertama disini bukan karena diri sendiri tapi rekomendasi guru agama, karena saya nakal, tapi d isini saya nyadar bahwa tidak hanya saya saja yang nakal dan saya di sini merasa senang meski pernah dihukum karena melanggar, 10

\footnotetext{
${ }^{8}$ Pailan. Wawancara. Masyarakat Pesantren Rakyat Al-Amin Sumberpucung Kabupaten Malang, 8 Maret 2013

${ }^{9}$ Santri. Wawancara. Santri Pesantren Rakyat Al-Amin Sumberpucung Kabupaten Malang, 6 April 2013

${ }^{10}$ Nuril. Wawancara. Santri Pesantren Rakyat Al-Amin Sumberpucung Kabupaten Malang, 6 April 2013
} 
Hasil wawancara tersebut diperkuat dengan dokumen gambar di

Pesantren Rakyat: ${ }^{11}$
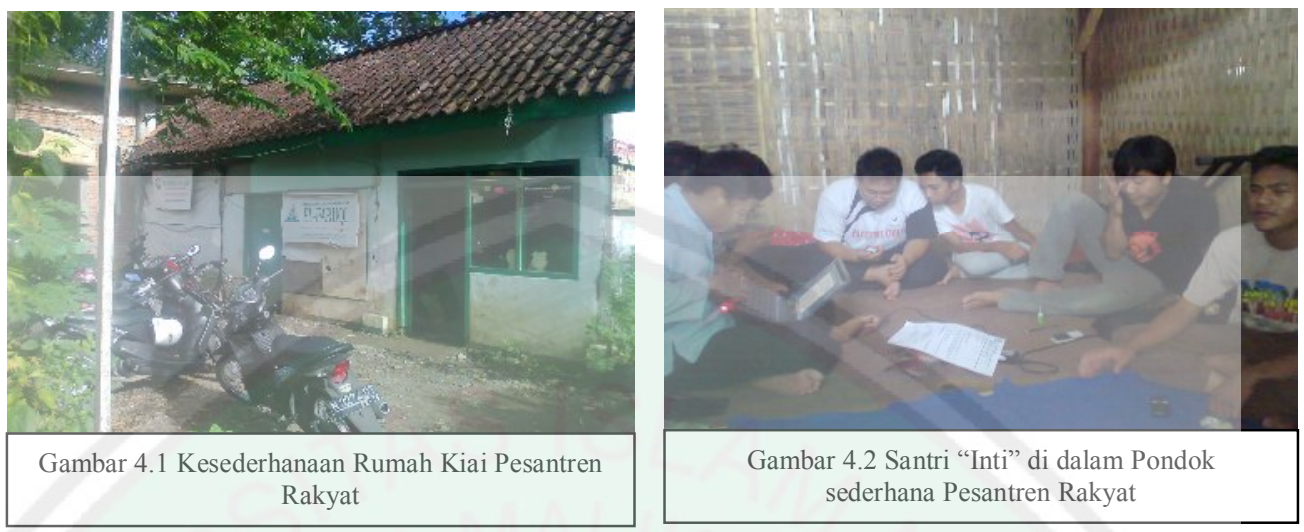

Gambar 4.2 Santri "Inti” di dalam Pondok sederhana Pesantren Rakyat
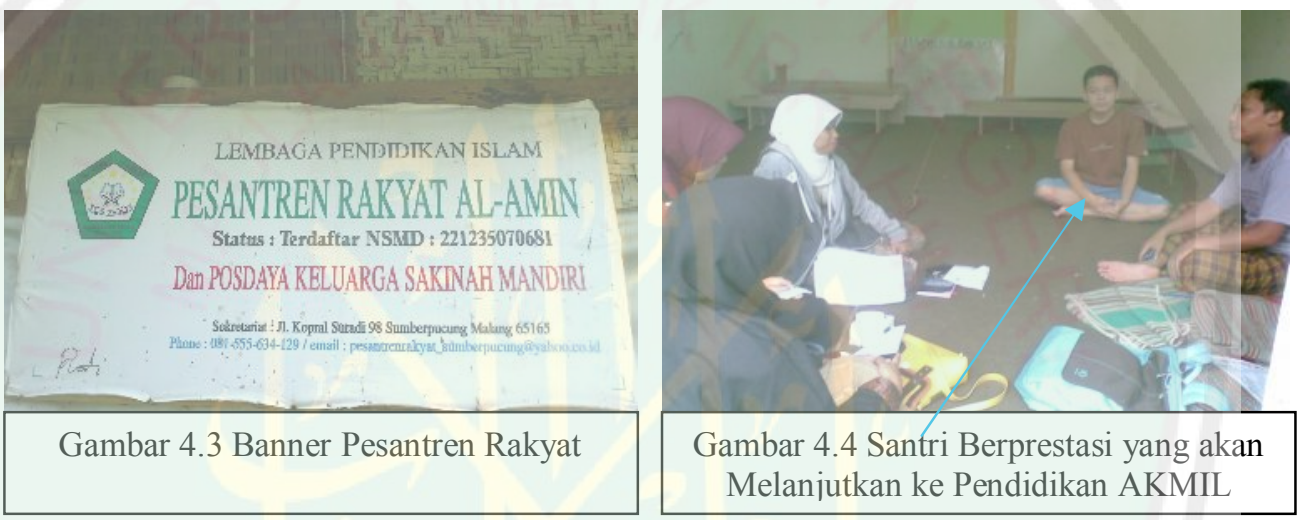

Dilihat dari paparan dan dokumentasi hasil penelitian di atas memberikan gambaran kesederhanaan Pesantren Rakyat, meskipun demikian mampu membentuk santri yang outputnya tidak kalah dari pesantren modern dan tidak perlu membutuhkan biaya sedikitpun, serta dengan usaha keras seorang pemimpin, Pesantren Rakyat mampu mencetak generasi bangsa yang peka dan berkecimpung langsung dengan lingkungan masyarakat, santri mampu berperilaku lokal dan berfikiran global. Pesantren Rakyat tidak pernah mengenal usia santrinya, tidak ada perbedaan kaya atau miskin, di sini adalah tempat yang mampu menampung semua aktifitas dan kemampuan santri, meraka bebas

${ }^{11}$ Dokumen Pesantren Rakyat. 16 Maret 2013 
mengekspresikan minat dan bakat yang mereka punya. Serta didukung dengan adanya seorang pemimpin yang mempunyai keunikan dalam gaya kepemimpinannnya.

Inilah gambaran sistem dan strategi dalam menumbuhkan Pesantren Rakyat, Menciptakan lembaga pendidikan yang komprehensif dengan tanpa memungut biaya sepeserpun dari santri, meski dengan bangunan, gaya hidup yang mencerminkan kesederhanaan tetapi mampu menjadi pesantren percontohan bagi pesantren yang lainnya, dan juga dengan cara mengumpulkan orang-orang hebat untuk menjadikan hebat Pesantren Rakyat.

\section{Komponen Pesantren di Pesantren Rakyat Al-Amin}

a. Pondok

Pengertian secara umum pondok merupakan tempat tinggal para santri. Akan tetapi ada hal baru yang dimiliki oleh Pesantren Rakyat, dimana pondok tidak memiliki bangunan tersendiri dan memanfaatkan sistem terbuka yaitu sistem yang berhubungan dengan lingkungannya, komponen-komponennya dibiarkan mengadakan hubungan keluar dari "batas luar" sistem, di dalam Pesantren Rakyat menggunakan tempat tinggal masyarakat sekitar bagi santri kalong dan bagi santri inti menempati pondok kecil yang sederhana, sedangkan santri pendukung tinggal di rumahnya masing-masing.

Jika disebuah pondok pesantren bangunan "pondok" mempunyai peran dan merupakan komponen yang sangat penting, lain 
halnya di Pesantren Rakyat, pesantren ini tidak memiliki bangunan "pondok" selayaknya pesantren yang lain, tidak adanya "pondok" tidak menjadi pengaruh besar untuk Pesantren Rakyat.

Terkait dengan tidak adanya bangunan pondok sebagai tempat tinggal santri, lebih lanjut disampaikan oleh Bapak Abdullah Sam, S.Psi:

Dari pada membangun tempat tinggal khusus, lebih baik dipakai untuk mengembangkan pengetahuan dan ketrampilan santri, dengan demikian mampu mengembangkan santri dengan langsung bersosialisasi atau berbaur dengan masyarakat. Karena santri yang terdapat di Pesantren Rakyat sangatlah bermacam-macam mulai dari kalangan abangan, rakyat biasa sampai pejabat. Keyakinan iku nomer siji, pesantren rakyat memang tidak mementingkan gedung karena punya mushola, terus setiap masyarakat itu punya kamar, punya ruangan, punya emperan, kelas ala rakyat ${ }^{12}$

Da'i wawancara tersebut dapat diketahui bahwa bangunan pondok sebagai tempat tinggal santri yang berasal dari jauh, dan ingin lebih dekat dengan kiai, kini pondok mengalami sedikit perubahan makna sesuai dengan keadaan Pesantren Rakyat yang mampu memanfaatkan rumah-rumah penduduk sebagai tempat tinggal santri, sehingga pondok disini memiliki makna tempat tinggal santri namun dimanapun tempatnya tidak harus dalam satu bangunan khusus di dalam pesantren, Pesantren Rakyat tidak mementingkan bangunan akan tetapi kekuatan keyakinan yang ditekankan.

${ }^{12}$ Abdullah Sam, S.Psi. Wawancara. Op,.Cit. 6 April 2013 


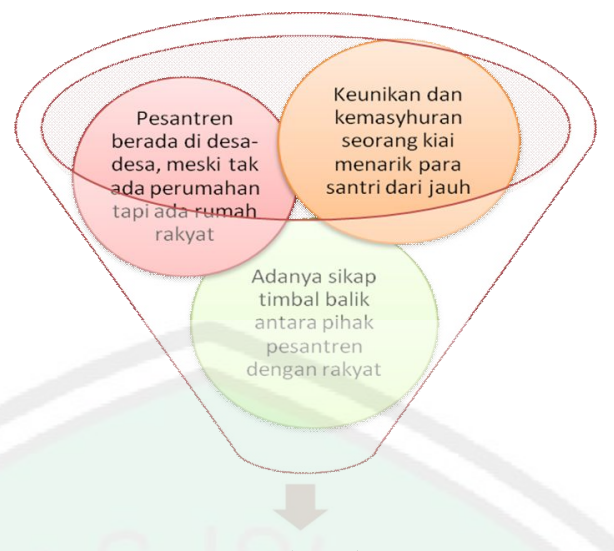

Rumah Rakyat

Skema 4.1 Model "Pondok" di

Pesantren Rakyat Al-Amin

b. Masjid

Masjid tidak hanya berfungsi sebagai tempat ibadah sebagaimana pada umumnya masjid diluar pesantren, melainkan juga berfungsi sebagai tempat untuk mendidik para santri, terutama dalam praktik sholat lima waktu, khutbah dan sholat jum'ah, dan pengajaran kitab-kitab Islam klasik secara umum, hal ini merupakan definisi masjid secara umum. Sedangkan Pesantren Rakyat tidak memiliki bangunan masjid selayaknya Pesantren pada umumnya yang mempunyai masjid di dalam pesantren. Pesantren Rakyat lebih memanfaatkan, meramaikan mushola dan masjid yang ada di lingkungan sekitar Pesantren Rakyat.

Sebagaimana yang dipaparkan Bapak Abdullah Sam, S.Psi kepada peneliti:

"Kita itu berdampingan dengan masjid dan mushola terus lapo kok ngentek-ngentek-i duwek digawe bangun masjid maneh, mending uang itu saya pakai nguliahkan santri itu. Nanti anakanak itu cerdas, beriman, biar masjidnya terisi orang-orang berkualitas. nanti anak-anak santri yang saya kuliahkan itu dari pada saya bangun menara lagi lebih baik santri-santri itu 
meramut masjid-masjid yang sekarang kosong itu. Cukup, lek jawa iki, terutama jawa yang sudah mendekati kota kayak pucung, dan sebagainya gak butuh yang namanya masjid, tambah jamaah iku seng penting, nyatane masjid-masjid iku ya kosong-kosong kok sekarang, terus bagaimana agar kita tidak di hantui akan dihancurkan yahudi, yahudi akan bangga ketika orang itu sibuk membangun masjid sebagai jalan, kemudian rohnya tidak. Artinya kiai ya apik-apikan masjid tidak sholehsholihan santri. Lek pinter-pinteran santri saiki wes umum, "santriku saiki apal Qur'an, fiqih, iku ianatut tholibin, fathul wahab, fathul jare-jarene. Iku wes dadi agung-agungan di masyarakat, tapi sholeh gak di masyarakat?",13

Pernyataan tersebut senada dengan pernyataan Saudara Ghofur mengenai masjid:

Memberdayakan fungsi masjid, mengembangkan fungsi masjid, gimana caranya muadzin itu tetap mendapatkan hasil, tapi mushola tetap ada yang adzan, masyarakat yang mampu itu memberikan sebagian rizqinya untuk masjid, kadang di daerah mushola ada satu lahan tanah bisa dimanfaatkan untuk bibit lele, untuk sayur-sayuran itu bisa. Jadi masjid atau mushola tidak hanya digunakan untuk beribadah dan ngaji saja. $^{14}$

Paparan di atas memberikan pengertian bahwa pendirian masjid di dalam pesantren bagi Pesantren Rakyat bukan merupakan komponen yang sangat penting sehingga setiap pesantren harus mempunyai masjid, karena pada zaman sekarang ini sudah banyak masjid, mushola akan tetapi sering kosong tidak ada penghuninya. Dari pada uang dipakai membangun masjid, lebih baik dipakai menyekolahkan, menguliahkan para santrinya agar bisa menjadi orangorang yang berkualitas sehingga mampu mengurusi, mengisi masjid yang pada saat ini masih sedikit penghuninya.

\footnotetext{
13 Ibid,.

${ }^{14}$ Ghofur. Wawancara. Lurah Pesantren Rakyat Al-Amin Sumberpucung Kabupaten Malang, 10 April 2013
} 
Fungsi masjid di Pesantren Rakyat selain menjadi tempat beribadah dan menjadi tempat belajar, akan tetapi masjid juga difungsikan sebagai tempat berwirausaha, bercocok tanam dan menjadi tempat berbagi dengan sesama yang membutuhkan. Sedangkan tempat untuk belajar dan pembelajaran para santri tidak mempunyai kelas atau ruangan khusus, seperti layaknya pesantren pada umumnya, hal ini sesuai dengan paparan saudara Ghofur:

Pesantren rakyat wajib bersama dengan rakyat atau masyarakat, dan untuk kegiatan dilakukan dimanapun berada, ada yang mengatakan "pesantren tanpa bangku dan pesantren tanpa dinding" kelasnya banyak tidak terbatas hanya disini, misal kelas nyata, di mushola dijadikan sebagai aula, rumah warga sebagai tempat kesenian, femiliarnya dengan sebutan jagong maton. Setiap kami berpijak dan dimanapun itu adalah kelas kita, seperti kolam renang "untuk latihan vokal"15

Santri Pesantren Rakyat, banyak melakukan kegiatan di mushola mulai dari jama'ah, khotmil Qu'ran, dan lain sebagainya. Dan Mereka melakukan kegiatan yang berbasis masjid tanpa harus dengan mendirikan masjid sendiri. Serta di mana kaki berpijak di situlah tempat dan ruang untuk belajar dan mendapatkan ilmu yakni menyatu dengan alam.

Hal inilah yang unik di Pesantren Rakyat, segala kegiatannya merakyat dan bersosialisasi secara langsung dengan masyarakat. Karena pada dasarnya santri pesantren ini adalah semua orang yang mengaku rakyat dan memiliki keinginan untuk belajar. Sehingga setiap orang mampu berpartisipasi dalam kegiatan Pesantren Rakyat yang

${ }^{15} \mathrm{Ibid}$, 
memanfaatkan masjid-masjid dan mushola-mushola yang ada di lingkungan Pesantren Rakyat Al-Amin.

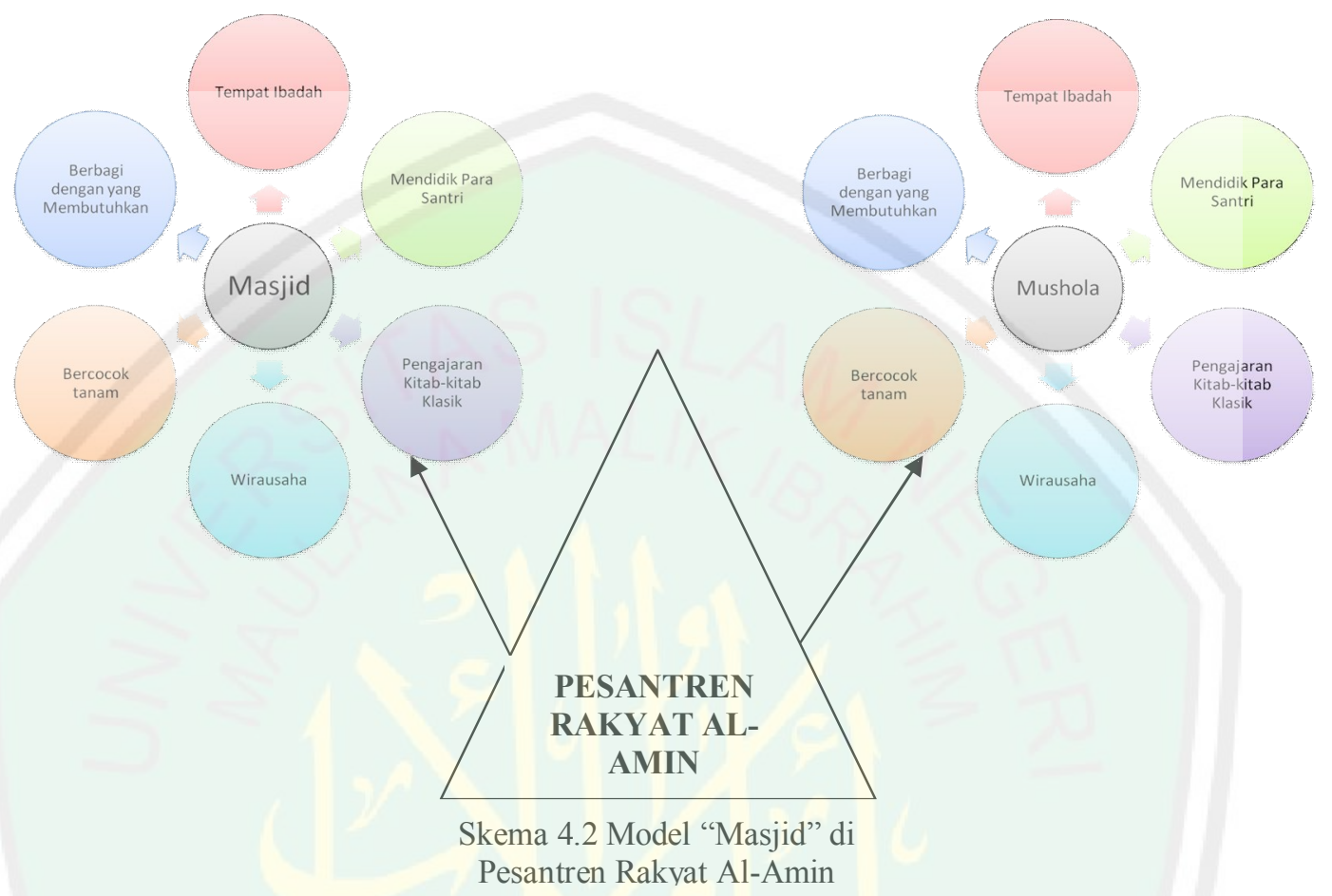

Masjid atau mushola merupakan komponen pesantren yang kedua. Dari gambar di atas menunjukkan bahwa Pesantren Rakyat lebih menekankan pada pemanfaatan dan meramaikan masjid dan musholla di sekitar pesantren, tanpa harus membangun masjid di dalam pesantren seperti halnya pesantren pada umumnya. Fungsi masjid yang pada awalnya sebagai tempat ibadah, mendidik santri dan pengajaran kitab Islam klasik kini di Pesantren Rakyat mampu mengembangkan fungsi masjid, selain masjid mempunyai fungsi dasar tersebut, masjid juga mampu digunakan untuk berwirausaha, bercocok tanam dan berbagi dengan yang membutuhkan. 
c. Pengajaran Kitab-kitab Islam Klasik

Pengajaran kitab-kitab Islam klasik di pesantren sesungguhnya merupakan upaya memelihara dan mentransfer literatur-literatur Islam klasik yang lazim disebut kitab kuning dari generasi ke generasi selama beberapa abad. Oleh sebab itu, pesantren bertugas untuk mencetak manusia yang benar-benar ahli dalam bidang agama dan ilmu pengetahuan kemasyarakatan serta berakhlak mulia. Untuk mencapai tujuan tersebut maka pesantren mengajarkan Tauhid, Fiqh, Tafsir, Hadits, Nahwu, Sharaf, Ma'ani, Badi' dan Bayan, Ushul alFiqh, Musthalah al-hadits, dan Mantiq. ${ }^{16}$

Hal tersebut juga dikemukakan oleh Ust. Abdullah Sam, S.Psi:

Harus menguasai kitab-kitab itu, belum tentu kemudian pondok yang lain harus belajar nahwu shorof tetap ada, cuma standarisasinya mungkin berbeda, yang lain yang konsentrasinya ada kayak pondok saya dulu kan terutama ilmu alat, kiai masduki no.1 nahwu sorofnya, tapi kan ada pondok lain yang penting fiqihnya (fuqoha'nya) yang penting alQur'annya, itu berbeda aja. Namanya fiqih, al Qur'an itu ya basik. Walaupun secara realitas tahapnya tahap proses anakanak ada yang sudah paham ada yang belum kayak mas haris, mas samsul itu ya wes paham kabeh tapi yang pemula-pemula ya jelas belum paham sama saja nanti prosesnya. ${ }^{17}$

Hal tersebut diperkuat oleh lurah saudara Haris:

Ngaji qur'an, kitabnya juga sama,„,cuman ngajinya bebas tapi gak bebas....musimnya anak-anak berkumpul laptop nyala semua. (khataman setiap tahun "syifa'ul jannah, taklimul, nahwu shorof, akhlakunnisa', risalatul mahid" banjari sudah melejit di kabupaten. ${ }^{18}$

\footnotetext{
${ }^{16}$ Ridlwan Nasir., Op,.Cit. hlm. 310-311

${ }^{17}$ Abdullah Sam, S.Psi. Wawancara. Op,.Cit.

${ }^{18}$ Haris. Wawancara. Ustadz Pesantren Rakyat Al-Amin Sumberpucung Kabupaten Malang, 6 April 2013
} 
Dari hasil keterangan tersebut menunjukkan bahwa, pembelajaran kitab-kitab klasik tetap di ajarkan, akan tetapi untuk pembelajaran yang lain bersifat fleksibel dan relevan dengan memperhatikan kesesuaian antara materi yang akan di ajarkan dengan tingkat kemampuan peserta didik dan kebutuhan santri.

Sedangkan bentuk strategi pembelajaran yang ada di Pesantren Rakyat Al-Amin, hal ini sesuai dengan paparan Bapak Abdullah Sam, S.Psi:

Pembelajarannya langsung aplikatif diajak keluar untuk mencari pengalaman, jadi satu kelas itu tidak kita ajar bareng, orang itu kan kebutuhannya beda, kalau di ajar bareng, ekonomi dia jualan minyak semua lak yo gak laku, pijet semua sopo seng dipijeti. $^{19}$

Berdasarkan dari wawancara tersebut Pembelajaran yang dilakukan di Pesantren Rakyat berupa pembelajaran terhadap kehidupan tentang apa yang dibutuhkan oleh Rakyat, pembelajarannya tidak dilakukan di dalam kelas karena santri Pesantren Rakyat memiliki kebutuhan yang berbeda-beda, kecuali untuk santri inti bahwa materi pelajaran dan sistem pembelajarannya tidak dibedakan dengan yang ada di pondok salafiyah.

Sedangkan strategi yang digunakan di Pesantren Rakyat ini adalah melalui pendekatan, menanamkan keyakinan dengan ibroh, qishoh, seni Pesantren Rakyat yang biasa disebut dengan gong-gongan jagong maton serta menggunakan strategi pembelajaran psikologi positif dengan tidak membahas sejarah asal usul santri Pesantren

${ }^{19}$ Abdullah Sam, S.Psi. Wawancara. Op,.Cit. 2 Maret 2013 
Rakyat, tetapi langsung mengembangkan skill positif, ekonomi mampu meningkat dan pembelajaran tetap berlangsung, serta tidak melihat mereka pada satu sisi saja.

Hasil wawancara tersebut diperkuat dengan dokumen gambar pada tanggal 11 Maret 2013, di Pesantren Rakyat Al-Amin:
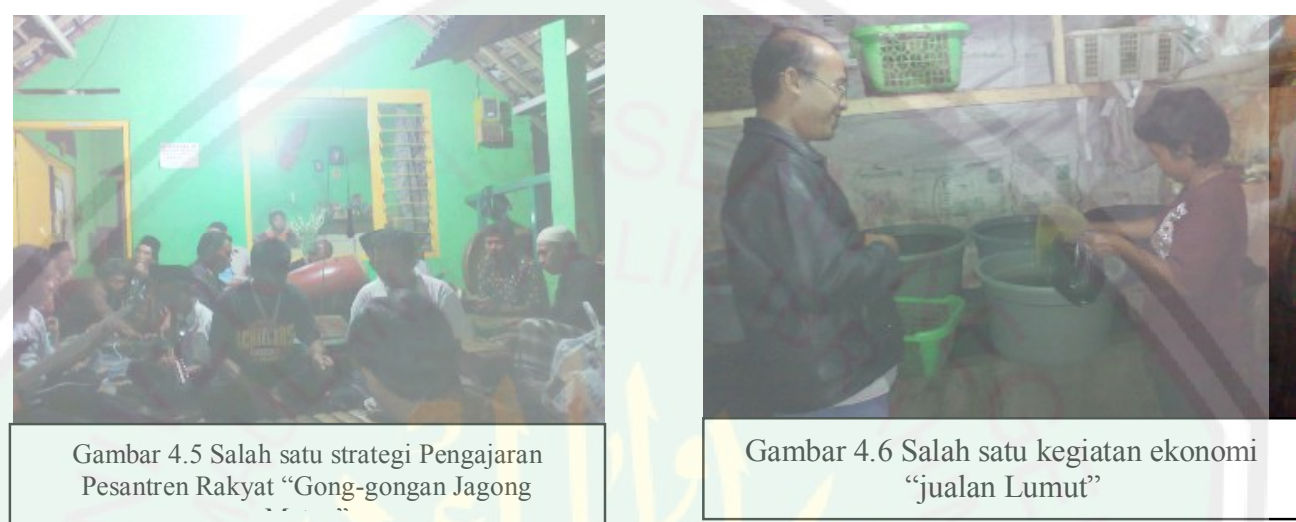

Gambar 4.6 Salah satu kegiatan ekonomi "jualan Lumut"
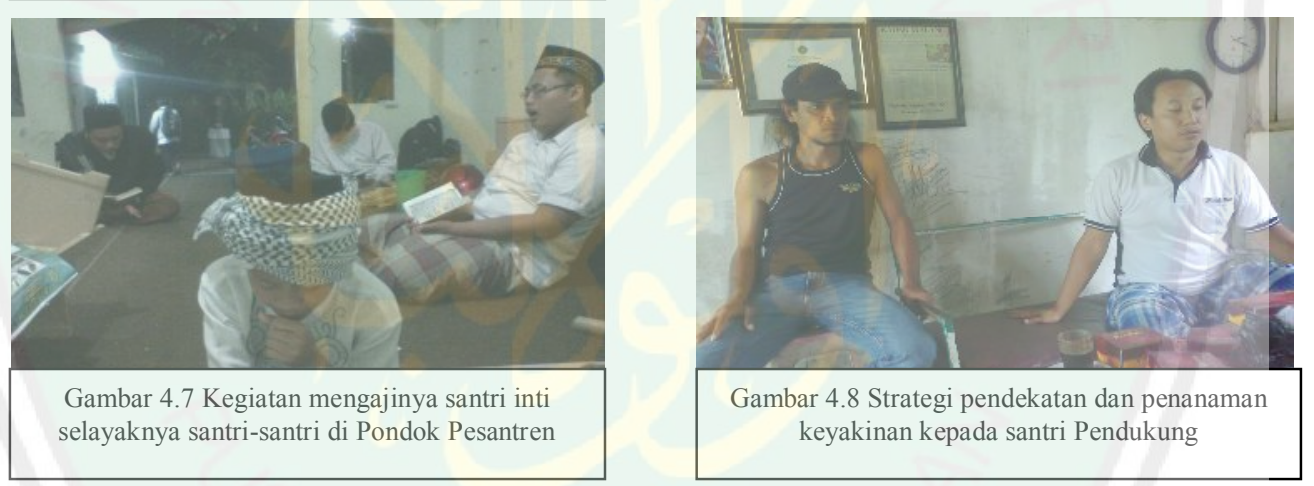

Untuk lebih jelasnya bisa dilihat dalam skema di bawah ini:

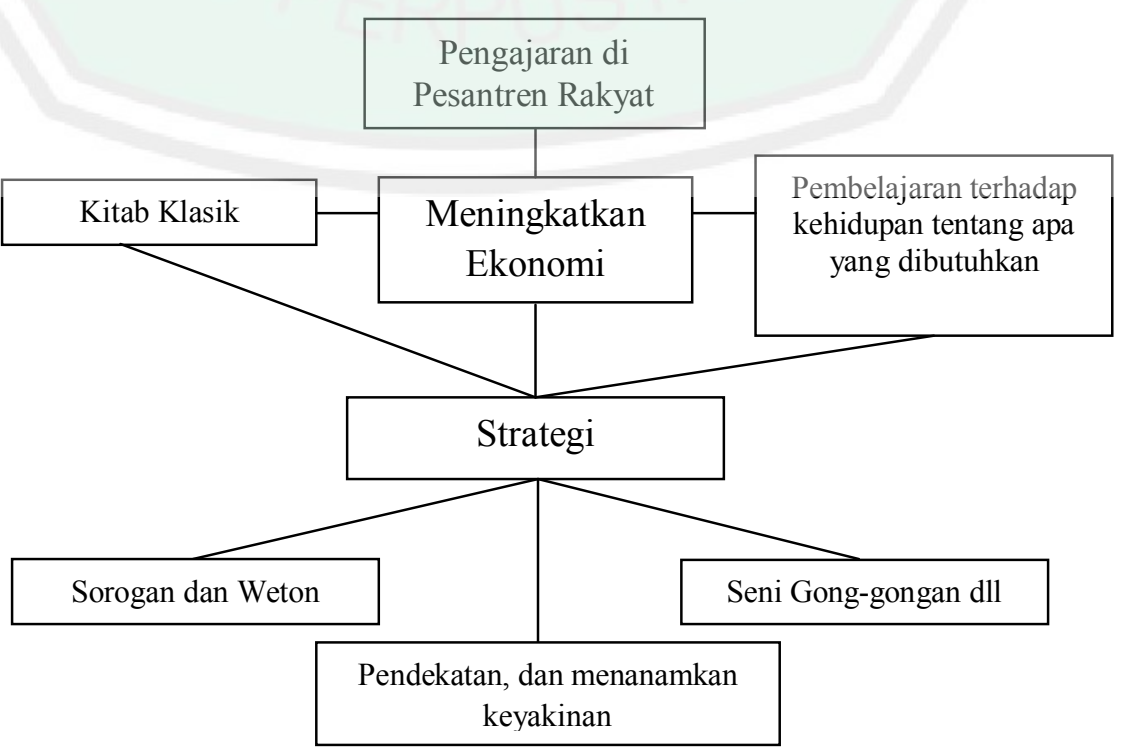

Skema 4.3 Model "Pengajaran Kitab Klasik" di Pesantren Rakyat Al-Amin 
Dan hal ini dapat dibuktikan dengan macam kegiatan yang ada di Pesantren rakyat.

\section{Tabel 4.3}

Macam kegiatan Pesantren Rakyat Al-Amin

(Lihat dilampiran)

d. Santri

Pesantren Rakyat mengenal santri adalah siapa saja yang mengaku rakyat dan mau untuk mengaji, baik mengaji kitab klasik maupun mengaji tentang kehidupan meke a good change to be better (membuat perubahan yang baik untuk menjadi lebih baik). Santri yang belajar di pesantren ini tidak ada batasan usia, mulai dari anak-anak sampai lansia, selama orang tersebut mau belajar maka dinamakan santri.

Sebagaimana yang dipaparkan oleh saudara Ghofur: semua yang mengaku rakyat adalah santrinya Pesantren Rakyat, tidak terbatas umur,,bahkan presiden pun jika mengaku rakyat juga merupakan santri di Pesantren Rakyat. ${ }^{20}$

Dari paparan tersebut dapat di ambil kesimpulan bahwa santri adalah semua kalangan yang mengaku sebagai rakyat dan tidak pandang usia, sehingga untuk menjadi santri di Pesantren Rakyat tanpa adanya seleksi masuk selayaknya pesantren lainnya. Dalam hal ini Pesantren Rakyat mengenal tiga kelompok santri, yaitu: santri inti, santri kalong dan santri pendukung. Pertama santri inti merupakan santri yang belajar kitab layaknya santri di pesantren salafiyah.

Hal ini sesui dengan paparan Bapak Abdullah Sam, S.Psi:

${ }^{20}$ Ghofur. Wawancara. Op..Cit. 2 Maret 2013 
Untuk santri inti pembelajarannya untuk ilmu agama itu tidak berbeda dengan pondok salaf pada umumnya, Misalkan tadi ya ada fiqih, ada akidah, ada akhlak yaitu taklimul muta'alim ada al-Qur'an, ya ada ilmu alat Nahwu shorof juga kita ajarkan, hadits wasiyatul musthofa, akhlakul banin, adabul mar'ah, sulam safinah, risalatul mahid dengan pondok-pondok salaf tidak beda, cuman bedanya anak-anak disini itu saya katakan sangat bebas mengekspresikan minat bakatnya itu, memang dia langsung bersentuhan dengan masyarakat, yang sekolah ya sekolah, yang ngaji ya ngaji, yang dodol ya dodol seng cangkru' yow cangkru'o, lok kamu seneng gitar yo golekono wong seng seneng gitar, seng pengen terbang yo keluaro, tak tunjukno iki seng ahli gitar, iki seng ahli terbang, karena saya yakin kalau ustadz yang di pondok Cuma 10 orang itu hanya 10 kreatifitas yang akan keluar, tapi dengan bersentuhan dengan masyarakat. Pembelajaran ini tidak hanya pada satu bagian, dan laki-laki perempuan tidak saya skat-skat, karena buat saya benteng itu bukan tembok, bentengnya anak muda, bentengnya laki-laki perempuan itu bukan tembok, jebol itu. Tapi mental dan fikirannya dan hatinya yang kita kuatkan bahwa suatu kemaksiyatan yang kamu lakukan itu akan berakibat. ${ }^{21}$

kedua santri kalong adalah santri yang pulang pergi dari rumah, datang ke pesantren hanya pada waktu mengaji. ${ }^{22}$

Ketiga santri pendukung, santri yang terdiri dari semua orang yang mengaku rakyat, mulai dari kalangan alit sampai kalang elit.

Bidikan Pesantren Rakyat adalah masyarakat, hal ini sesuai dengan paparan Bapak Abdullah Sam, S.Psi:

Pesantren Rakyat, Untuk yang saya bidik itu ya yang dari masyarakat itu, model pembelajarannya ketemu di warung kopi, ketemu akhirnya beliau pembelajarannya dipeningkatan indomini, misal sudah sregep tapi menejerialnya kurang, skillnya tidak pernah tersalurkan. Maka dikuatkan, menggunakan psikologi positif, jika ada sebuah masalah maka masalah itu tidak dibicarakan, misalnya ada persoalan atau sejarah, sejarah itu akan menjadi pengganggu jika dimunculkan, ah sejarah ini tidak dimunculkan namun potensi ini yang dimunculkan dan pembelajarannya langsung aplikatif

${ }^{21}$ Abdullah Sam, S.Psi. Wawancara. Op,.Cit. 2 Maret 2013

${ }^{22}$ Ghofur. Wawancara. Op,.Cit. 6 April 2013 
diajak keluar untuk mencari pengalaman, jadi satu kelas itu tidak kita ajar bareng, orang itu kan kebutuhannya beda ${ }^{23}$

Dari paparan di atas menunjukkan bahwa santri Pesantren Rakyat merupakan semua santri yang mengaku rakyat "kita yang belajar, kita yang mengajar dan kita yang memberi gelar" merupakan ciri khusus di Pesantren Rakyat, dalam hal ini santri Pesantren Rakyat bebas belajar dimana saja sesuai kemampuan yang mereka bidangi. Tidak terpaku pada Pesantren Rakyat saja.

Hal tersebut digambarkan dalam sebuah skema di bawah ini:

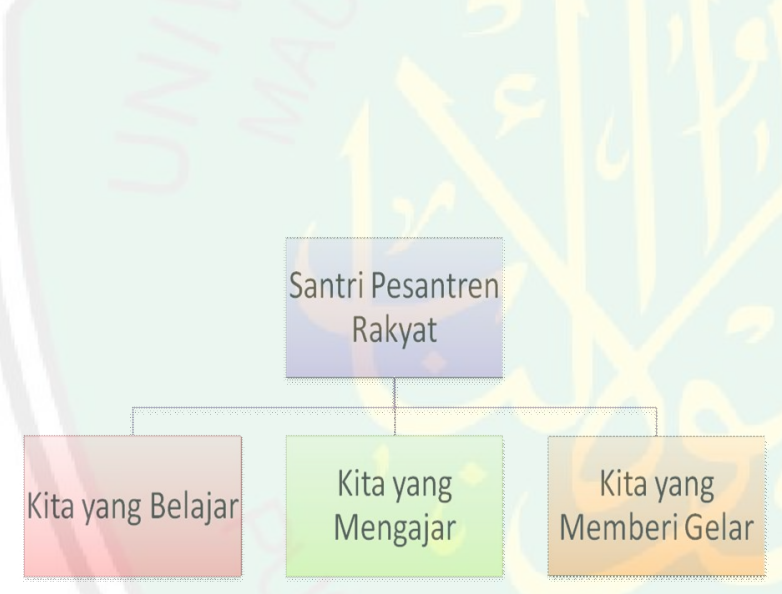

Skema 4.4 Makna Santri Pesantren Rakyat Al-Amin

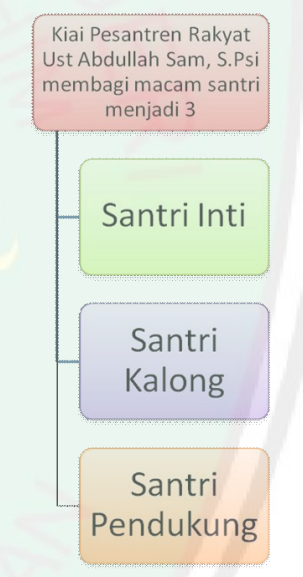

Skema 4.5 Macam-macam santri

e. Kiai

Dari beberapa kasus di pesantren, kiai bukan hanya sebagai pendiri pesantren, tetapi sekaligus juga sebagai pemilik pesantren. Karena itu, kiranya logis jika dikatakan bahwa perkembangan pesantren sangat tergantung kepada para kiai selaku pendiri dan pemilik pesantren. ${ }^{24}$ Jika dikatakan bahwa keberadaan seorang kiai

${ }^{23} \mathrm{Ibid}$,

${ }^{24}$ Azyumardi Azra. Op..Cit, hlm. 149 
dalam lingkungan sebuah pesantren laksana jantung bagi kehidupan manusia. Intensitas kiai memperlihatkan peran yang otoriter disebabkan karena kiailah perintis, pendiri, pengelola, pengasuh, pemimpin, dan bahkan juga pemilik tunggal sebuah pesantren. Oleh sebab alasan ketokohan kiai di atas, banyak pesantren akhirnya bubar lantaran ditinggal wafat kiainya. Sementara kiai tidak memiliki keturunan yang dapat melanjutkan usahanya. ${ }^{25}$

Lain halnya dengan kiai di Pesantren Rakyat yang bersifat demokratis dan tidak pernah memperlihatkan ke-kiai-annya, bersifat luwes dan selalu terbuka dengan siapapun. Dalam paparan beliau, bahwa Pesantren Rakyat ini adalah milik rakyat, dari rakyat, oleh rakyat, dan untuk rakyat.

Hal tersebut diperkuat oleh Ghofur dalam wawancara dengan peneliti:

"Rencana terbentuknya kegiatan terjadi secara spontanitas, jadi tidak kaku dan tidak terpaku pada satu pemikiran, semua berhak menemukan apa yang akan dijadikan kegiatan, kiai sangat demokrasi, setelah teman-teman punya pemikiran maka di aturkan ke kiai untuk diketok palu. ${ }^{26}$

Dari paparan di atas menunjukkan bahwa di Pesantren Rakyat tidak hanya kiai yang menentukan segala sesuatunya, namun semua berhak ikut andil dan kiai di sini lebih bersifat lentur dan fleksibel. Sedangkan menurut pendiri Pesantren Rakyat makna kiai adalah orang yang berilmu. Tidak sembarang orang disebut kiai, misalkan orang yang memiliki satu kelebihan belum bisa disebut kiai. Sebagai

${ }^{25}$ Imam Bawani, Op,. Cit, hlm. 90

${ }^{26}$ Ghofur. Wawancara. Op..Cit. 6 April 2013 
contohnya ahli fiqih disebut fuqoha', ahli qiro'ah disebut qori', hafal al-Qur'an disebut hafidz/hafidzoh. Dan beliau lebih suka sebutan kiai itu dinamakan Ulama' tapi bukan makna secara hakiki yaitu sebatas orang yang berilmu.

Zaman sekarang ini, banyak orang yang menjadi kiai dan kemampuan yang dimilikinya juga berbeda-beda. Yang jelas, tidak ada kiai yang memiliki kemampuan sempurna selayaknya ulama besar karena setiap pesantren memiliki tipe yang berbeda-beda. hal ini menunjukkan bahwa kiai sangat besar pengaruhnya terhadap kualitas santri. Di dalam Pesantren Rakyat, kiai tidak banyak memberikan teori namun contoh secara langsung dan menjadi figur bagi masyarakat umum (strategi aplikatif). ${ }^{27}$

Hal ini sesuai dengan pernyataan saudara Ghofur:

Beliau bisa menjadi kakak, bisa menjadi teman, bisa menjadi sahabat, bisa menjadi guru atau bahkan bisa menjadi mbah saya, beliau tidak mau dipanggil kiai, pernah bilang ke aku "aku gak seneng sampeyan panggil yai, panggil ca' ae seneng" seperti itu, sosok kepemimpinannya selalu bisa membuat orang sekitarnya itu seneng, bukan seneng hura-hura tapi bisa membuat orang tertawa semacam kayak ada yang mengayomi. $^{28}$

Sebagaimana yang dipaparkan juga oleh saudara Haris:

"Keunikan yai, sehingga saya juga termotivasi untuk mendirikan pesantren seperti ini di daerah saya "lamongan" metode dan caranya unik, dan juga yang saya rasakan belajar dari pak Abdullah, untuk menggandeng semua kalangan dari korak sampai qori'. Metode: ala pesantren salaf tapi dibantu dengan kemodernan, tetap untuk tradisi pesantren salaf, tapi pemikiran modern, wajah boleh preman tapi hati tetep ka'bah",29

\footnotetext{
${ }^{27}$ Abdullah Sam, S.Psi. Wawancara. Op,.Cit., 3 Maret 2013

${ }^{28}$ Ghofur. Wawancara. Op..Cit. 17 April 2013

${ }^{29}$ Haris. Wawancara. Op..Cit. 17 April 2013
} 
Hal tersebut diperkuat oleh Nuril ketika di wawancarai peneliti:

Pesantren sederhana tapi luar biasa, dan memiliki Pengasuh (Ust. Abdullah) panggilan akrabnya cak Dolah yang sangat sederhana, namun mampu merangkul semua kalangan. Bahkan santri-santrinya mampu bersaing dengan pesantren di sumberpucung, segudang prestasi-pun mampu di sabet oleh Pesantren Rakyat"30

Paparan di atas sesuai dengan dokumen pengambilan gambar kiai Pesantren Rakyat yang sangat sederhana dan unik, terlihat dari ekspresi dan cara berkomunikasi dengan semua kalangan.
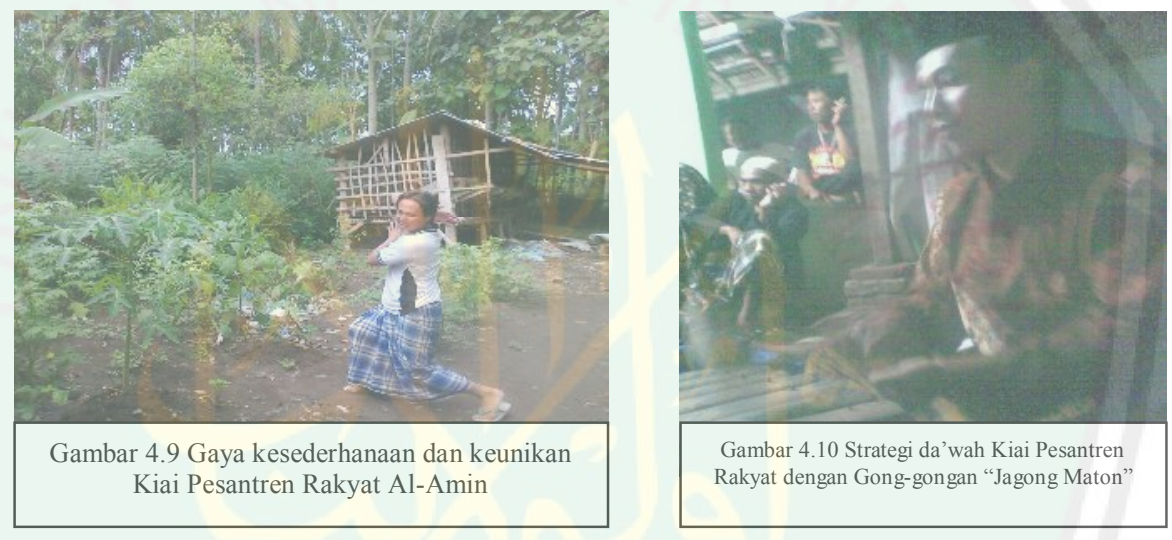

Dari paparan tersebut menggambarkan bahwa kiai di Pesantren

Rakyat tidak mempunyai kebijakan namun kebijaksanaan, dengan strategi aplikatif dan multi strategi, beliau menjadi figur sentral bagi para santri di Pesantren Rakyat. Hal ini menunjukkan bahwa peran kiai memang sangat besar didalam lingkungan pondok, hanya saja setiap pondok memiliki tipe kiai yang berbeda-beda.

Jadi yang disebut ulama menurut pendiri pesantren rakyat ini adalah orang yang ahli dalam fiqih, ahli qiro'ah lebih baik lagi ketika mampu menjadi penghafal al-Qur'an. Selain itu, ulama itu juga

${ }^{30}$ Nuril. Wawancara. Op..Cit. 6 April 2013 
mampu dalam bidang politik, kesenian, bisa berkomunikasi dengan rakyat kecil, bisa berkomunikasi dengan pejabat yang paling tinggi, berbaur sama orang yang bejat, bisa bercampur dan bersosialisasi dengan orang mlarat (miskin), sehingga di pondok ini kiai tidak hanya mengajarkan fiqih saja tetapi juga menjalankan ma'rifat.

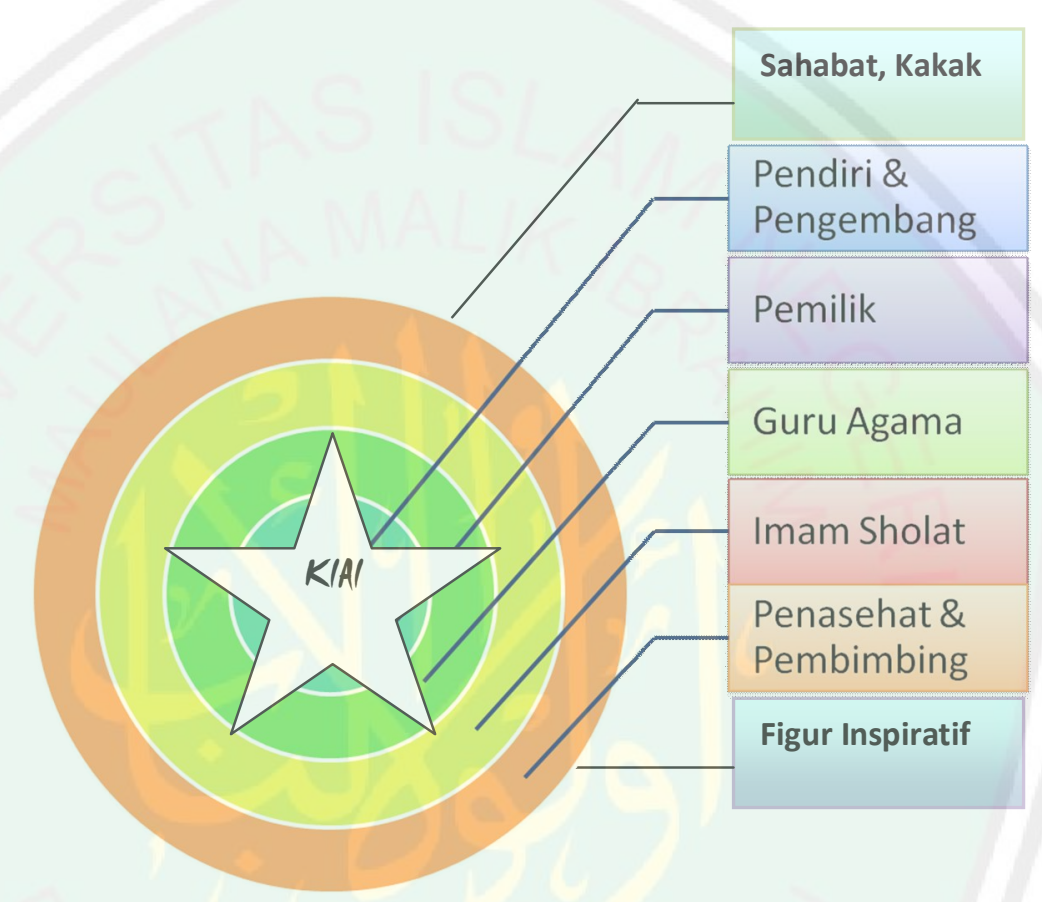

Skema 4.6 Peran Kiai di Pesantren Rakyat Al-Amin 


\section{BAB V}

\section{DISKUSI HASIL PENELITIAN}

\section{Model Pesantren Rakyat Al-Amin Sumberpucung Kabupaten Malang}

Pesantren merupakan lembaga pendidikan Islam tertua di Indonesia, pesantren merupakan tempat yang memberikan pendidikan dan pengajaran serta mengembangkan dan menyebarkan luaskan ilmu agama Islam, sedangkan orang yang belajar di pesantren disebut dengan santri, baik yang bertempat tinggal di dalam pesantren maupun yang pulang pergi dari rumahnya masing-masing, dalam hal ini biasa di sebut dengan santri kalong. Jika dibandingkan dengan pesantren pada umumnya, bahwa pengembangan sistem pendidikan Pesantren Rakyat dengan pesantren salafiyah atau modern, terdapat perbedaan dan mengalami perkembangan, mulai dari nama /corak pesantren, komponen pesantren dan juga dari strategi kepemimpinan seorang kiai, Pesantren Rakyat merupakan pesantren yang semua kegiatan/aktivitas dan kurikulum ala rakyat, yang mana santrinya adalah semua rakyat, tidak ada batasan usia, tidak puls pandang bulu, mulai dari kalangan korak hingga qori', kalangan alit maupun elit, semua sama tidak ada bedanya.

Kekuatan kolaborasi ini terletak pada Pertama modal sosial yang dikembangkan melalui pendampingan secara istiqomah berorientasi pada pemberdayaan dan peningkatan serta pemerataan kesejahteraan; kedua medan budaya yang bernuansa tradisi lokal, kental dengan simbol-simbol kerakyatan sehingga menimbulkan rasa nyaman khususnya bagi santri pendukung; ketiga pendekatan adaptatif, multi strategic, luwes dan berbasis kearifan lokal; keempat 
aktor pemimpinnya memiliki kredibelitas, integritas, komitmen kuat, istiqomah dalam berjuang serta mampu menjadi tokoh inspiratif bagi santrinya; dan kelima dukungan jejaring stakeholders menjadi yang akrab dan memiliki dedikasi yang tinggi dalam mengembangkan lembaga. ${ }^{1}$

Komponen pesantren menurut teori yang ada seperti yang di skemakan di bawah ini: ${ }^{2}$

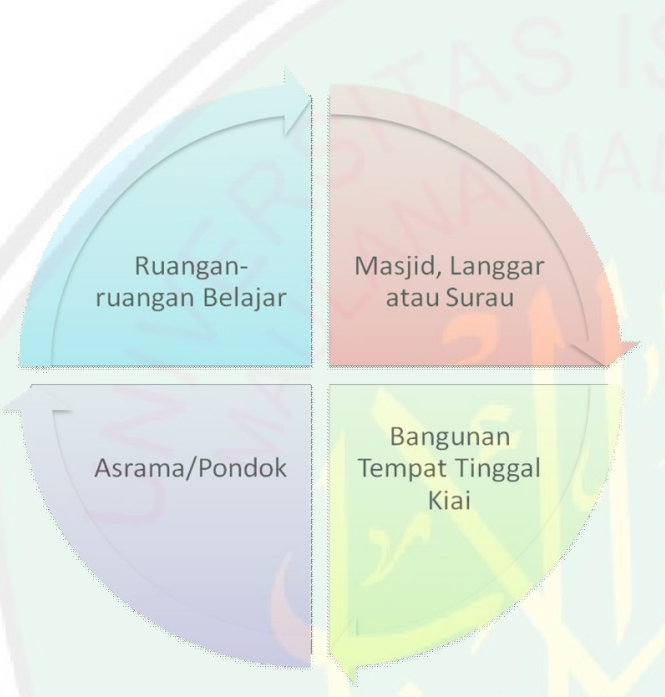

Skema 5.1 Empat komponen Pesantren menurut Manfred Ziemek

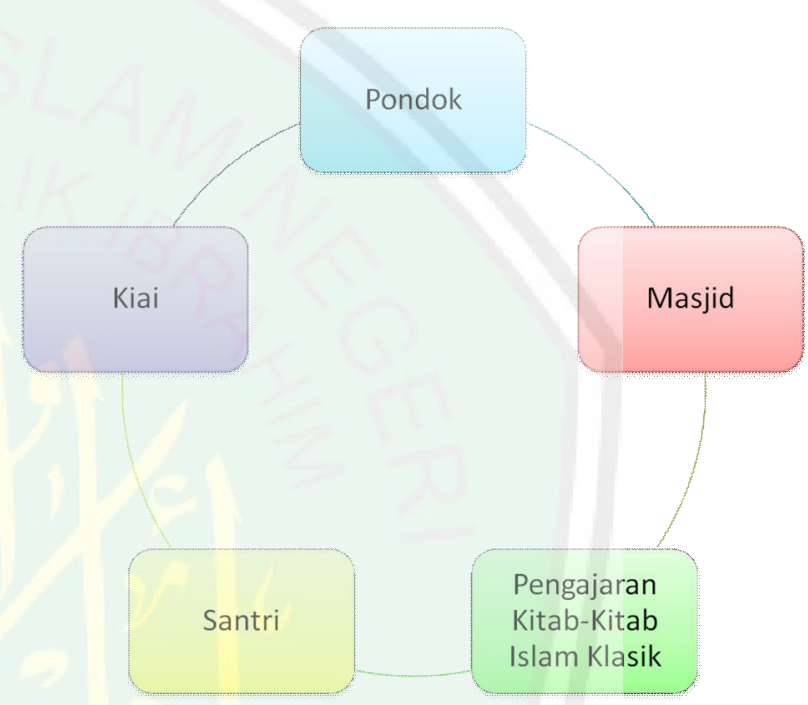

Skema 5.2 Lima Komponen Pesantren menurut Zamakhsyari Dhofier

Hasil penelitian di Pesantren Rakyat Sumberpucung Kabupaten Malang justru mempunyai komponen yang berbeda dengan teori yang telah ditetapkan, di Pesantren Rakyat komponen-komponen tersebut tidak selamanya mempunyai pengaruh penting bagi pesantren, Pesantren Rakyat, pesantrennya rakyat, semua aktifitas ala rakyat, dan mempunyai kurikulum ala rakyat, pesantren ini hanya memenuhi 3 komponen pesantren, yaitu kiai, pengajaran kitab klasik dan santri. Selebihnya merupakan medan budaya yang di Islamkan tanpa mengurangi nuansa lokal yang masih mereka pertahankan, meskipun di pesantren ini pada hakikatnya

\footnotetext{
${ }^{1}$ Mufidah. Ch,.Op,. Cit. hlm. 131

${ }^{2}$ Manfred Ziemek. Op,.Cit. hlm. 101 dan Zamakhsyari Dhofier. Op,.Cit. hlm. 159
} 
semua komponen tersebut tatap ada, namun ada pengembangan konsep dan fungsi, yang lebih jelasnya akan di paparkan peneliti satu persatu sesuai denga komponen pesantren yang ada.

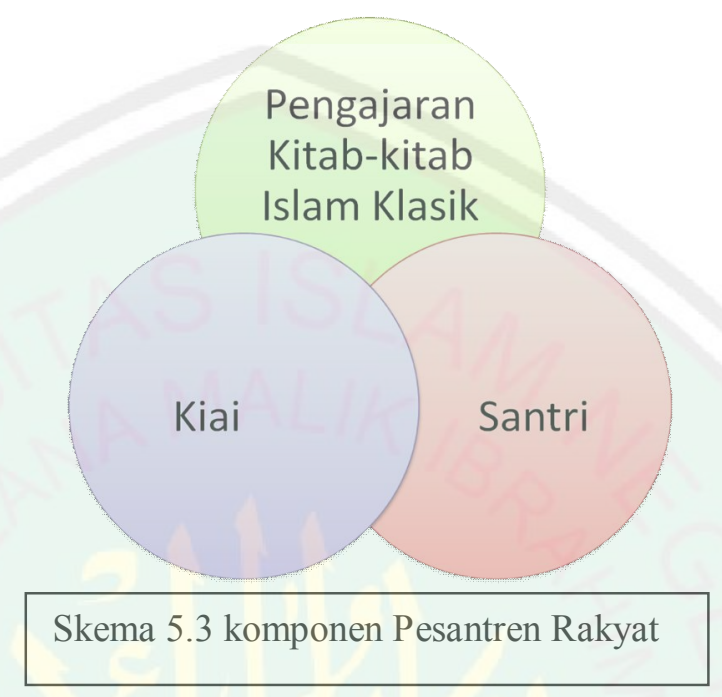

1. Pondok

Pondok merupakan asrama bagi santri yang menjadi ciri khas tradisi pesantren, yang membedakannya dengan sistem pendidikan Islam tradisional lainnya - seperti masjid, surau, dan atau langgar.

Menurut Zamakhsyari Dhofier, ada tiga alasan yang mendasari pesantren harus menyediakan asrama bagi para santrinya:

a. Kemasyhuran seorang kiai dan kedalaman pengetahuannya tentang Islam menarik para santri dari jauh, dan ini berarti memerlukan asrama;

b. Hampir semua pesantren berada di desa-desa dimana tidak tersedia perumahan (akomodasi) yang cukup untuk dapat menampung para santri, sehingga memerlukan asrama; dan 
c. Adanya sikap timbal balik antara kiai dan santri, dimana para santri menganggap kiainya seolah-olah sebagai bapaknya sendiri, sedangkan kiai menganggap para santri sebagai titipan Tuhan yang harus senantiasa dilindungi. ${ }^{3}$

Teori tersebut menunjukkan bahwa pondok merupakan komponen pesantren yang sangat penting, namun demikian dari hasil penelitian ini ada perbedaan dan pengembangan sistem yang ada, yakni seperti yang tergambarkan dalam skema di bawah ini.

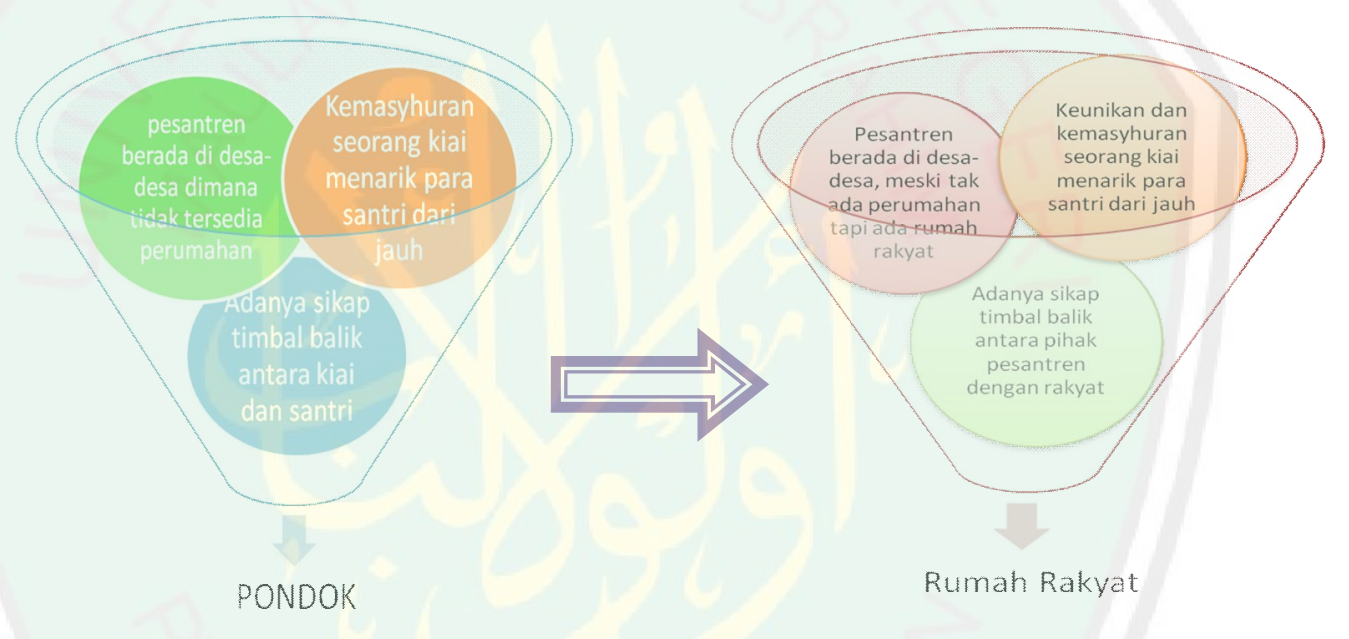

Skema 5.4 Model "Pondok" di Pesantren Rakyat Al-Amin

Berdasarkan skema di atas terlihat adanya sebuah perbedaan dan pengembangan sistem dalam komponen pesantren, jika pesantren pada umumnya "pondok" merupakan komponen yang sangat penting, adanya sebuah pondok selain menjadi tempat tinggal santri juga agar tercipta sikap timbal balik antara kiai dan santri, selain itu pesantren sering kali berada di pedesaan yang jauh dari perkotaan dimana tidak tersedia perumahan untuk menampung atau sebagai tempat tinggal para santri.

${ }^{3}$ Zamakhsyari Dhofier, Op,. Cit, hlm. 47 
Lain halnya dengan Pesantren Rakyat, Pesantren Rakyat tidak mempunyai bangunan pondok selayaknya pesantren pada umumnya, tidak adanya komponen pesantren "pondok" bukan berarti komponen ini tidak mempunyai arti penting di Pesantren Rakyat, hanya saja fungsi dan sistem pondok di sini yang berbeda, jika di pesantren pada umumnya ada sebuah bangunan pondok sebagai tempat tinggal santri, di Pesantren Rakyat, rumah rakyatlah yang menjadi tempat tinggal para santri, semua kegiatan ala rakyat dan santri wajib membaur dengan rakyat. Inilah yang menjadi alasan mengapa di pesantren ini tidak ada bangunan pondok selayaknya pesantren pada umunya.

\section{Masjid}

Berkenaan dengan kedudukan masjid, Dhofier menulis:

"Kedudukan masjid sebagai pusat pendidikan Islam dalam tradisi pesantren merupakan manifestasi universalisme dari sistem pendidikan Islam tradisional. Dengan kata lain, kesinambungan sistem pendidikan Islam yang berpusat pada masjid sejak masjid al-Quba' didirikan didekat madinah pada masa Nabi Muhammad Saw tetap terpancar dalam sistem pesantren. Sejak zaman Nabi, masjid telah menjadi pusat pendidikan Islam. Dimanapun kaum muslimin berada, mereka selalu menggunakan masjid sebagai tempat pertemuan, pusat pendidikan, aktivitas administrasi dan kultural. Hal ini telah berlangsung selama 13 abad. Bahkan dalam zaman sekarang pun di daerah di mana umat Islam belum begitu terpengaruh oleh kehidupan barat, kita temukan para ulama yang dengan penuh pengabdian mengajar siswa-siswa di masjid, serta memberi wejangan dan anjuran kepada siswa-siswa tersebut untuk meneruskan tradisi yang terbentuk sejak zaman permulaan Islam itu"4

Jika melihat paparan di atas bahwa masjid tidak hanya digunakan sebagai tempat ibadah sebagaimana pada umumnya masjid diluar pesantren, melainkan juga berfungsi sebagai tempat untuk mendidik para

${ }^{4}$ Ibid,. Tradisi Pesantren. Op,.Cit, hlm. 49 
santri, terutama dalam praktik sholat lima waktu, khutbah dan sholat jum'ah, dan pengajaran kitab-kitab Islam klasik. Karena itu, masjid merupakan komponen yang tidak dapat dipisahkan dari pesantren. Secara historis, pesantren merupakan transformasi dari lembaga pendidikan Islam tradisional yang berpusat di masjid, masjid telah menjadi pusat pendidikan Islam. Dimanapun kaum muslimin berada, mereka selalu menggunakan masjid sebagai tempat pertemuan, pusat pendidikan, aktivitas administrasi dan kultural, namun hal tersebut mengalami sedikit pergeseran, masjid yang ada di dalam pesantren tak jarang jika hanya digunakan sebagai tempat beribadah dan pendidikan Islam. Padahal jika melihat fungsi masjid yang begitu luasnya, sangat disayangkan jika masjid harus kehilangan fungsi yang lain.

Meski masjid merupakan komponan yang tidak bisa dipisahkan dengan pesantren, namun Pesantren Rakyat tidak memiliki bangunan masjid di dalam pesantren, pesantren ini lebih mementingkan untuk memanfaatkan dan meramaikan masjid dan mushola di sekitar lingkungan pesantren tanpa harus menghilangkan fungsi masjid sedikitpun, justru melestarikan dan mengembangkan fungsi masjid. Hal ini bisa dilihat dari skema di bawah ini. 


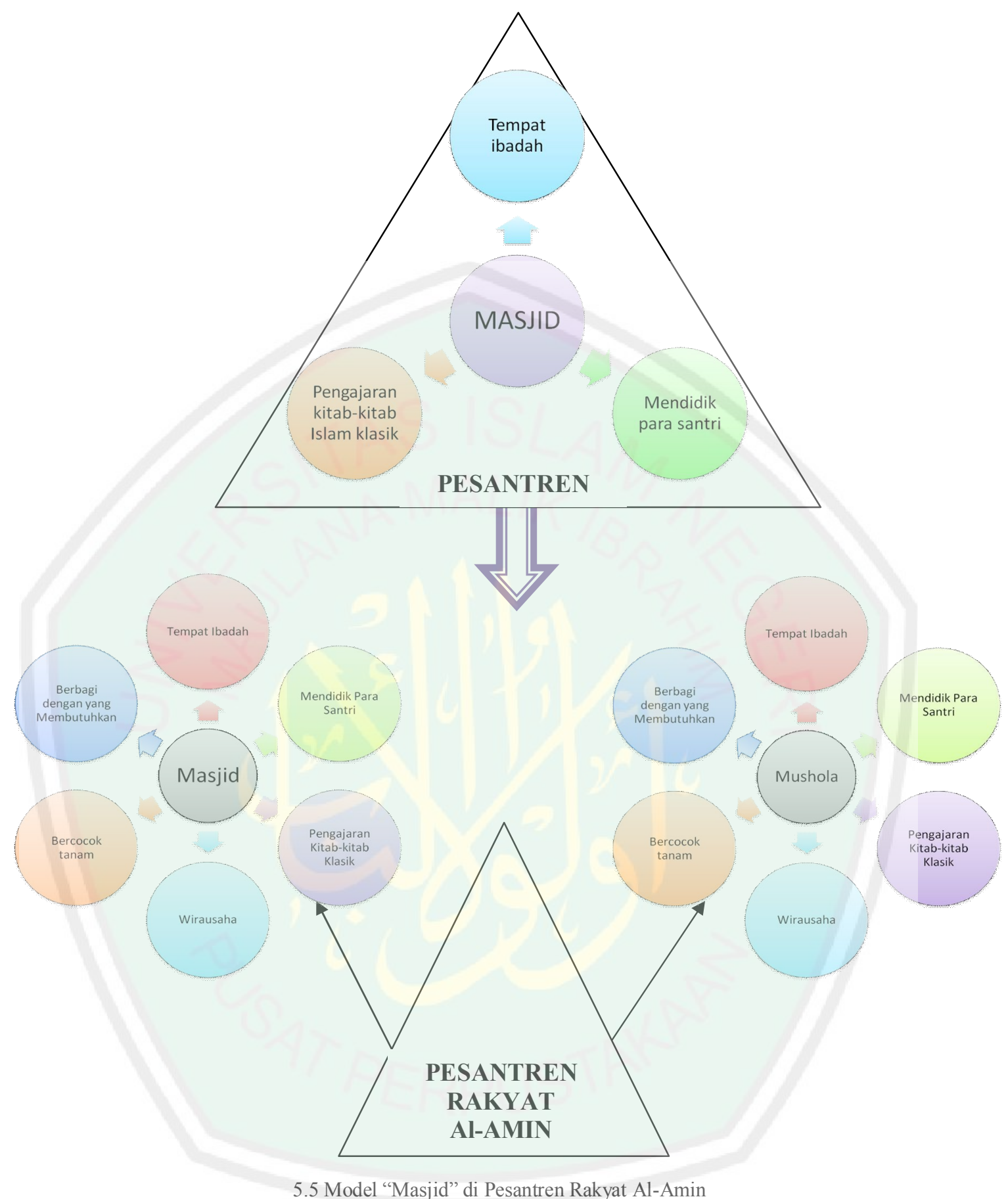

Berdasarkan dari skema di atas terlihat adanya sebuah perbedaan dan pengembangan fungsi masjid di pesantren, yang mana masjid merupakan komponen yang tidak bisa dipisahkan dengan pesantren pada umumnya, lain halnya dengan pesantren rakyat, tidak mempunyai bangunan masjid, justru memanfaatkan dan meramaikan masjid dan 
mushola di sekitar pesantren, dan adanya pengembangan fungsi masjid yang terjadi di Pesantren Rakyat diantaranya, berwirausaha, bercocok tanam dan berbagi rizqi dengan orang yang membutuhkan bagi orang yang mampu.

\section{Pengajaran Kitab-kitab Islam Klasik}

Pengajaran kitab-kitab Islam klasik di pesantren sesungguhnya merupakan upaya memelihara dan mentransfer literatur-literatur Islam klasik yang lazim disebut kitab kuning dari generasi ke generasi selama beberapa abad. Menurut Abdurrahman Wahid, pengajaran kitab-kitab Islam klasik oleh pesantren dijadikan sebagai sarana untuk membekali para santri dengan pemahaman warisan keilmuan Islam masa lampau atau jalan kebenaran menuju kesadaran esoterik ihwal status penghambaan ('ubūdiyah) dihadapan Tuhan, bahkan juga dengan tugas-tugas masa depan dalam kehidupan masyarakat. ${ }^{5}$

Oleh sebab itu, pesantren bertugas untuk mencetak manusia yang benar-benar ahli dalam bidang agama dan ilmu pengetahuan kemasyarakatan serta berakhlak mulia. Untuk mencapai tujuan tersebut maka pesantren mengajarkan Tauhid, Fiqh, Tafsir, Hadits, Nahwu, Sharaf, Ma'ani, Badi' dan Bayan, Ushul al-Fiqh, Musthalah al-hadits, dan Mantiq. ${ }^{6}$ Sedangkan metode yang lazim digunakan dalam pembelajaran kitab-kitab Islam klasik di pesantren adalah sorogan dan wetonan. Metode sorogan adalah metode pembelajaran kitab secara individual, dimana setiap santri menghadap secara bergiliran kepada kiai atau pembantunya,

\footnotetext{
${ }^{5}$ Abdurrahman Wahid, Op,.Cit, hlm. 16-17

${ }^{6}$ Ridlwan Nasir.,Op,.Cit. hlm. 310-311
} 
untuk membaca, menjelaskan, atau menghafal pelajaran yang diberikan sebelumnya. ${ }^{7}$ Dengan metode ini kiai mengetahui betul kemampuan para santrinya.

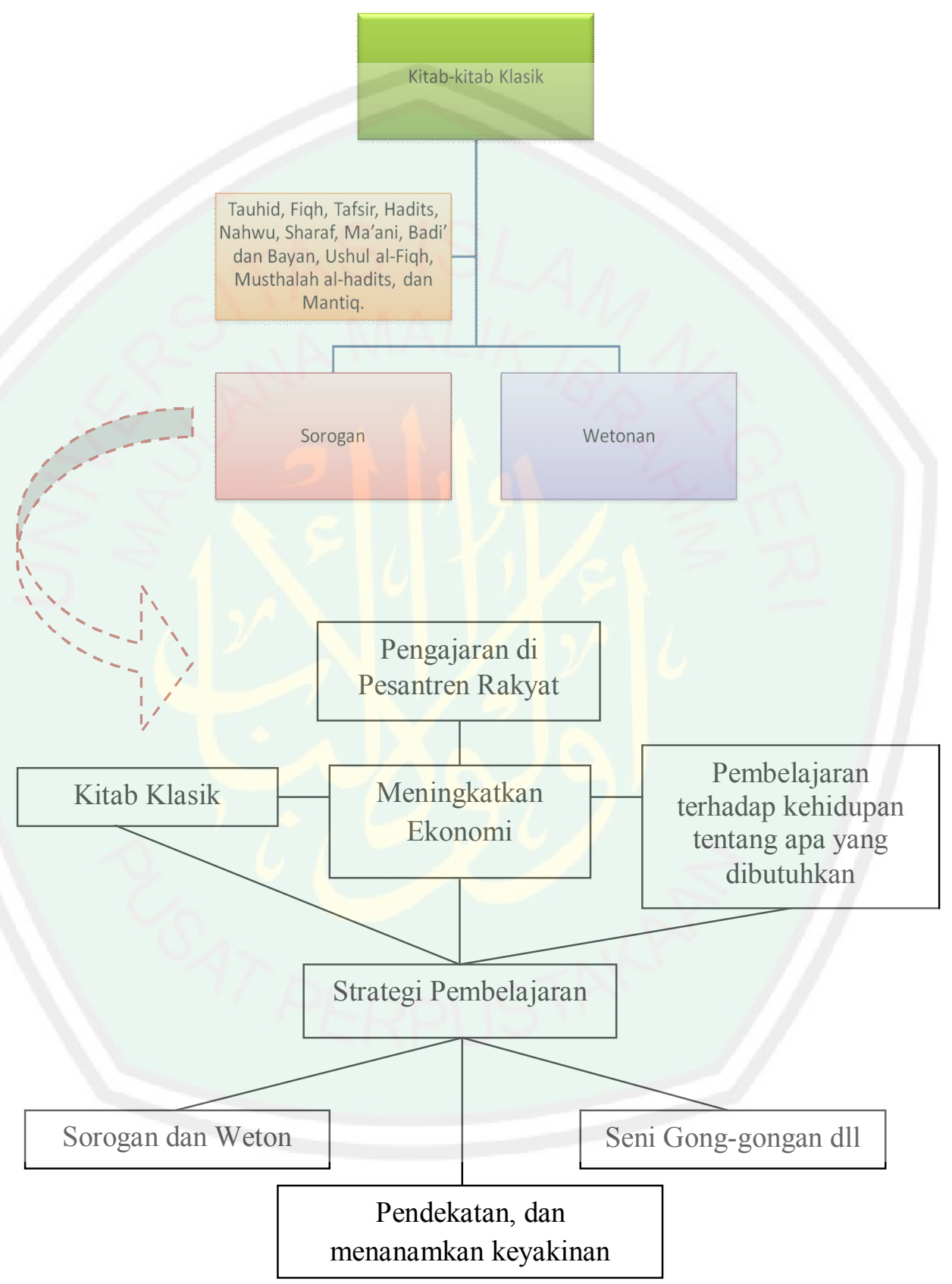

Skema 5.6 Model "Pengajaran Kitab Klasik" di Pesantren Rakyat Al-Amin

${ }^{7}$ Nurcholish Madjid,. Bilik-bilik Pesantren. Op,.Cit. hlm. 28 
Dari skema di atas menggambarkan bahwa Pesantren Rakyat juga mengajarkan kitab-kitab Islam klasik, namun melihat santri yang sangat plural, pesantren ini juga mengajarkan bagaimana meningkatkan ekonomi dan belajar dari kehidupan tentang apa yang dibutuhkan. Pada umumnya pesantren menggunakan metode pembelajaran sorogan dan bandongan, lain lagi dengan pesantren rakyat yang menggunakan strategi pendekatan dan memberi penguatan keyakinan atas potensi yang dimiliki santri, potensi tersebut dikembangkan sesuai dengan kemampuan yang mereka miliki, strategi ini biasa dikenal dengan metode multi strategic. Sedangkan strategi melalui gong-gongan yang dikenal dengan jagong maton Pesantren Rakyat. Jika dilihat dari ciri-ciri strategi, pesantren ini mengadaptasi strategi para wali, khususnya Sunan Kalijaga dalam berdakwah menyebarkan agama Islam di tanah jawa.

Sunan Kalijaga melakukan dakwah melalui kekuatan budaya jagongan, gamelan yang dimodifikasi dan tembang-tembang bermuatan filosofis dan hikmah kehidupan, seperti sya'ir puji-pujian pesantren, kemiripan ini terdapat pada aktivitas jagong maton dengan simbol tradisi jawa, jargon-jargon yang bermakna dengan membentuk karakter para santri. Proses kegiatannya juga diawali dengan tembang, syi'ir, obrolan kemudian informasi yang disisipi dengan penanaman nilai-nilai Islam ala kerakyatan yang mudah dicerna bagi kalangan awam. 


\section{Santri}

Santri merupakan siswa yang menetap di pesantren dimana kiai tinggal, dengan tujuan untuk memperdalam kitab-kitab Islam klasik yang diajarkan oleh kiai. ${ }^{8}$ kita mengenal pembagian macam-macam santri sesuai dengan tradisi pesantren yaitu santri muqim dan santri kalong, sedangkan berdasarkan nilai menurut suteha bahwa santri di bagi menjadi 3 diantaranya santri konservatif, revormatif dan transformative. ${ }^{9}$

Lain halnya di Pesantren Rakyat Sumberpucung, santri adalah siapa saja yang mengaku rakyat dan mau untuk mengaji, baik mengaji kitab klasik maupun mengaji tentang kehidupan meke a good change to be better (mau membuat perubahan yang baik untuk menjadi lebih baik), santri ini berprilaku lokal namun berwawasan global, dalam hal ini slogan santri di Pesantren rakyat "kita yang belajar, kita yang mengajar dan kita yang member gelar". Sedangkan santri yang belajar di pesantren ini tidak ada batasan usia, mulai dari anak-anak sampai lansia, dari kalangan alit sampai kalangan elit, selama orang tersebut mau belajar maka dinamakan santri. Sedangkan pembagian santri di pesantren ini terdiri dari 3 macam santri yakni santri inti, santri kalong dan santri pendukung. Dinamakan santri inti karena santri sewajarnya pondok pesantren pada umumnya, dan santri yang belajar kitab selayaknya santri di pesantren salafiyah. Santri kalong merupakan santri yang datang ke pesantren di saat mengaji saja,

\footnotetext{
${ }^{8}$ Nurcholish Madjid,. Op..Cit, hlm. 20

${ }^{9}$ Zamakhsyari Dhofier, Op..Cit, hlm. 53

${ }^{9}$ Suteja, Op.,cit. hlm. 77
} 
selebihkan kembali ke rumah masing-masing dan yang terakhir adalah santri pendukung dimana santri ini terdiri dari semua orang yang mengaku rakyat, mulai dari kalangan alit sampai kalang elit, dari kalangan korak sampai kalangan qori', wajah boleh preman tetapi hati tetap ka'bah. Keterangan di atas dapat dilihat dari skema di bawah ini:

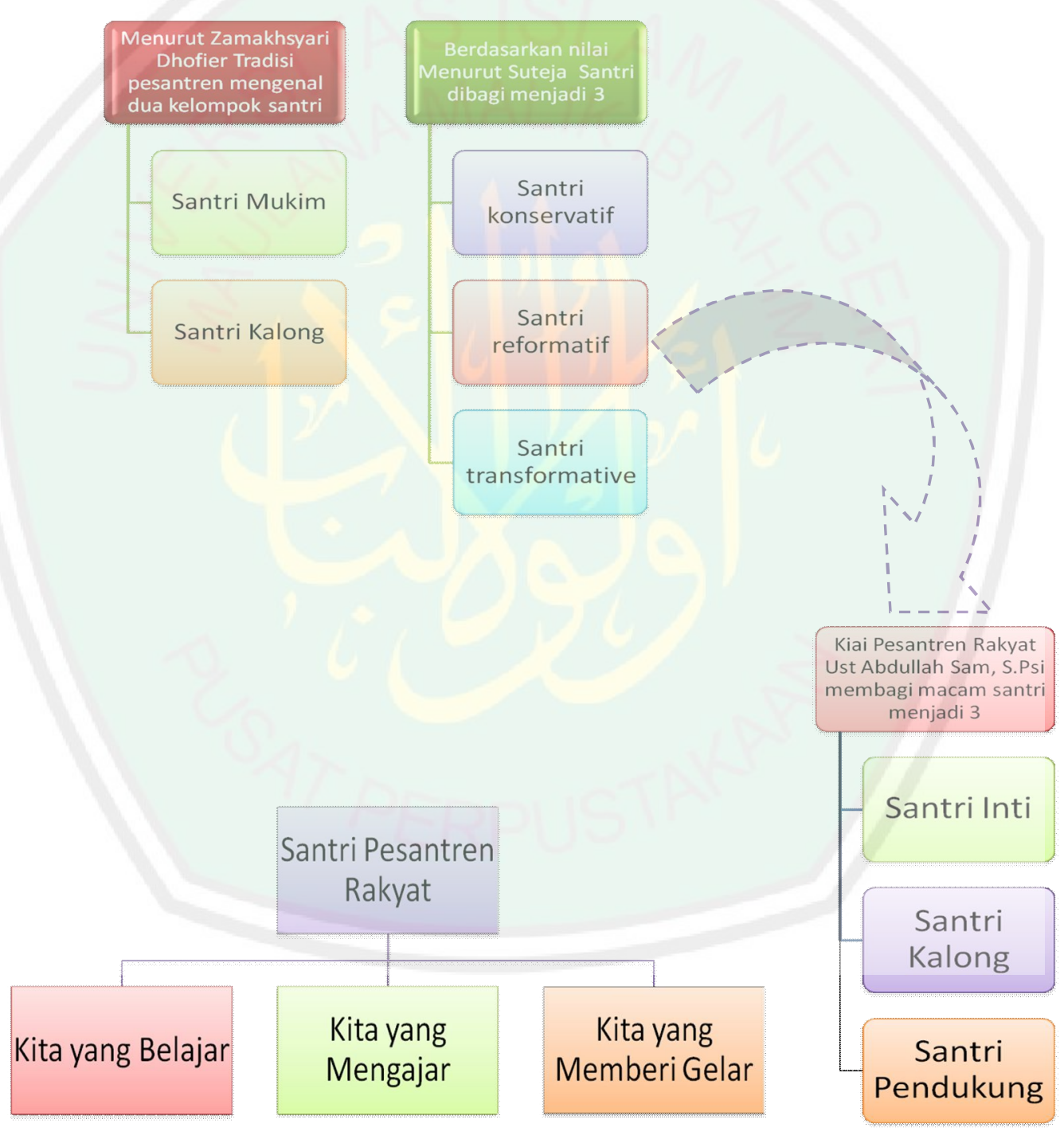

Skema 5.7 Model “Santri” Pesantren Rakyat Al-Amin 


\section{Kiai}

Kiai merupakan sosok sentral yang memangku dan memantau perkembangan sebuah pesantren, selain kiai menjadi pendiri pesantren kiai sekaligus juga sebagai pemilik pesantren. Karena itu, kiranya logis jika dikatakan bahwa perkembangan pesantren sangat tergantung kepada para kiai selaku pendiri dan pemilik pesantren. Keberadaan seorang kiai dalam lingkungan sebuah pesantren laksana jantung bagi kehidupan manusia. Intensitas kiai memperlihatkan peran yang otoriter disebabkan karena kiailah perintis, pendiri, pengelola, pengasuh, pemimpin, dan bahkan juga pemilik tunggal sebuah pesantren.

Lain hal nya di Pesantren Rakyat, kiai pesantren rakyat bukan menjadi sesosok pemimpin yang otoriter namun bersifat demokratis serta tidak pernah memperlihatkan ke-kiai-annya, bersifat luwes dan selalu terbuka dengan siapapun. Beliau bisa menjadi seorang sahabat, sosok kepemimpinan yang selalu bisa membuat orang sekitarnya senang, mampu mengayomi semua santri yang ada, serta mampu menjadi figur inspiratif bagi santrinya. Sebagaimana yang digambarkan pada skema di bawah ini. 

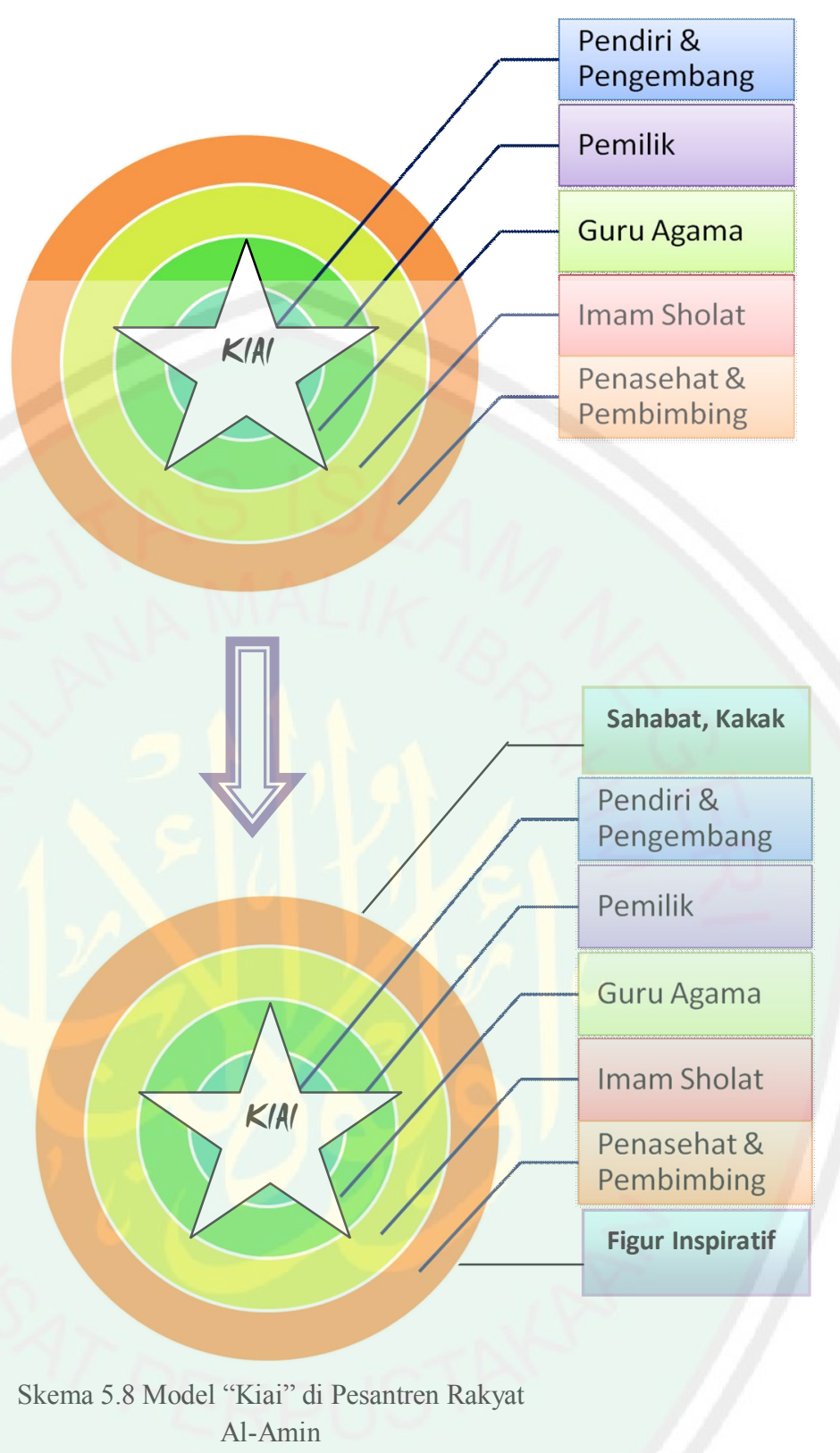

Dari hasil observasi, wawancara dan dokumentasi, serta hasil analisis pesantren Rakyat jika dikategorikan dalam tipologi pesantren, pesantren ini terkategorikan sebagai pesantren campuran antara salaf dan modern, hal ini bisa dilihat dari salah satu strategi pembelajaran yang dilakukan di Pesantren Rakyat yaitu dengan sorogan dan bandongan layaknya pesantren salaf namun di pesantren ini juga menfasilitasi adanya pendidikan formal layaknya pesantren 
modern, begitu juga jika dilihat dari kemampuan santri dan materi yang di pelajari santri, menunjukkan adanya cirri-ciri dari santri salaf dan juga santri modern, namun ada beberapa komponen pembeda, diantaranya dalam pelaksanaan sistem yang ada, jika di pesantren pada umumnya pembelajaran bersifat sentral dan semua santri mendapatkan pelajaran yang sama, lain halnya dengan Pesantren Rakyat yang lebih membebaskan santrinya untuk memilih bakat dan minat sesuai dengan kemampuan yang mereka miliki, sehingga santri yang belajar di Pesantren Rakyat mampu dalam bidang yang mereka minati dan bakati, sebagai contoh ada santri yang pandai di bidang kitab Islam klasik layaknya di pesantren salaf, begitu juga bidang bahasa, sebagai karakteristik dari pesantren modern. 


\section{BAB VI}

\section{PENUTUP}

Bab VI ini sebagai penutup yang memuat kesimpulan dan saran. Kesimpulan dan saran adalah temuan-temuan penelitian yang berdasarkan paparan data mengenai sistem pengembangan pendidikan Pesantren Rakyat di Sumberpucung Kabupaten Malang.

\section{A. Kesimpulan}

Berdasarkan hasil penelitian tentang model Pesantren Rakyat Al-Amin di Sumberpucung Kabupaten Malang, dapat ditarik kesimpulan sebagai berikut: bahwa Model Pesantren Rakyat Sumberpucung Kabupaten Malang merupakan pesantren yang berbasis rakyat, dimana kegiatan yang dilaksanakan langsung bercampur dengan masyarakat, bahkan tempatnya pun menggunakan istilah gedung alam. Di manapun dan kapanpun kaki berpijak disitu akan mendapatkan ilmu, belajar dan menuntut ilmu. Pesantren ini tidak memiliki tempat khusus mulai dari masjid, pondok, dll. Akan tetapi, memiliki sistem pembelajaran yang unik, setiap santri mendapatkan sistem pembelajaran yang berbeda karena latar belakang santri yang bermacam-macam, mulai dari kalangan pejabat sampai orang mlarat, dari orang-orang korak sampai ada yang qori', serta semua orang yang mengaku rakyat disebut santri pesantren ini, hal inilah yang menjadi perbedaan dengan pesantren-pesantren lainnya.

Pesantren Rakyat tetap memiliki komponen Pesantren sesuai dengan teori yang ada namun mempunyai perbedaan dalam sistem pengembangan komponen tersebut. Pesantren Rakyat pelakunya seluruh rakyat yang beragama 
Islam yang mau mengerti atau melaksanakan nilai-nilai universal Islam yang tetap wajib di bawah naungan dan izin Ulama', Pelaksanaan kegiatan di Pesantren Rakyat terjadi kapanpun, asal kesadaran dakwah islamiyah muncul pada pribadi setiap muslim.

Pesantren Rakyat tidak mementingkan sebuah bangunan, santri yang belajar tidak terbatas di kelas layaknya pesantren pada umumnya, ruang belajar santri Pesantren Rakyat bisa di mana saja (forum mahasiswa, pemuda, tahlilan, rutinan, seminar, sarasehan, cangkruan, warung kopi, masjid musholla/surau, pasar, stasiun, sawah, pabrik, kantor d1l), adanya sebuah strategi dan metode unik ala rakyat ini adalah perlunya membumikan kepada masyarakat luas, nilai-nilai universal Islam yang luas dan luwes sehingga dapat menembus segala sisi-sisi kehidupan rakyat (di mana sekarang jarak antara da'i/da'iah dan masyarakat mulai tampak). Aktifitas atau kegiatan rakyat berbagai tingkat usia, latar belakang, budaya, kepentingan, pendidikan yang termodifikasi dan di tumpangi dengan nilai-nilai ke Indonesiaan dan keIslaman yang kurikulumnya ala rakyat dan sinergi dengan kebutuhan rakyat dengan memasukkan nilai-nilai universal Islam yang gampang, ringan/murah, luas dan luwes kepada semua aktifitas rakyat sehingga Islam tidak di anggap harus berbentuk lembaga, dan simbol yang menakutkan.

Berbeda dengan pesantren konvensional yang pelakunya adalah kiai, gus atau setidaknya alumni pondok pesantren yang ahli kitab kuning/al-Qur'an. Kegiatan dilaksanakan menunggu maksimal ilmu pondok pesantrennya dan hanya di lingkungan pondok pesantren, semua ini karena perlunya pemahaman agama secara maksimal kepada santri dan masyarakat baik tataran ilmu 
syari'at, thoriqat, hakikat dan ma'rifatnya (al-qur'an, hadits, kitab-kitab kuning serta ilmu-ilmu alatnya, biasanya lembaga pendidikan agama seperti pondok pesantren pada umumnya berbentuk formal dan kurikulumnya sudah baku di tentukan oleh pondok pesantren sehingga semua yang bergabung di pondok pesantren harus seragam materinya dengan tujuan mencetak santri sesuai dengan visi, misi, tujuan, jargon dari pondok pesantrennya yaitu ahli al-Qur'an, kitab kuning, tafsir, fiqih, dan juga bahasa.

B. Saran

Menyadari urgensi model Pesantren Rakyat Al-Amin Sumberpucung Kabupaten Malang, berdasarkan temuan penelitian dan kesimpulan, terdapat beberapa saran yang ingin peneliti sampaikan. Berkenaan dengan model pesantren, untuk Pesantren Rakyat Al-Amin agar meningkatkan kerjasama dengan pesantren yang lainnya, agar pesantren lainnya mampu membuka peluang pembelajaran bagi semuanya tanpa terkecuali dan tanpa pandang bulu seperti halnya Pesantren Rakyat, namun terlepas dari itu semua Pesantren Rakyat Al-Amin juga diharapkan dapat melakukan evaluasi sejauh mana model yang ada ini mampu mewujudkan visi, misi dan tujuan yang ada. 


\section{DAFTAR PUSTAKA}

Ahmadi, Rulam. 2005. Memahami Metodologi Penelitian Kualitatif (Malang: UIN Malang Press)

Al-Abrasyi, M. Athiyan. 1993. Dasar-dasar Pokok Pendidikan Islam, terj. Bustami A. Gani dan Djohar Bahry, LIS., cet. ke-7 (Jakarta: Bulan Bintang)

Ali, A. Mukti. 1981. Beberapa Persoalan Agama Dewasa Ini, cet. ke-1 (Jakarta: Rajawali Press)

Aly, Abdullah. 2011. Pendidikan Islam Multikultural di Pesantren (Yogyakarta: Pustaka Pelajar)

Amirin, M. Tatang. 1986. Pokok-pokok Teori Sistem (Jakarta: Rajawali)

Amsyari, Fuad. 1986. keharmonisan Lingkunga $n$ sebagai Determinan Keberhasilan Pembangunan Pendidikan: Suatu Analisis dari Pandangan Islam (Surabaya: Indah Offset, IAIN Sunan Ampel)

Azra, Azyumardi. 2003. Surau: Pendidikan Islam Tradisional dalam Tradisi dan Modernisasi (Jakarta: Logos)

"Masalah dan Kebijakan Pendidikan Islam di Era Otonomi Daerah" makalah disampaikan pada Konferensi Nasional Manajemen Pendidikan di Hotel Indonesia, Jakarta 8-10 Agustus 2002, kerja sama Universitas Negeri Jakarta dengan Himpunan Sarjana Administrasi Pendidikan Indonesia.

Bawani, Imam. 1993. Tradisionalisme dalam Pendidikan Islam, cet. ke-1 (Surabaya: al-Ikhlas)

2011. Pesantren Buruh Pabrik, Pemberdayaan Buruh Pabrik Basis Pendidikan Pesantren (Yogyakarta: LKIS)

Bil Rami, Hamid Hasan dan Sayid Ali Asyraf. 1989. Konsep Universitas Islam, terj. Machnun Husein, cet. ke-1, (Yogyakarta: Tiara Wacana Yogya)

Bungin, Burhan. 2007. Penelitian Kualitatif, (Jakarta: Kencana)

----------. 2007. Metodologi Penelitian Kualitatif Aktualisasi Metodologis ke Arah Ragam Varian Kontempoter (Jakarta: Raja Grafindo Persada)

Creswell, John W. 1998. Qualitative Inquiry and Research Design; Choosing Among Five Traditions (Thousand Oaks, CA: Sage) 
Dhofier, Zamakhsyari. 1994 Tradisi Pesantren: Studi tentang Pandangan Hidup Kiai (Jakarta: LP3ES)

Geertz, Clifford. 1983. Abangan Santri, Priyayi dalam Masyarakat jawa, terj. Aswab Mahasin (Judul asli: The Religion Of Java), cet. ke-2, (Jakarta: Dunia Pustaka Jaya)

Hamidi. 2005. Metode Penelitian Kualitatif Aplikasi Praktis Pembuatan Proposal dan Laporan Penelitian (Malang: UMM Press)

Hasbullah. 1996. Kapita Selekta Pendidikan Islam, cet. Ke-1, (Jakarta: Raja Grafindo Persada)

- 1996. Sejarah Pendidikan Islam di Indonesia, Lintasan Sejarah Pertumbuhan dan Perkembangan, cet. ke-2, (Jakarta: raja Grafindo Persada)

Jacub, H M. 1981. Pondok Pesantren dan Pengembangan Masyarakat Desa (Bandung: Angkasa)

Jalaluddin dan Usman Said. 1996. Filsafat Pendidikan Islam Konsep dan Perkembangan, cet. ke-2 (Jakarta: Raja Grafindo Persada)

Kantaprawira, Rusadi. 1987. Aplikasi Pendekatan Sistem dalam Ilmu-ilmu Sosial (Jakarta: Bunda Karya)

Langgulung, Hasan. 1992. Asas-asas Pendidikan Islam, cet. ke-2 (Jakarta: Mutiara Sumber Widia)

L.A, Zul Asyri. 1990. Nahdhatul Ulama Studi tentang Paham Keagamaan dan Upaya Pelestarianny Melalui Lembaga Pendidikan Pesantren, Disertasi (Jakarta: IAIN Syarif Hidayatullah)

Madjid, Nurcholish. "Merumuskan Kembali Tujuan Pendidikan Islam" dalam Dawam Rahardjo, (ed). 1985. Pergulatan Dunia Pesantren, Membangun dari Bawah (Jakarta: P3M)

-----------. 1992. Islam Doktrin dan Peradaban, Sebuah Telaah Kritis Tentang Masalah Keimanan, Kemanusiaan dan Kemodernan, cet. Ke-2 (Jakarta: Paramadina)

1997. Bilik-bilik pesantren Sebuah potret Perjalanan (Jakarta: Paramadina.

1997. Kaki Langit Peradaban Islam, cet. ke-1 (Jakarta: Paramadina)

1997. Tradisi Islam, Peran dan Fungsinya Dalam Pembangunan di Indonesia, cet. ke-1 (Jakarta: Paramadina) 
1998. Dialog Keterbukaan, Artikulasi Nilai-nilai Islam dalam Wacana Sosial Politik Kontemporer, cet. ke-1 (Jakarta: Paramadina)

1999. Republika. Untuk Menguasai MIPA Lembaga Pendidikan Islam Mesti Memodernisasi Diri. Senin, 8 Maret

Margono, S. 2007. Metodologi Penelitian Pendidikan (Jakarta: PT Rineka Cipta)

Miles, Matthew B. dan A. Michael Huberman. 1992 Analisis Data Kualitatif (Penerjemah: Tjetjep Rohendi Rohidi). (Jakarta: UI-Press)

Moleong,Lexy J. 2005. Metode Penelitian Kualitatif (Bandung: PT Remaja Rosdakarya) 2006. Metode Penelitian Kualitatif (Bandung: PT Remaja
Rosdakarya) 2007. Metodelogi Penelitian Kualitatif (Bandung: PT Remaja Rosdakarya)

Mufidah, Ch. 2012. Pesantren Rakyat (el harakah Vol.14 No1)

Mulkhan, Abdul Munir. 1994. Runtuhnya Mitos Politik Santri, Strategi Kebudayaan dalam Islam, cet. ke-1, (Yogyakarta: Sipress)

Musnamar, Tohari. 1985. Bimbingan dan Wawanwuruk sebagai Suatu Sistem (Yogyakarta: Cendikia Sarana Informatika)

Nasir, Ridlwan 2005. Mencari Tipologi Format Pendidikan Ideal (Yogyakarta: Pustaka Pelajar)

Nawawi, Hadari dan Mimi Martini. 1994. Penelitian terapan (Yogyakarta: Gajah Mada University Press)

Qutub, Muhammad. 1984. Sistem Pendidikan Islam, Alih Bahasa Salman Harun, (Bandung: al-Ma'arif)

S, Lincoln Y and A.G. Guba. Naturalistic Inquiry (Beverly Hils: Sago Publication, 1985),

Saliman dan Sudarsono. 1994. Kamus Pendidikan, Pengajaran dan Umum, cet. ke-1, (Jakarta: Rineka Cipta)

Siraj, Sa'id Aqiel. 1999. Pesantren Masa Depan: Wacana Pemberdayaan dan Transformasi Pesantren (Bandung: Pustaka Hidayah)

Stake, Robert E. 1994. "Case Studies", dalam Norman K. Denzin \& Yvonna S. Lincoln (ed.), Handbook of Qualitative Research (London: Sage Publications) 
Streenbrink, Karel A. 1996. Pesantren Madrasah Sekolah, Pendidikan Islam Dalam Kurun Modern (Jakarta: LP3ES)

Sukmadinata, Nana Syaodih. 2007. Metode Penelitian Pendidikan (Bandung: Remaja Rosdakarya)

Supeno, Hadi. 1999. Pendidikan Dalam Belenggu Kekuasaan, Cet. I (Magelang: Pustaka Paramedia).

Suyata. Community Participation in school Development: Acces, Demand, and School Contruction (Jakarta: Directorate of Seconday Education, Directorate General of Primay and Secondary Education, Ministry of Education and Culture, 1996).

Tim Penyusun. 1989. Kamus Besar Bahasa Indonesia, cet. ke-2, (Jakarta: Balai Pustaka)

Tim Penyusun Kamus Bahasa Indonesia. 2008. Kamus Bahasa Indonesia (Jakarta: Pusat Bahasa Departemen Pendidikan Nasional)

Tim Penyusun. 1992. Ensklopedi Islam Indonesia (Jakarta: Djambatan)

Wahidmurni. 2008. Cara Mudah Menulis Proposal dan Laporan Penelitian Lapangan (Malang: UM Press)

Wahid, Abdurrahman, dkk. 1988. Pesantren dan Pembaharuan (Jakarta: LP3ES)

Yasmadi. 2002. Modernisasi Pesantren, Kritik nurcholish Madjid Terhadap Pendidikan Islam Tradisional (Jakarta: Ciputat Press)

Ziemek, Manfred. 1986. Pesantren dalam Perubahan Sosial (Jakarta: P3M)

Surakhmad, Winarno. Kembalikan pendidikan Pada Masyarakat. Dalam http://www.kompas.com/kompas\%2Dcetak/0111/20/dikbud/kemb09.ht $\mathrm{m}$. berita ini dimuat dalam harian kompas 20 November 2001. (diakses 10 April 2013)

Sambutan Ust Abdullah Sam, S.Psi (Pengasuh Pesantren Rakyat). Malang, Rabu 25 Juni 2008

Pesantren Rakyat. Pesantren Rakyat. http://pesantrenrakyat.blogspot.com/ (diakses 9 Januari 2013) 